\title{
CARACTERÍSTICAS MORFOGÊNICAS E PADRÕES DE DESFOLHAÇÃO EM PASTOS DE CAPIM MARANDU SUBMETIDOS A REGIMES DE LOTAÇÃO CONTÍNUA
}

\section{ALEXANDRE DE CAMPOS GONÇALVES}

Dissertação apresentada à Escola Superior de Agricultura "Luiz de Queiroz", Universidade de São Paulo, para obtenção do título de Mestre em Agronomia; Área de concentração: Ciência Animal e Pastagens.

\author{
PIRACICABA \\ Estado de São Paulo - Brasil \\ Novembro - 2002
}




\title{
CARACTERÍSTICAS MORFOGÊNICAS E PADRÕES DE DESFOLHAÇÃO EM PASTOS DE CAPIM MARANDU SUBMETIDOS A REGIMES DE LOTAÇÃO CONTÍNUA
}

\section{ALEXANDRE DE CAMPOS GONÇALVES}

Engenheiro Agrônomo

Orientador: Prof. Dr. SILA CARNEIRO DA SILVA

\begin{abstract}
Dissertação apresentada à Escola Superior de Agricultura "Luiz de Queiroz", Universidade de São Paulo, para obtenção do título de Mestre em Agronomia; Área de concentração: Ciência Animal e Pastagens.
\end{abstract}

\author{
PIRACICABA \\ Estado de São Paulo - Brasil \\ Novembro - 2002
}




\section{Dados Internacionais de Catalogação na Publicação (CIP) DIVISÃO DE BIBLIOTECA E DOCUMENTAÇ̃̃O - ESALQ/USP}

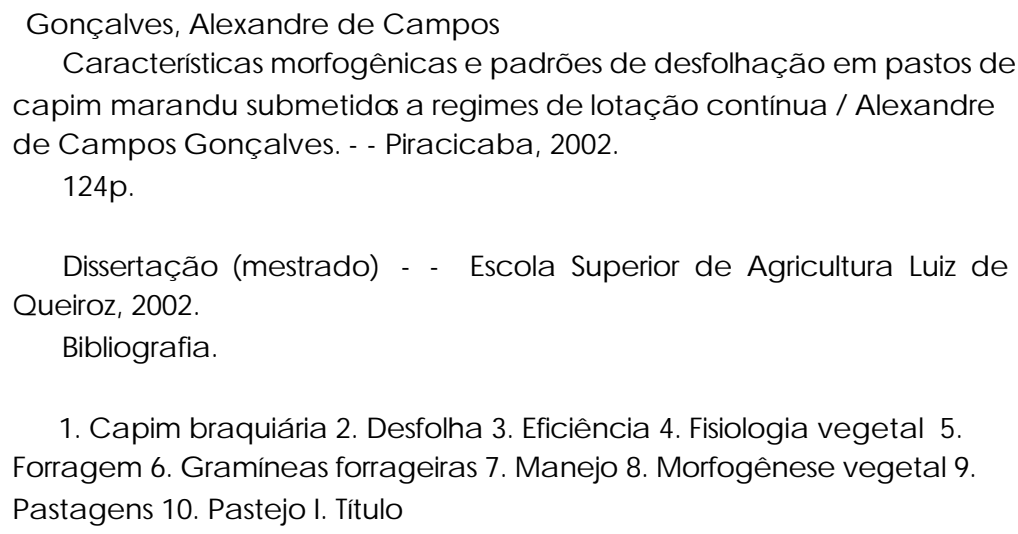

1. Capim braquiánia 2. Desfolha 3. Eficiência 4. Fisiologia vegetal 5. Forragem 6. Gramíneas forrageiras 7. Manejo 8. Morfogênese vegetal 9. Pastagens 10. Pastejo I. Título 
A minha adorável esposa Fabianna,

por dar cor e brilho a minha vida.

Dedico 
Aos meus amados pais Gilberto e Maria Helena,

pelo exemplo impar e dedicação na construção de meu caráter.

Aos meus queridos irmãos Paulo e Heloisa,

pelo amor, carinho e incentivo em minhas empreitadas,

mesmo nas mais absurdas.

Ao grande amigo Paulo José Araripe Costa, pela contribuição e apoio nessa atribulada etapa da vida.

Aos meus queridos afilhados Victor Giro e Leonardo Sarkis e a seus pais, e a minha doce sobrinha Isabela, pelo extraordinário significado que tem em minha vida. 
"A verdadeira viagem de descobrimento não consiste em buscar novas paisagens, mas em ter novos olhos".

Marcel Proust (1871-1922) 


\section{Agradecimentos}

A USP/ESALQ, através do Departamento de Zootecnia pelo privilégio e oportunidade de retornar para realização do curso de Mestrado.

Ao Professor Dr. Sila Carneiro da Silva, pela confiança e oportunidade impar de desenvolver esse trabalho de pesquisa, pela maestria com que executou seu papel de orientador contribuindo para qualidade final desta dissertação e, acima de tudo, pela amizade desenvolvida ao longo desses anos de trabalho.

A todos os Professores do Departamento de Zootecnia e, em especial, ao Professor Dr. Cláudio Maluf Haddad, pelo exemplo pessoal e profissional, apoio, amizade e confiança, e pelas diversas e valiosas sugestões.

Aos professores Dr. John Hodgson e Dr. Cory Matthew (Massey University, Palmerston North, Nova Zelândia), e ao professor Michael Hugh Wade (Facultad de Ciencias Veterinarias, UNCPBA, Tandil, Argentina) pelas sugestões para elaboração deste trabalho, e apoio na discussão dos resultados aqui apresentados.

Aos grandes amigos e companheiros de trabalho, Waldeliza Ferreira da Cunha, Daniel de Oliveira Sarmento, Adriano Luppinacci Vecchiatti, Flávia Maria Erberta de Andrade e Leonardo Kehdi Molan, que se dedicaram de corpo e alma ao enorme trabalho de produção dos dados aqui relatados e, em especial, ao amigo André Fischer Sbrissia que também prestou inestimável ajuda com a elaboração das planilhas eletrônicas para os cálculos dos dados trabalhados.

Aos verdadeiros heróis na implantação da área experimental e na coleta dos dados para esse trabalho, os estagiários e amigos, Alexandra Lupo (Soqt), Alexandre Marino (Volvo), Artur Siqueira (Mula), Cauê Zeferino (Juruna), Daniel Perissinoto (Pinoxê), Daniela de Oliveira (Sedem), Danilo Kashiwakuara (Pik-fina), Diego da Silva (Novilho), Eduardo Ribeiro (Montanha), Érica Nakandare (Kiçaça), Érica Rodrigues (Zaga), Fábio Caminha (7-Foia), Felipe Barreto (Kuatrilho), Lílian Belucci (Xá-d-fita), 
Marcos Calicchio (Abeia), Maurício Nogueira (Di-B-lém), Tatiane Casaroti (Edileuza), Tiago Palma (Tokntins), Victor Hugo (Beta), Vitor Carvalho (Motoboy), Roberto de Camargo (Mirrado), e outros que em algum momento e de alguma forma tenham contribuído nessa empreitada.

A Sra. Sônia Maria Delfini pelo enorme incentivo para que eu desse início a essa nova etapa de minha formação. A Sra. Creide E. Martins pela paciência, bom humor e amizade durante todo o período de execução do trabalho. A Sra. Sílvia Zinsly pela atenção ao corrigir este trabalho adequando-o æ̇ normas de redação científica.

Aos Srs. Jucelino, Emerson, Benedito, Laureano, Carlos, Augusto e demais funcionários do Departamento de Zootecnia da ESALQ/USP, pela amizade e auxílio fundamentais na execução deste trabalho.

A todos os colegas do curso de pós-graduação, dentre eles, Décio Maluf, Dimas Oliveira, Henrique Rocha, João de Deus, José de Lavres, Lívio Andrade, Luiz Bassetti, Patrízia Bricarello, Roberto Wagner (Passarinho) e Rosane Rodrigues, pelos agradáveis momentos de estudo e de descontração.

A meus sogros Marco Antônio e Leonilda Sarkis pela presença constante, apoio e, sobretudo, pela figura exemplar que representam em minha vida pessoal.

Aos meus queridos cunhados Cláudio Augusto, Flávia e Marquinhos pela amizade e companheirismo constantes.

Aos meus fieis companheiros Thobias, Picolé e Barnabé, pelo afeto e dedicação imensuráveis, e a doce Pepita pelo carinho e presença marcantes durante toda a redação deste trabalho, tornando-o mais ameno.

À Coordenadoria de Aperfeiçoamento Pessoal de Nível Superior (CAPES) pela concessão da bolsa de estudos durante parte de meu programa de mestrado. À Fundação de Amparo a Pesquisa do Estado de São Paulo (FAPESP) pelo financiamento das práticas na área experimental.

À PROJEPEC - Projetos \& Consultoria Agropecuária pelo suporte operacional e financeiro para que essa etapa pudesse ser cumprida com sucesso.

$\mathrm{E}$ a todos os demais que de alguma forma tenham colaborado para realização deste trabalho. 


\section{SUMÁRIO}

Página

RESUMO …........................................................................................... x

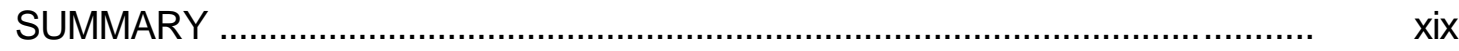

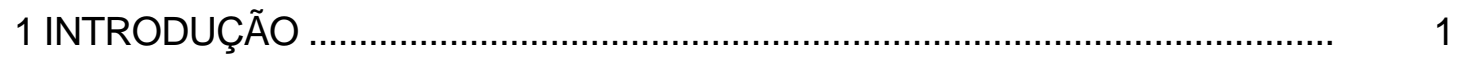

2 REVISÃO DE LITERATURA .................................................................

2.1 - Aspectos de comunidades de plantas forrageiras ......................................... 4

2.1.1 - Unidades básicas das plantas - perfilhos ................................................. 4

2.1.2 - Comunidade de plantas forrageiras - populações de perfilhos .................... 5

2.2 - Morfogênese de plantas forrageiras e estrutura do relvado ............................ 6

2.3 - O processo de acúmulo de forragem em pastagens ..................................... 10

2.4 - Respostas a regimes de desfolhação ......................................................... 13

2.4.1 - Produção de forragem ............................................................................... 13

2.4.2 - Ingestão de forragem pelos animais em pastejo ….................................... 15

2.4.3 - Padrões de desfolhação de perfilhos individuais .......................................... 18

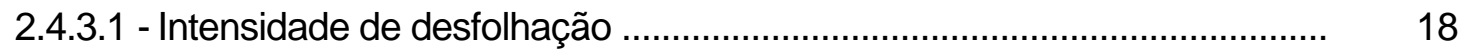

2.4.3.2 - Freqüência de desfolhação ................................................................. 21

2.4.3.3 - Eficiência de pastejo …………………............................................... 24

2.5 - Dinâmica de desfolhação de plantas forrageiras .......................................... 28

3 -MATERIAL E MÉTODOS ...................................................................... 32 


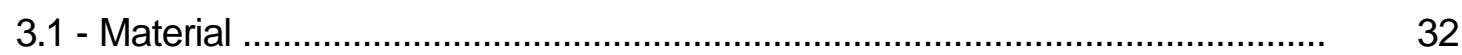

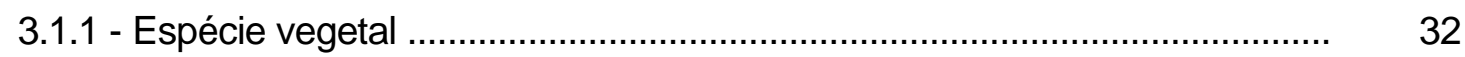

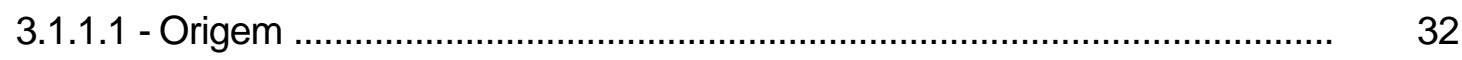

3.1.1.2 - Características gerais ..................................................................... 33

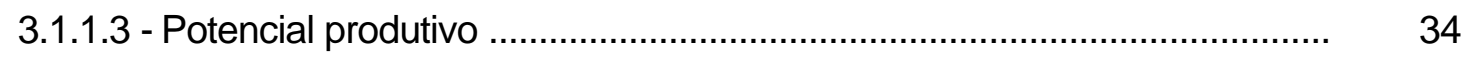

3.1.2 - Local do experimento ......................................................................... 34

3.1.2.1 - Localização geográfica .................................................................... 34

3.1.3 - Solo da área experimental .............................................................. 35

3.1.4 - Clima …................................................................................... 36

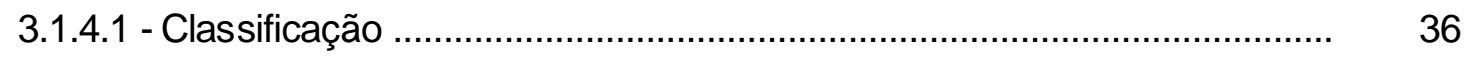

3.1.4.2 - Dados do período de amostragem .................................................. 36

3.1 .5 - Animais ................................................................................ 38

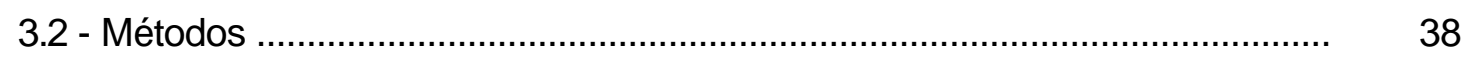

3.2.1 - Delineamento experimental e tratamentos ................................................. 38

3.2.2 - Instalação das condições experimentais ................................................. 39

3.2.2.1 - Semeadura .................................................................................. 39

3.2.2.2 - Controle de plantas daninhas ....................................................... 40

3.2.2.3 - Fertilização e tratos culturais ............................................................ 40

3.2.3 - Monitoramento das condições experimentais .......................................... 41

3.2.3.1 - Alturas dos tratamentos ................................................................ 41

3.2.3.2 - Fertilização e tratos culturais ........................................................... 44

3.2.3.3 - Controle do peso vivo dos animais .................................................... 44

3.2.4 - O período experimental ........................................................................ 45

3.2.5 - Avaliações de campo ..................................................................... 45

3.2.5.1 - Seleção e demarcação de perfilhos .................................................... 45 
3.2.5.2 - Avaliações de campo ………………………………………........ 46

3.2.6 - Avaliações derivadas dos dados de campo .................................................. 47

3.2.6.1 - Taxa de aparecimento de folhas ............................................................ 47

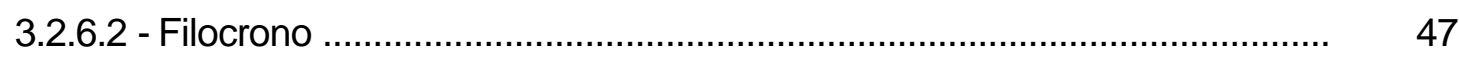

3.2.6.3 - Número de folhas vivas por perfilho ........................................................ 48

3.2.6.4 - Longevidade das folhas ........................................................................... 48

3.2.6.5 - Freqüência de desfolhação ....................................................................... 48

3.2.6.6 - Intensidade de desfolhação ………………………………………….... 49

3.2.6.7 - Eficiência de pastejo ………………………………………………….. 49

3.2.7 - Processamento de dados ...................................................................... 51

3.2.7.1 - Tabulação de dados ........................................................................... 51

3.2.7.2 - Cálculo das médias ................................................................................. 51

3.2.8 - Análise estatística .................................................................................... 51

4 -RESULTADOS E DISCUSSÃO ………………………………………........ 52

4.1 - Características morfogênicas .................................................................... 52

4.1.1 - Taxa de aparecimento de folhas ........................................................... 52

4.1.1.1 - Expresso em no de folhas/perfilho.dia ................................................ 52

4.1.1.2 - Expresso em no de folhas/perfilho.graus-dia ......................................... 55

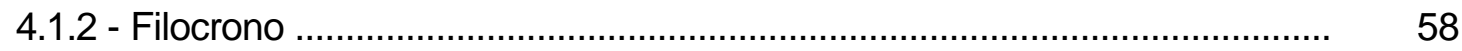

4.1.2.1 - Expresso em dias/folha ......................................................................... 58

4.1.2.2 - Expresso em graus-dia/folha ................................................................. 61

4.1.3 - Número médio de folhas vivas por perfilho ................................................... 63

4.1.4 - Longevidade das folhas ................................................................................. 66

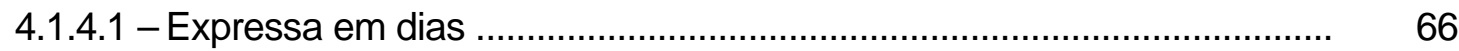

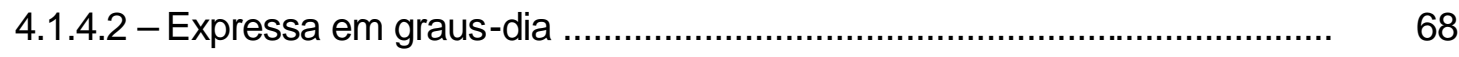


4.2 - Padrões de desfolhação ........................................................................ 71

4.2.1 - Freqüência de desfolhação ................................................................ 71

4.2.1.1 - Freqüência de desfolhação por perfilho …........................................... 72

4.2.1.2 - Freqüência de desfolhação por perfilho estendido ................................. 77

4.2.1.3 - Freqüência de desfolhação por folha ................................................... 81

4.2.1.4 - Freqüência de desfolhação por tipo de folha ......................................... 85

4.2.2 - Intensidade de desfolhação ............................................................ 90

4.2.2.1 - Intensidade de desfolhação por perfilho estendido ................................. 90

4.2.2.2 - Intensidade de desfolhação por folha .................................................. 94

4.2.2.3 - Intensidade de desfolhação por tipo de folha ......................................... 97

4.2.3 - Eficiência de pastejo ......................................................................... 101

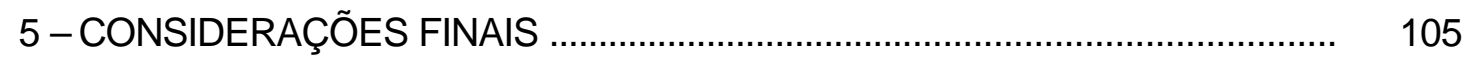

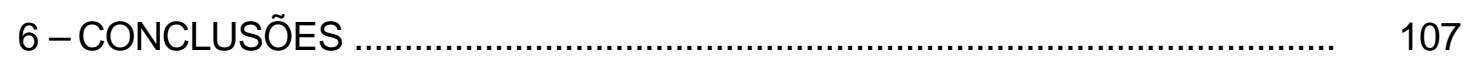

REFERÊNCIAS BIBLIOGRÁFICAS ............................................................... 108 


\title{
CARACTERÍSTICAS MORFOGÊNICAS E \\ PADRÕES DE DESFOLHAÇÃO EM PASTOS DE CAPIM MARANDU SUBMETIDOS A REGIMES DE LOTAÇÃO CONTÍNUA
}

\author{
Autor: ALEXANDRE DE CAMPOS GONÇALVES \\ Orientador: Prof. Dr. SILA CARNEIRO DA SILVA
}

\section{RESUMO}

A carência de conhecimentos específicos sobre a ecofisiologia das plantas forrageiras de clima tropical limita a adequação de estratégias de manejo do pastejo que possibilitem o melhor aproveitamento possível do seu potencial de produção de forragem. Nesse contexto, o presente experimento, conduzido no Departamento de Zootecnia da USP/ESALQ, em Piracicaba, SP, de novembro de 2001 a fevereiro de 2002, teve como objetivo avaliar as características morfogênicas e os padrões de desfolhação em pastagens de Brachiaria brizantha (Hochst ex A. Rich) cultivar Marandu. Os tratamentos corresponderam a quatro alturas de dossel forrageiro (10, 20, 30 e $40 \mathrm{~cm}$ ) mantidas constantes através de pastejo por bovinos em regime de lotação contínua com taxa de lotação variável. O delineamento experimental utilizado foi o de blocos completos casualizados, com quatro repetições. Foram avaliadas as seguintes respostas: (1) características morfogênicas: taxa de aparecimento de folhas (TAF), filocrono, número de folhas vivas por perfilho e longevidade de folhas; e (2) padrões de desfolhação de perfilhos individuais: freqüência e intensidade de desfolhação e eficiência de pastejo (utilização). Pastos mantidos a $10 \mathrm{~cm}$ 
apresentaram maior TAF (0,12 folha/perfilho.dia e 0,012 folha/perfilho.graus-dia) e menor filocrono (9,0 dias/folha e 84,8 graus-dia/folha) que aqueles mantidos a 20, $30 \mathrm{e}$ $40 \mathrm{~cm}(0,11,0,10,0,10$ folha/perfilho.dia e $0,011,0,011,0,010$ folha/perfilho.graus-dia; $10,3,10,3,10,9$ dias/folha e 95,1,95,1, 100,6 graus-dia/folha, respectivamente), os quais não diferiram entre si $(P \geq 0,10)$. A longevidade de folhas acompanhou os resultados de filocrono $(34,4,43,1,45,5,48,4$ dias/folha e 332,1, 441,6, 433,5, 462,0 graus-dia/folha para 10, 20, 30 e $40 \mathrm{~cm}$, respectivamente), uma vez que não houve variação no número de folhas por perfilho (4,5 folhas/perfilho) $(P \geq 0,10)$. As oscilações nessas características morfogênicas ao longo do experimento deveram-se ao estádio fenológico da planta, que passou de vegetativo para reprodutivo. A freqüência $(0,077$ desfolhação/perfilho.dia) e intensidade (0,296 - proporção do comprimento original removido pelo pastejo) de desfolhação de perfilhos individuais foram maiores em pastos mais baixos $(10 \mathrm{~cm})(P<0,10)$. Nos pastos mantidos mais altos $(20,30$ e 40 $\mathrm{cm})$ a intensidade de desfolhação permaneceu relativamente constante $(0,173)(P \geq$ 0,10 ), enquanto a freqüência foi decrescente com o aumento da altura do dossel forrageiro $(0,068,0,067,0,056$ para 20,30 e $40 \mathrm{~cm}$, respectivamente) $(P<0,10)$. Tendência semelhante foi obtida quando freqüência e intensidade foram calculados com base na folha do perfilho $(0,043,0,033,0,031,0,026$ e 0,760, 0,683, 0,654, 0,665, respectivamente, para 10, 20, 30 e $40 \mathrm{~cm}$ ). Houve uma relação positiva entre a taxa de lotação utilizada para manter as condições experimentais e a freqüência e a intensidade de desfolhação resultantes. Folhas senescentes sofreram desfolhação menos severa que folhas maduras e em expansão em virtude principalmente da menor freqüência com que foram visitadas $(0,009,0,028,0,024$, respectivamente), uma vez que as variações em intensidade foram pequenas. A eficiência de utilização foi maior nos pastos mantidos a $10 \mathrm{~cm}(82,3 \%)$, conseqüência da elevada freqüência e intensidade de desfolhação, o que diminuiu a longevidade das folhas naquelas condições. Pastos mantidos em alturas de dossel crescente apresentaram eficiências de utilização decrescente (76,2, 69,4 e 68,7\% para 20, 30 e $40 \mathrm{~cm}$, respectivamente). Independentemente da altura de pasto empregada, 33\% da parte superior da altura do dossel foi utilizada para pastejo, revelando potenciais restrições ao consumo de forragem de bovinos pastejando pastos baixos. 


\title{
MORPHOGENETIC CHARACTERISTICS AND DEFOLIATION PATTERNS IN MARANDU GRASS PASTURES SUBMMITED TO CONTINUOUS STOCKING REGIMES
}

\author{
Author: ALEXANDRE DE CAMPOS GONÇALVES \\ Adviser: Prof. Dr. SILA CARNEIRO DA SILVA
}

\section{SUMMARY}

The lack of information on the ecophysiology of tropical pasture species limits the adjustment of grazing management practices that allow for the best possible utilization of their forage production potential. Bearing that in mind, the present experiment, carried out at the Departamento de Zootecnia, USP/ESALQ, Piracicaba, $\mathrm{SP}$, evaluated the morphogenetic characteristics and defoliation patterns of Brachiaria brizantha (Hochst ex A. Rich) cultivar Marandu from November 2001 to February 2002. Treatments corresponded to four sward state conditions $(10,20,30$ and $40 \mathrm{~cm}$ sward surface height) generated by cattle grazing under continuous stocking with variable stocking rate and were allocated to experimental units according to a complete randomized block design with four replications. The evaluated responses were: (1) morphogenetic characteristics: leaf appearance rate (LAR), phyllochron, number of leaves per tiller and leaf life span; (2) individual tiller defoliation patterns: frequency and intensity of defoliation and grazing efficiency (utilization). Short swards $(10 \mathrm{~cm}$ ) presented higher LAR (0.12 leaf/tiller.day and 0.012 leaf/tiller.degree-day) and smaller phyllochrone (9.0 days/leaf and 84.8 degree-days/leaf) than tall swards (20, 30 and 40 
cm) $(0.11,0.10,0.10$ leaf/tiller.day and $0.011,0.011,0.010$ leaf/tiller.degree-day; 10.3 , 10.3, 10.9 days/leaf and 95.1, 95.1, 100.6 degree-days/leaf, respectively), the latter three being the same $(P \geq 0.10)$. Leaf life span followed the phyllochron results (34.4, 43.1, 45.5, 48.4 days/leaf and 332.1, 441.6, 433.5, 462.0 degree-days/leaf for the 10, 20,30 and $40 \mathrm{~cm}$ swards, respectively) since no variation was observed in number of leaves per tiller (4.5 leaves/tiller) ( $P \geq 0.10$ ). Variations in morphogenetic characteristics throughout the experiment were due to the phenological state of plants, which changed from vegetative to reproductive. Frequency ( 0.077 defoliation/tiller.day) and intensity (0.296 - proportion of the original length removed by grazing) of defoliation of individual tillers were biggest in the $10 \mathrm{~cm}$-swards $(P<0.10)$. In the 20,30 and $40 \mathrm{~cm}$-swards defoliation intensity remained relatively constant $(0.173)(P \geq 0.10)$, while defoliation frequency decreased as sward surface height increased $(0.068,0.067,0.056$ for the 20 , 30 and $40 \mathrm{~cm}$-swards, respectively) $(P<0.10)$. A similar trend was obtained when frequency and intensity of defoliation were calculated on a per leaf basis $(0.043,0.033$, $0.031,0.026$ e $0.760,0.683,0.654,0665$, respectively, for the $10,20,30$ and $40 \mathrm{~cm}$ swards). There was a positive relationship between the stocking rate used to generate experimental treatments and the resulting frequency and intensity of defoliation of individual tillers. Senescing leaves were defoliated less severely than mature and expanding leaves, particularly because of the lower frequency with which they were visited $(0.009,0.028,0.024$, respectively), since corresponding variations in defoliation intensity were small. Pasture utilization efficiency was highest in the $10 \mathrm{~cm}$-swards $(82.3 \%)$, a consequence of their high frequency and intensity of defoliation that resulted in decreased leaf life span under those circumstances. Increasing sward surface height resulted in decreasing utilization efficiency $(76.2,69.4$ and $68.7 \%$ for the 20,30 and 40 $\mathrm{cm}$-swards, respectively). Regardless of sward surface height, the top $33 \%$ of the sward height was used for grazing, indicating potential restrictions to herbage consumption of cattle grazing short pastures. 


\section{INTRODUÇÃO}

O Brasil é um país com dimensões continentais. Do total de seu território, 30\% é ocupado pelo setor agropecuário. Nesse contexto, as pastagens naturais ou cultivadas aparecem com excepcional destaque, ocupando cerca de 185 milhões de hectares, ou seja, 73\% da área destinada ao setor (FAO, 2002). Essa fonte de alimentação adquire relevância ainda maior quando é levada em consideração sua competitividade econômica, comparada aos sistemas que adotam resíduos agroindustriais, cereais e silagens como base da alimentação (HODGSON, 1990). Outro aspecto importante é a demanda crescente no mundo e, em especial, no continente europeu, por produtos oriundos de sistemas de produção que priorizam o uso de pastagens em detrimento dos sistemas confinados.

O Brasil apresenta condição privilegiada nesse sentido, uma vez que estimativas demonstram que $96,5 \%$ do plantel de bovinos é manejado exclusivamente em pastagens, sendo que dos 3,5\% restantes, praticamente todos foram criados em pastagens em algum período de suas vidas (ANUALPEC, 2002). De acordo com dados oficiais do IBGE (2002), essas pastagens abrigam um rebanho que ultrapassa 200 milhões de cabeças, das quais mais de 171 milhões só de bovinos, colocando o Brasil na condição de segundo maior rebanho bovino abrigado no mundo. Numa análise minuciosa verificase que, apesar do enorme rebanho, os resultados de produtividade das pastagens brasileiras são modestos. Elas abrigam apenas 1,1 cabeça por hectare, isso considerando bovinos, bubalinos, equinos, asininos, muares, ovinos e caprinos, valor esse equivalente a menos de 0,6 UA por hectare (IBGE, 2002).

A forma tradicional de exploração, sem cuidados em relação à produtividade $e$ eficiência de aproveitamento da forragem produzida, é ainda o maior entrave. A falta de planejamento e manejo específico para as condições tropicais do país leva inúmeros proprietários a conduzirem suas pastagens àdegradação, e promoverem a 
constante reforma do pasto ou substituição da espécie forrageira, buscando a "planta ideal", que produza um alimento abundante e com elevado valor nutricional sem exigir o uso de insumos e/ou práticas de manejo mais apuradas (DA SILVA \& PEDREIRA, 1997). Na incapacidade de atingir êxito nessa empreita, os resultados zootécnicos obtidos pelos pecuaristas são modestos. O desfrute brasileiro é $23,4 \%$ menor que o da vizinha Argentina, 47,5\% menor que o da Austrália, que também explora o sistema de produção em pastagens, e 64,1\% menor que o dos Estados Unidos (FAO, 2002).

Transformar esse quadro de baixo desempenho exige da comunidade científica esforço no sentido de elucidar as questões acerca do manejo das pastagens tropicais. Cabe a ela definir estratégias que permitam maior eficiência no aproveitamento dessas pastagens pelo ajuste entre seu elevado potencial de produção de massa com o ponto de pastejo, onde o valor nutritivo da mesma ainda seja elevado, favorecendo a obtenção de alto desempenho animal. Isso tudo passa, irrevogavelmente, pelo entendimento de seu comportamento morfológico e fisiológico quando submetida ao pastejo direto por animais. No entanto, poucos estudos com plantas forrageiras (15\%) vêm sendo historicamente desenvolvidos com a inclusão da variável animal como parte da proposta experimental, sendo a maior porção realizada em casas de vegetação ou sem quantificar os reais efeitos da ação animal sobre a ecofisiologia da planta forrageira (FARIA et al., 1996).

LEMAIRE \& CHAPMAN (1996) afirmaram que quanto mais intensa e freqüente for a desfolhação, maior a oportunidade de colheita e eficiência de utilização da forragem produzida, permitindo que melhores resultados zootécnicos e econômicos sejam atingidos pela pecuária. Apesar da relevância desses conceitos, é comum verificar técnicos e pesquisadores confundindo termos como freqüência e intensidade de desfolhação, ou até mesmo desconhecendo-os. Esse fato decorre do número limitado de trabalhos cujo detalhamento permita elucidar as questões nesse sentido.

Com base no exposto, é importante que sejam desvendados os "mistérios" da ecofisiologia das plantas forrageiras tropicais quando submetidas a desfolhação por animais, para que seja possível estabelecer estratégias de manejo baseadas em conhecimento científico e não em empirismo. Este trabalho teve como objetivo contribuir para a elucidação de parte das questões acerca da dinâmica de desfolhação da Brachiaria brizantha (Hochst ex A. Rich) cultivar Marandu, uma das gramíneas tropicais de maior representatividade no Brasil. Enfoque maior foi dado àfreqüência $\mathrm{e}$ 
intensidade de desfolhação que, combinados a características morfogênicas da planta em estudo, permitiram descrever aspectos da interface planta:animal essenciais para o planejamento de práticas de manejo do pastejo. 


\section{REVISÃO DE LITERATURA}

\section{1 - ASPECTOS DE COMUNIDADES DE PLANTAS FORRAGEIRAS}

\subsection{1 - Unidades básicas das plantas - perfilhos}

Uma planta forrageira é composta por um conjunto de perfilhos ou afilhos que, de acordo com HODGSON (1990), são definidos como as unidades modulares de crescimento de gramíneas forrageiras formadas por: (a) folhas completamente expandidas e fotossinteticamente ativas; (b) folhas em expansão que ainda não atingiram a sua capacidade fotossintética total; (c) folhas que ainda não emergiram e dependem dos fotoassimilados produzidos por folhas mais velhas para crescer; (d) folhas senescentes; (e) meristema apical; (f) gemas axilares; e, dependendo do tipo de perfilho, (g) sistema radicular.

Quando se considera a comunidade de plantas que compõem uma pastagem já estabelecida e submetida a corte ou pastejo, podem ser encontrados diferentes tipos de perfilhos, em diversas fases de desenvolvimento, caracterizando uma hierarquia de perfilhos, que foram classificados por LANGER (1963) como: (a) perfilhos principais, aqueles que se originaram a partir da emergência das plântulas; (b) perfilhos primários, aqueles que se originaram a partir dos perfilhos principais; (c) perfilhos secundários, aqueles originados a partir dos primários; e assim sucessivamente. Com exceção da gema apical, os perfilhos aparecem na ordem natural da sucessão foliar determinada geneticamente, mas são as condições de ambiente, juntamente com a expressão genética da planta, que decidem qual gema será a primeira a iniciar seu desenvolvimento (GOMIDE, 1997). 
JEWISS (1972) apresentou ainda outra denominação, com base na localização da gema de crescimento (local de origem). Segundo essa classificação, perfilhos que emergem de gemas localizadas na base da coroa das plantas são chamados de perfilhos basais, e os oriundos de gemas laterais dos perfilhos principais são os perfilhos aéreos. $O$ mesmo autor mencionou que, conforme o estádio de desenvolvimento, esses perfilhos podem ser caracterizados como vegetativos ou reprodutivos, sendo esses últimos caracterizados pela emissão da inflorescência ao final de seu ciclo de vida.

\subsection{2 - Comunidade de plantas forrageiras - populações de perfilhos}

Durante as primeiras etapas de crescimento, a taxa de produção de folhas e de perfilhos é linear, mas como esse é um processo contínuo para todas as plantas, o aumento no número total de perfilhos do relvado é exponencial enquanto não houver limitação no meio (LANGER, 1963). Uma vez atingido o equilíbrio com a disponibilidade de luz na área, inicia-se um processo de morte de perfilhos dependente da densidade populacional, resultando num balanço dinâmico entre número e peso (tamanho) de perfilhos (MATTHEW et al., 1995; SBRISSIA et al., 2001).

PARSONS (1988) mencionou que a pesquisa em manejo do pastejo tem por objetivo encontrar o ponto ótimo entre a necessidade da planta forrageira de conservar sua área foliar e a prerrogativa fundamental de remover esse tecido através de corte ou pastejo para a manutenção da produção animal. Dentre os fatores que afetam o fluxo de tecidos, o perfilhamento é o que exerce a maior influência sobre as variáveis de acúmulo de forragem (DA SILVA \& PEDREIRA, 1997), sendo sua dinâmica determinada por diversos fatores: genótipo da planta, balanço hormonal, estádio de desenvolvimento (vegetativo $\mathrm{x}$ reprodutivo), fotoperíodo, temperatura, intensidade luminosa, disponibilidade de nutrientes e água (LANGER, 1963).

A premissa básica da produção animal em pastagens é a remoção e o consumo da área foliar das plantas forrageiras para alimentação animal, que acaba por promover alterações e ajustes no crescimento e na população de perfilhos (GRANT \& KING, 1983). Alterações na área foliar, medidas pelo índice de área foliar (IAF), influenciam diretamente a capacidade de interceptação luminosa da planta e do dossel, promovendo mudanças tanto em suas características morfogênicas, pela alteração na 
taxa de alongamento de folhas, quanto em suas características estruturais, quer diretamente sobre a densidade populacional de perfilhos, quer indiretamente pelos efeitos derivados da alteração na taxa de alongamento de folhas. Essas mudanças visam assegurar a rebrotação e a perenidade da planta forrageira, e integram um conjunto de características adaptativas chamado plasticidade fenotípica (LEMAIRE \& CHAPMAN, 1996). Como o tamanho e o número de folhas por perfilho têm plasticidade limitada, o ajuste no IAF do pasto é feito com maior rapidez através de variações na população de perfilhos (MATTHEW et al., 1999), sendo que quanto maior o número de perfilhos maior a competição entre eles por luz e, com isso, menor seu desenvolvimento e tamanho final. A contrapartida também é válida, ou seja, quanto menor o número de perfilhos, maior seu desenvolvimento (BRISKE, 1996). De acordo com BIRCHAM \& HODGSON (1983), é esse mecanismo de controle "homeostático" de comunidades de plantas em pastagens o responsável pelas mudanças na dinâmica populacional de perfilhos, promovendo o ajuste entre o peso e número dos mesmos de maneira a minimizar o efeito da desfolhação sobre o IAF do pasto. HODGSON (1990) descreveu com propriedade o ciclo de vida de uma comunidade de perfilhos, apontando que os perfilhos surgem, desenvolvem-se, aumentam de tamanho e acabam promovendo um "auto-desbate" em perfilhos mais fracos, localizados mais próximos ao solo, onde a luminosidade é baixa. Contudo, quanto maior o tamanho dos perfilhos, menor o número de perfilhos que podem ser mantidos na área (MATTHEW et al., 1995; SBRISSIA et al., 2001).

\section{2 - MORFOGÊNESE DE PLANTAS FORRAGEIRAS E ESTRUTURA DO RELVADO}

A estrutura de um dossel forrageiro é definida por um conjunto de características genéticas da planta, denominadas características morfogênicas, que são condicionadas por fatores de ambiente como luz, temperatura, umidade e outros (LEMAIRE \& CHAPMAN, 1996). A dinâmica da geração ("genesis") e da expansão da forma da planta ("morphos") no espaço definem a morfogênese de plantas (CHAPMAN \& LEMAIRE, 1993), a qual pode ser descrita a partir de três características básicas: (a) aparecimento de folhas; (b) alongamento de folhas e; (c) tempo de vida de cada folha. Apesar dessas características serem determinadas geneticamente, sofrem grande 
influência de fatores de ambiente, principalmente luz, temperatura e umidade (LEMAIRE \& CHAPMAN, 1996). Diferentes combinações dessas características morfogênicas definem a estrutura de uma planta forrageira, expressa através de três características estruturais básicas: tamanho da folha, medida quando totalmente expandida (após aparecimento da lígula); densidade populacional de perfilhos, medida pela contagem do número de perfilhos por unidade de área; e número de folhas por perfilho (LEMAIRE \& CHAPMAN, 1996). O tamanho das folhas de um perfilho é determinado pela relação entre a taxa de alongamento de folhas e a taxa de aparecimento das mesmas, uma vez que ao ser emitida a folha seguinte, a primeira tem seu crescimento interrompido, apenas permanecendo ativa por determinado período de tempo. A densidade populacional de perfilhos é influenciada basicamente pela taxa de aparecimento de folhas podendo, no entanto, ser alterada em condições de desfolhação pela variação na quantidade e qualidade da luz incidente que atinge o dossel de folhas remanescentes. O número de folhas por perfilho é o produto entre 0 tempo de vida de cada folha e a taxa de aparecimento das mesmas. O produto dessas três características estruturais determina diretamente o índice de área foliar (IAF) de uma pastagem. Em plantas tropicais e subtropicais, o alongamento de hastes assume importância relativa grande como característica morfogênica e determina variáveis estruturais do dossel como a relação folha:haste, por exemplo (SBRISSIA \& DA SILVA, 2001).

Dependendo da forma, estrutura e arranjo do aparato fotossintético, ou seja, do dossel de folhas e hastes de uma comunidade de plantas forrageiras, assegura-se uma maior ou menor qualidade da luz interceptada que, por sua vez, afeta tanto a taxa de alongamento de folhas e hastes, pelo maior aporte de fotoassimilados, como também a densidade populacional de perfilhos (HODGSON, 1990). Em condições ótimas de desenvolvimento, o fator de maior competição na comunidade de perfilhos é a luz, de forma que baixa disponibilidade dá início aos processos de morte e senescência de perfilhos. Esse fato foi comprovado por DEINUM et al. (1996) que, em experimento conduzido em casa de vegetação, verificaram que o perfilhamento em Brachiaria brizantha foi fortemente estimulado com o aumento da intensidade de luz. A elevação do IAF propicia uma maior interceptação de luz pelo dossel, o que garante maior atividade fotossintética e, portanto, maior produção de massa seca (PARSONS et al., 1983b). Entretanto, em situações de alto IAF, passa a existir restrição de luz, 
aumentando a competição na comunidade de plantas por esse fator de crescimento. Nessas condições, as folhas mais velhas, situadas em pontos mais baixos do dossel, sofrem maior sombreamento e, por conseguinte, são as primeiras a senescer.

É a contínua emissão de folhas e perfilhos que promove a restauração da área foliar após a desfolhação por corte ou pastejo, assegurando a produtividade e a perenidade da pastagem (GOMIDE \& GOMIDE, 1999). Durante a ontogenia dos perfilhos, as folhas aparecem a intervalos regulares caracterizados pela formação dos chamados fitômeros (WILHELM \& McMASTER, 1995). Nesse cenário, o inverso do tempo para o aparecimento de duas folhas sucessivas estima a taxa de aparecimento de folhas, quantificada em número de folhas por dia ou número de folhas por graus-dia. De acordo com CHAPMAN \& LEMAIRE (1993), a taxa de aparecimento de folhas é a característica morfogênica que merece maior destaque, uma vez que influencia diretamente as três características estruturais do relvado: tamanho da folha, densidade populacional de perfilhos e número de folhas por perfilho. ZARROUGH et al. (1984) revelaram uma correlação negativa entre a taxa de aparecimento e o alongamento das folhas, indicando que quanto maior a taxa de aparecimento, menor o tempo para o alongamento das folhas.

Diversos fatores afetam a taxa de aparecimento de folhas, dentre eles alguns aspectos intrínsecos da planta forrageira como espécie e/ou cultivar (GRANT et al., 1988; PINTO et al., 1994) e características morfológicas como nível de inserção de folhas (SKINNER \& NELSON, 1995). Já VAN ESBROECK et al. (1997) deixaram claro que é a temperatura o fator que exerce maior influência, daí a opção por expressar a taxa de aparecimento de folhas em graus-dia. Além da temperatura, outros fatores de ambiente interferem, como a água, nutrientes minerais (LAWLOR, 1995) e a luz (SILSBURY, 1970).

GRANT et al. (1988) ponderaram que o padrão de desfolhação também exerce efeito sobre o aparecimento de folhas, principalmente quando relacionado ̀̀s alterações na altura do relvado e à oferta de forragem. Esses resultados foram corroborados por PARSONS et al. (1991a), que demonstraram em seu trabalho que folhas de azevém perene (Lolium perenne L.) aparecem mais lentamente em relvados mantidos mais altos, demorando mais para completar sua expansão. Esses autores relataram, ainda, o efeito da estação do ano sobre o aparecimento de folhas, situação em que as menores taxas ocorreram durante a primavera e o outono. O consórcio 
entre gramíneas e leguminosas temperadas, azevém perene e trevo branco (Trifolium repens L.), promoveu incremento na taxa de aparecimento de folhas da gramínea quando comparada àcondição de monocultura (PARSONS et al., 1991a).

O inverso da taxa de aparecimento de folhas, correspondendo ao intervalo de tempo decorrido para que duas folhas sucessivas atinjam o mesmo estádio de desenvolvimento fisiológico (GOMIDE, 1997), é normalmente conhecido como filocrono e expresso como dias por folha ou graus-dia por folha. $O$ filocrono é influenciado pelos mesmos fatores que interferem na taxa de aparecimento de folhas. Além desses fatores, VAN ESBROECK et al. (1997) citaram que em Panicum virgatum (L.) o filocrono não é afetado pelo déficit hídrico nem, tampouco, pela deficiência de nitrogênio.

Folhas apresentam um tempo de vida limitado, o qual é determinado por características genéticas e influenciado por fatores de ambiente e de manejo (HODGSON et al., 1981). Uma vez iniciado o processo de senescência ou morte da folha, ela passa a perder massa progressivamente. Qualquer prática de manejo que resulte em redução da disponibilidade de recursos ambientais, principalmente luz, pode ocasionar incremento no processo de senescência das folhas reduzindo, assim, sua longevidade (HODGSON et al., 1981).

Existe um sincronismo entre o aparecimento e a morte de folhas percebido com mais facilidade em pastos mantidos em condições de equilíbrio ("steady state"), onde o número de folhas mantidas vivas em cada perfilho permanece constante após algum tempo (LEMAIRE \& CHAPMAN, 1996). Esse número é função da taxa de aparecimento e do tempo de vida de cada folha, ambas características morfogênicas. Após atingida a condição de equilíbrio em um dossel forrageiro, o número de folhas vivas por perfilho fica relativamente constante para plantas de um mesmo cultivar ou espécie (GOMIDE, 1997; VAN ESBROECK et al., 1997). Por ser resultado da combinação de características morfogênicas, sofre influência direta e indireta de fatores relacionados ao ambiente e æ̀ práticas de manejo utilizadas (GOMIDE, 1997). Essa relativa constância incute no número médio de folhas por perfilho um destaque especial do ponto de vista do manejo do pastejo, podendo essa característica estrutural servir como critério objetivo e prático para definição da duração do período de descanso de métodos de desfolhação intermitente (FULKERSON \& SLACK, 1995), de forma a prevenir perdas excessivas por senescência de folhas. 


\section{3 - O PROCESSO DE ACÚMULO DE FORRAGEM EM PASTAGENS}

De acordo com DA SILVA \& PEDREIRA (1997), o acúmulo de forragem em pastagens é o resultado de interações complexas de onde advém a combinação dos atributos genéticos de uma dada planta forrageira e os efeitos do ambiente sobre seus processos fisiológicos e características morfofisiológicas para a determinação da produtividade. HODGSON et al. (1981) definiram o acúmulo de forragem da pastagem como sendo um processo dinâmico e resultado do balanço entre crescimento e senescência/decomposição de tecidos. No caso específico de plantas sob condições de pastejo, considera-se no balanço o material consumido pelos animais, tornando o acúmulo de forragem o balanço líquido entre o crescimento, consumo e as perdas por senescência (BIRCHAM \& HODGSON, 1983). Em casos onde a pastagem é mantida em condição constante ("steady state"), como em alguns casos de lotação contínua, o acúmulo de forragem pode chegar a zero, uma vez que todo material produzido é removido através do pastejo pelos animais (BIRCHAM \& HODGSON, 1983).

O desenvolvimento vegetativo de uma gramínea é caracterizado pela produção de tecidos que originam folhas e perfilhos, o alongamento do colmo e o aparecimento do sistema radicular (SILSBURY, 1970). Essa produção de massa seca é originada da energia luminosa interceptada pelo dossel forrageiro e da capacidade desta em transformar essa energia quando somada a outros nutrientes nos tecidos vegetais. COOPER \& WILSON (1970) relataram que a taxa de transformação da energia luminosa em tecidos é dependente da eficiência fotossintética de folhas individuais, de características do dossel para interceptar a luz incidente, e da distribuição dos tecidos produzidos ao longo do perfil do dossel forrageiro.

Folhas são formadas a partir do desenvolvimento de primórdios foliares que surgem na forma de pequenas protuberâncias, alternadamente de cada lado do domo apical (LANGER, 1972), em posições regulares, definidas e características para cada espécie de planta forrageira (PINTO et al., 1994). Cada primórdio foliar dá origem a um fitômero constituído de lâmina e bainha foliares, entrenó, nó e gema (WILHELM \& McMASTER, 1995). Segundo HODGSON (1990), a produção de folhas num perfilho é um processo contínuo, onde cada uma das folhas apresenta características próprias em seu ciclo de vida, como um período de ativa expansão (crescimento), uma fase de máximo desempenho fotossintético (maturidade) seguida de uma fase de senescência 
e, por fim, morte, caso essa folha não venha a ser colhida. As primeiras folhas, emergindo de um pseudo-colmo curto, têm uma rápida emergência e atingem pequenos comprimentos. As folhas seguintes, por necessitarem percorrer um percurso mais longo para emergir, alcançam comprimentos maiores (SKINNER \& NELSON, 1995). Quando a planta forrageira entra em estádio reprodutivo e dá início àelongação da haste, cessa o aparecimento de novas folhas e, com isso, a produção de massa seca de folhas desse perfilho. Enquanto a haste reprodutiva não for cortada ou morrer, novas folhas não voltam a aparecer nesse perfilho (HODGSON, 1990).

BROUGHAM (1956) relacionou a produção de massa seca àporcentagem de luz interceptada pelo dossel forrageiro e mencionou que esta apresentou valores crescentes até que existisse área foliar suficiente para interceptar $95 \%$ da luz incidente, patamar onde ocorreu a máxima taxa de acúmulo líquido de forragem nos pastos de azevém perene estudados. Acima de $95 \%$ de interceptação de toda luz incidente passa a existir uma acirrada competição por esse fator de produção, levando ao decréscimo na taxa de crescimento e acentuando-se o processo de senescência.

Em trabalho posterior, o mesmo autor (BROUGHAM, 1957) descreveu o desenvolvimento das plantas forrageiras por meio de curvas de crescimento divididas em 3 fases: (1- FASE) taxa de crescimento aumentando de forma exponencial, influenciada, principalmente, pelas reservas orgânicas da planta, área foliar remanescente e umidade do solo; ( $2^{\mathbf{a}}$ FASE) taxa de crescimento atingindo um valor máximo, iniciando a competição intra e inter espécies por fatores de produção, em especial a luz, tendo início também o processo de senescência; (3 FASE) taxa de crescimento sofrendo suave declínio no princípio e, posteriormente, redução mais acentuada, podendo, em situações especiais, chegar a zero ou até mesmo tornar-se negativa; nessa fase o aumento da limitação de fatores de produção promove uma maior disputa por eles, acelerando a senescência de tecidos, principal agente de perdas nessa fase.

Segundo PARSONS et al. (1983a), a fisiologia de um pasto submetido a condições de rebrotação ou crescimento e de outro mantido com área foliar relativamente constante é bastante diferente. No caso da rebrotação, onde o relvado parte de uma baixa área foliar inicial crescendo até adquirir alta área foliar, a fotossíntese bruta cresce conforme o aumento em área foliar, sendo acompanhada da taxa de produção de novos tecidos. Nessa condição, é percebido um atraso entre o 
processo de produção de tecidos e a senescência ou morte dos mesmos, originando uma fase em que a taxa de acúmulo de forragem é máxima. Passada essa fase, ou nos relvados mantidos sob área foliar relativamente constante e suficiente para interceptar $95 \%$ de toda luz incidente, deixa de existir vantagem entre a taxa de produção de tecidos e o processo de senescência foliar, uma vez que embora exista uma alta taxa fotossintética e, com isso, de produção bruta de tecidos, ocorre também uma alta taxa de senescência e morte desses tecidos. Nessas condições, caso o pasto continue crescendo e intercepte praticamente toda luz incidente, o processo de senescência assume tal proporção que se iguala a produção de tecidos, resultando em acúmulo líquido de forragem igual a zero (PARSONS et al., 1983b).

A senescência é um processo natural para o qual existe uma programação genética da planta forrageira (SALISBURY \& ROSS, 1992). Como conseqüência da limitada longevidade das folhas, após um determinado tempo de vida fenômenos fisiológicos que determinam o processo de senescência são desencadeados (HODGSON, 1990). Nesse instante, as folhas perdem clorofila, RNA e proteínas, inclusive enzimas (SALISBURY \& ROSS, 1992), provocando a mudança da coloração do tecido foliar para tons amarelados e, posteriormente, amarronzados e enegrecidos (WILMAN \& MARES MARTIN, 1977). Nos estádios iniciais, muitos dos compostos solúveis podem ser remobilizados para uso em outras partes da planta, mas, no entanto, a maior parte deles acaba sendo utilizada para respiração da folha e de bactérias e fungos que vivem sobre seu limbo. O mesmo efeito visualizado nas folhas pode acometer os perfilhos como um todo, sendo esse normalmente desencadeado quando o meristema apical é removido por corte ou pastejo (HODGSON, 1990).

PARSONS et al. (1988) ponderaram que maximizar a fotossíntese e a taxa de produção total de tecidos acaba levando a uma elevada taxa de senescência de tecidos caso não haja tempo hábil ou número de animais suficiente para colheita. Porém, é necessário conviver com patamares aceitáveis de senescência em função da necessidade de assegurar a produção animal através de ofertas generosas de forragem, muitas vezes bastante acima da capacidade de ingestão do animal (NABINGER, 1997).

Características relacionadas ao ambiente e ìs práticas adotadas de manejo da desfolhação apresentam interferência sobre a dinâmica do acúmulo de forragem. $O$ fator de ambiente mais influente é a luz, pois potencializa a produção ce tecidos 
quando abundante e induz a senescência dos mesmos quando em quantidade insuficiente (BROUGHAM, 1956). Limitações de água e outros nutrientes também interferem em ambos os processos.

\section{4 - RESPOSTAS A REGIMES DE DESFOLHAÇÃO}

\subsection{1 - Produção de forragem}

A capacidade adaptativa de uma planta forrageira a condições de desfolhação, chamada plasticidade fenotípica, desconhecida para grande maioria das espécies tropicais, é quem determina seu potencial de exploração (LEMAIRE \& CHAPMAN, 1996). Modelos de produção baseados na utilização de pastagens apresentam, de maneira geral, duas formas básicas de exploração. A lotação contínua, onde animais são mantidos por períodos longos de tempo numa dada área, variando-se ou não a densidade de lotação utilizada, e a lotação intermitente, que adota períodos de pastejo sucedidos por períodos de descanso onde nenhum animal é mantido no local após realizado o pastejo.

A lotação intermitente apresenta uma diferença fundamental em relação à lotação contínua, que é a existência de períodos bem definidos onde a área foliar cresce livremente na ausência de desfolhação. Durante esses períodos de rebrotação, são observadas taxas altas de acúmulo de forragem devido à interceptação luminosa crescente e ao aproveitamento do diferencial de tempo entre o início dos processos de crescimento e senescência de folhas, favorecendo o primeiro processo e atingindo picos de produção potencial maiores (DA SILVA \& PEDREIRA, 1997). Na lotação contínua, embora o dossel permaneça acessível à desfolhação por maior período de tempo, os animais consomem quantidades relativamente pequenas de tecidos senescentes. Portanto, quanto mais tecido avança rumo à senescência, maiores as perdas do sistema (HODGSON et al., 1981). Nessa situação, a possibilidade de uma folha ser pastejada antes de iniciar sua senescência está intimamente relacionada com a densidade de lotação empregada, intensidade de desfolhação e proporção de tecido vivo removido pelo animal em pastejo (LEMAIRE \& AGNUSDAI, 1999). 
Segundo HUGHES \& JACKSON (1974), em situações de lotação contínua onde o relvado é mantido com baixa área foliar, as plantas, na intenção de reduzir a severidade de desfolhação a que estão submetidas, promovem alterações em sua densidade populacional gerando um número maior de perfilhos pequenos com características de crescimento mais prostrado. Essa maior população de perfilhos, produzindo um grande número de folhas pequenas, assegura ao dossel a interceptação luminosa e maiores taxas fotossintéticas para manutenção da produtividade. Sob essas condições, uma grande proporção do material produzido é colhido através do pastejo, reduzindo significativamente as perdas por senescência e elevando a eficiência de colheita do material produzido (utilização). No caso de lotação contínua associada a altos índices de área foliar, é inevitável que apenas uma porção reduzida do material produzido seja colhida, ficando uma grande quantidade de tecido no pasto à disposição para atuar na fotossíntese. No entanto, nessas circunstâncias, também ocorre a elevação das perdas por senescência, sendo a eficiência de colheita da forragem relativamente baixa.

Em regimes de lotação intermitente, o tecido foliar remanescente após a desfolhação corresponde a folhas que se encontravam em condições de sombreamento, de menor eficiência fotossintética, razão pela qual a rebrotação inicial é lenta até que surja um número suficiente de folhas novas com alta capacidade fotossintética capaz de promover aumentos crescentes na taxa de produção (NABINGER, 1997; PARSONS et al., 1988). Quanto mais severa for a desfolhação, maior a duração da fase de desenvolvimento de folhas novas, ficando a comunidade de plantas em condições de balanço de carbono negativo por maior período de tempo (respiração > fotossíntese).

Aparentemente, gramíneas tropicais de hábito de crescimento ereto, por apresentarem elongação de haste marcante, estariam melhor adaptadas a regimes intermitentes. Entretanto, comparações como essa ainda são de pouca valia considerando a falta de estudos básicos que possibilitem um melhor entendimento dos princípios fisiológicos que governam o crescimento e utilização de pastagens submetidas a esses dois métodos de desfolhação.

PARSONS et al. (1988) indicaram uma produtividade de forragem teórica superior em até $20 \%$ para métodos de desfolhação baseados em lotação intermitente quando utilizando azevém perene. Entretanto, alertaram para a dificuldade de 
reconhecer essa diferença na prática, uma vez que uma maior produção de forragem não implica, necessariamente, em colheita eficiente do material produzido (GRANT et al., 1988; PARSONS \& CHAPMAN, 1988). Apesar da similaridade em termos de potencial de produção de forragem a partir dos dois métodos de pastejo descritos, HODGSON (1984) apontou que decisões de manejo baseadas nas condições (estrutura) do relvado apresentam um melhor efeito sobre a manipulação do desempenho tanto de animais como de plantas, e que essas decisões seriam aplicadas com maior facilidade em situações de lotação intermitente relativamente àquelas de lotação contínua.

\subsection{2 - Ingestão de forragem pelos animais em pastejo}

POPPI et al. (1987) relataram a existência de diversos fatores interferindo no consumo de forragem de animais em pastejo, classificando-os em fatores nutricionais e não-nutricionais. Os autores denominaram como fatores nutricionais aqueles relacionados com a digestibilidade, taxa de passagem e concentração de metabólitos da digestão dos alimentos. Já como fatores não nutricionais relacionaram a habilidade do animal em efetuar o pastejo, a qual é influenciada pela estrutura do relvado no que diz respeito à facilidade de acesso ao alimento e à proporção de folhas verdes relativamente a material senescente/morto e hastes, e pelo próprio comportamento ingestivo do animal, onde estão inclusos a seleção da dieta, o tempo demandado com a atividade de pastejo, o tamanho dos bocados e a taxa com que eles são realizados. Em situações especiais, onde a disponibilidade de forragem e o acesso a ela não são limitados, os fatores nutricionais parecem ter maior importância no controle da ingestão. Entretanto, na maioria das vezes, essas situações especiais não ocorrem e são os fatores não nutricionais, através de restrições físicas ou mecânicas, que acabam por exercer maior influência sobre o consumo de forragem dos animais em pastejo (POPPI et al., 1987).

COSGROVE (1997) e POPPI et al. (1987) apontaram que a ingestão de forragem é função da quantidade de tempo despendido com o pastejo e da taxa com que a forragem é consumida. Essa taxa de consumo é função do tamanho do bocado e da taxa com que esses bocados são realizados (HODGSON, 1981). Segundo COSGROVE (1997), a quantidade de alimento apreendida em cada bocado depende 
diretamente do volume do bocado e da densidade volumétrica da forragem na porção do dossel forrageiro (estrato) sendo pastejada.

A taxa de consumo sofre influência da massa de forragem e da altura do relvado. Em condições de relvados com altura reduzida ou pouca densidade de forragem, o animal busca compensar esse efeito através de um aumento no tempo gasto com o pastejo. No entanto, o aumento em tempo de pastejo ocorre até que o esforço despendido na atividade deixe de compensar através do ganho de energia proveniente do alimento. Nesse momento, o tamanho do bocado, taxa de bocado e tempo de pastejo diminuem drasticamente (HODGSON, 1981; POPPI et al., 1987). Quando o tempo destinado ao pastejo excede um limite de cerca de 13 horas diárias, passa a comprometer as atividades de ruminação e repouso do animal, afetando negativamente o consumo (POPPI et al., 1987). A escolha dos horários de pastejo está diretamente ligada às condições de ambiente e, em especial, àtemperatura, podendo inclusive limitar o tempo de pastejo (COSGROVE, 1997).

A taxa de bocados indica o número de bocados que um animal executa por unidade de tempo, em geral expressa em número de bocados por minuto. Cada bocado compreende o tempo gasto pelo animal para apreender a forragem através de seu aparato bucal, além dos tempos de mastigação e deglutição (HODGSON, 1984). A taxa de bocados aumenta àmedida que a altura do relvado decresce, conseqüência do menor tamanho de bocado. Outro fator que pode influenciar negativamente na taxa de bocados é a seletividade do animal durante o pastejo, quer pelo maior tempo gasto na procura pelo alimento, quer pela maior manipulação do alimento dentro da boca (COSGROVE, 1997).

O tamanho do bocado é uma combinação complexa entre a área e a profundidade do bocado, relacionadas às características do relvado (COSGROVE, 1997). A profundidade do bocado está relacionada positivamente com a altura do relvado e negativamente com a densidade do mesmo, sendo essas as características mais importantes para gramíneas temperadas (LACA et al., 1992). No caso de gramíneas tropicais, características estruturais do relvado como a presença de hastes (BARTHRAM \& GRANT, 1984), material morto e inflorescências, e a proporção de folhas verdes se revelaram igualmente importantes na limitação da profundidade de bocado (STOBBS 1975). POPPI et al. (1987) ratificaram esses conceitos ao afirmar que os bocados aumentam de tamanho com a elevação da altura do relvado até o 
limite onde essa altura sofre influência maior da estrutura (hastes), prejudicando o tamanho do bocado pela necessidade do animal selecionar melhor a dieta.

A oferta de forragem é entendida como a quantidade de forragem disponibilizada por animal num determinado tempo (HODGSON, 1984). Variações nas condições do relvado e na oferta de forragem influenciam o desempenho animal pelos efeitos que provocam na quantidade e valor nutritivo da forragem consumida. Os melhores resultados de desempenho animal têm sido relacionados a valores de oferta de forragem 3 a 4 vezes superiores æ̀s exigências diárias de massa seca dos animais (COMBELLAS \& HODGSON, 1979). Entretanto, a ocorrência de prejuízos ao consumo só passa a adquirir efeito drástico quando a oferta é inferior a 2 vezes a necessidade diária de ingestão do animal (HODGSON, 1984).

A espécie animal em pastejo também influencia o consumo de forragem, sendo os bovinos capazes de fazer uso de pastagens mais altas melhor que os ovinos e caprinos, ocorrendo o inverso em relvados baixos. Através dos movimentos de cabeça e da língua, os bovinos conseguem apreender grande quantidade de material num relvado alto, enquanto em relvados baixos os movimentos labiais dos ovinos e caprinos permitem a melhor apreensão e colheita das folhas (POPPI et al., 1987). Dentro de uma mesma espécie animal, são verificadas variações em consumo conforme a categoria a que o indivíduo pertence. Animais em final de gestação ou em lactação consomem maior volume de forragem que animais secos, vazios ou em início de gestação (HODGSON, 1990). Animais de maior porte apresentam bocados mais profundos que animais de menor porte, encerrando um maior volume de forragem por bocado (ILLIUS et al., 1995).

Segundo MAXWELL \& TREACHER (1987), a altura do relvado afeta o consumo de forragem e o desempenho animal. O consumo aumenta com a elevação da altura do pasto até um patamar onde permanece constante. Esse patamar varia conforme a espécie e a categoria animal (HODGSON, 1990). As alturas de manejo devem estar ajustadas à estação do ano e ao estádio fenológico da planta forrageira. Mantendo pastos em alturas menores em determinados momentos, é possível diminuir a emissão de hastes reprodutivas que reduzem, temporariamente, a digestibilidade da forragem e a produtividade dos pastos, uma vez que quando o perfilho entra em reprodução cessa a emissão de novas folhas (MAXWELL \& TREACHER, 1987). 


\subsection{3 - Padrões de desfolhação de perfilhos individuais}

O padrão de desfolhação de um relvado corresponde a uma somatória dos padrões de desfolhação dos perfilhos individuais que o compõem (HU, 1993). Estratégias de manejo do pastejo que resultam em variações de altura do dossel, densidade de lotação e outros exercem influência nos padrões de desfolhação dos perfilhos, em especial sobre a intensidade e freqüência, provocando, conforme o manejo escolhido, um efeito positivo ou negativo sobre a eficiência de colheita e produção de forragem (HODGSON et al., 1981).

\subsubsection{1 - Intensidade de desfolhação}

De acordo com BOOTSMA (1990) e HODGSON (1990), a intensidade de desfolhação indica a proporção do tecido vegetal removido pelo pastejo em relação ao disponibilizado para kastejo. WADE (1991) definiu essa intensidade como a redução no comprimento original de um perfilho estendido após ser submetido ao pastejo, ou seja, a diferença entre o tamanho original do perfilho e seu tamanho após realizado o pastejo (profundidade de desfolhação), expressa como proporção do tamanho original. Essa definição é apropriada quando a participação de hastes na estrutura do dossel é relativamente pequena, como é o caso de gramíneas temperadas onde a restrição física provocada pela presença das hastes limitando a profundidade de pastejo é pouco significativa. No caso de gramíneas tropicais, onde há uma grande participação de hastes, a definição apresentada por LEMAIRE \& CHAPMAN (1996) parece ser mais adequada. Segundo esses autores, a intensidade de desfolhação é definida como sendo a proporção do comprimento inicial de uma folha que é removida durante um período de pastejo. Ao medir apenas as folhas, admite-se a importância da restrição física representada pelo posicionamento das hastes sobre a profundidade de desfolhação e caracteriza-se a intensidade de pastejo como sendo relativa àremoção de área foliar apenas, de forma análoga ao que ocorre em plantas temperadas em que o meristema apical permanece sempre muito próximo do nível do solo durante sua fase de desenvolvimento vegetativo.

Ao revisar a literatura, nota-se que a altura pós pastejo e a intensidade de desfolhação são freqüentemente utilizados como sinônimo. Entretanto, é preciso 
enfatizar que essas características possuem significados distintos. Por um lado tem-se a intensidade de desfolhação que, como foi visto, é representada pela proporção de material removido durante o processo de desfolhação. Do outro, a altura pós pastejo que, sozinha, indica apenas a quantidade de material remanescente deixado após um período de pastejo.

LEMAIRE \& CHAPMAN (1996) relataram que em regimes de lotação contínua surge uma situação onde o rebaixamento do relvado acontece de forma lenta e, concomitantemente, ocorre a reconstituição da camada pastejada através do crescimento das plantas forrageiras. Na lotação intermitente, o rebaixamento e a rebrotação do relvado aparecem de forma mais pontual e, por essa razão, são processos mais facilmente delimitados e distintos. WADE et al. (1989), em experimento com vacas leiteiras submetidas a regimes de lotação contínua e intermitente sob diferentes alturas de relvado de azevém perene, demonstraram que a proporção da altura inicial do relvado removida a cada pastejo permaneceu relativamente constante e ao redor de 35\%, independentemente da altura inicial do pasto e do método de pastejo adotado. Valores semelhantes foram encontrados por MAZZANTI \& LEMAIRE (1994) em estudos com festuca (Festuca arundinacea L.), onde avalioutse a proporção do comprimento do perfilho removida após o pastejo. BURLINSON et al. (1991) e LACA et al. (1992) encontraram valores diferentes de intensidade de desfolhação, da ordem de $50 \%$, tanto para ovinos como para bovinos mantidos em pastagens artificiais de gramíneas temperadas. Esses resultados aproximaram-se daqueles encontrados por BETTERIDGE et al. (1994), que indicaram intensidades de $43 \%$ para ovinos e de $52 \%$ para bovinos, ambos alocados em pastagens naturais de plantas forrageiras temperadas.

A diferença entre os valores apresentados por diferentes autores estaria mais relacionada a características intrínsecas das plantas forrageiras estudadas e aos métodos de pastejo adotados, fatores determinantes da plasticidade fenotípica das plantas forrageiras, ou seja, de sua capacidade de adaptação æ̀̀ condições impostas objetivando limitar o impacto do manejo sobre sua taxa de crescimento (HODGSON et al., 1981). Contudo, o manejo aplicado tem forte influência sobre a composição botânica do relvado, conseqüência da busca pelas plantas de uma nova condição de equilíbrio (BROUGHAM, 1960). Mudanças morfológicas no relvado têm efeito importante sobre a taxa de crescimento através de sua influência na habilidade das 
plantas de produzir novas folhas (GRANT \& KING, 1983). Toda alteração nas características morfológicas da planta forrageira são condicionadoras de sua intensidade de desfolhação (LEMAIRE \& CHAPMAN, 1996).

Pesquisadores como BARTHRAM \& GRANT (1984) e CHACON \& STOBBS (1976) relataram que a partir do momento em que o rebaixamento do relvado atinge camadas onde há maior proporção de bainhas e hastes, ocorre decréscimo da intensidade de desfolhação em função da limitação física imposta pelas hastes e bainhas. A densidade de lotação adotada e a duração do período de pastejo também interferem diretamente na intensidade de desfolhação, e ambas características derivam do método de pastejo empregado (LEMAIRE \& CHAPMAN, 1996).

A intensidade de desfolhação influencia a eficiência fotossintética das folhas nos primeiros estágios da rebrotação. Desfolhações intensas levam a menor eficiência inicial das folhas que, após determinado tempo, demonstram as maiores eficiências (BROUGHAM, 1956). BROUGHAM (1956) e PARSONS et al. (1988) alertaram que quanto mais intensa a desfolhação, menor a taxa inicial de rebrotação e maior o tempo necessário para que a planta atinja a máxima eficiência fotossintética e, consequentemente, a máxima taxa de crescimento. PARSONS et al. (1988) e PARSONS \& PENNING (1988) acrescentaram que, em condições de maior intensidade de desfolhação, a taxa instantânea de acúmulo inicial é lenta e eleva-se rapidamente. No entanto, quando considera-se a taxa média de acúmulo de forragem, esta pouco se altera, mantendo-se em níveis elevados após o valor máximo ter sido atingido. No caso de intensidades de desfolhação intermediárias, altas taxas de acúmulo médio também são obtidas, porém por período menor de tempo. Nas pastagens que sofrem desfolhações pouco intensas, as taxas de acúmulo são menores e acabam por declinar com o tempo.

Segundo HODGSON et al. (1981), incrementos na intensidade de desfolhação de uma pastagem resultaram em redução do comprimento da pseudo-haste (bainha) e redução do ângulo de perfilhos e folhas de azevém perene, resultando num crescimento mais prostrado. GOMIDE \& GOMIDE (1999) mencionaram que a adoção de intensidades maiores de desfolhação pode contribuir para prevenir o intenso alongamento do colmo, processo muito precoce e comum em gramíneas tropicais, melhorando, assim, a relação folha:haste da forragem presente na pastagem. 
BIRCHAM \& HODGSON (1983), BROUGHAM (1959), HODGSON (1990) e LEMAIRE \& CHAPMAM (1996) descreveram a influência da intensidade de desfolhação sobre a densidade populacional de perfilhos, indicando que incrementos na intensidade promovem redução no tamanho de perfilhos individuais e aumento em seu número total. HU (1993) ponderou que embora muitos pontos de crescimento tenham sido removidos em situações de desfolhações mais intensas, foi exatamente nessas circunstâncias que as maiores taxas de aparecimento de perfilhos foram observadas. Por outro lado, BROUGHAM (1960) enfatizou que as maiores populações de perfilhos são verificadas em intensidades de desfolhação intermediárias, considerando que a desfolhação extremamente intensa passa a prejudicar a emissão de novos perfilhos, podendo causar, inclusive, a morte de plantas.

\subsubsection{2 - Freqüência de desfolhação}

BOOTSMA (1990), HODGSON (1990) e WADE (1991) definiram freqüência de desfolhação como o número de desfolhações que uma folha ou perfilho sofre num dado período de tempo, normalmente expressa em número de desfolhações por dia. Entretanto, é comum observar trabalhos onde ao invés de adotar a freqüência de desfolhação os autores citam seu inverso, que indica o intervalo de tempo entre desfolhações sucessivas.

HODGSON (1990) relatou que um relvado é rebaixado em camadas, ou seja, os animais primeiro removem as porções mais elevadas do dossel para, numa seqüência de bocados seguinte, remover camadas inferiores. Portanto, um mesmo perfilho ou folha pode ser pastejado mais de uma vez ao longo de um ciclo de pastejo. Com base nessas informações, LEMAIRE \& CHAPMAN (1996) relataram que, em regimes de lotação intermitente, a freqüência de desfolhação aparece estritamente ligada ao intervalo entre os ciclos de desfolhações (período de descanso) que, por sua vez, são determinados pelo conjunto de práticas de manejo do pastejo.

A freqüência de desfolhação guarda íntima relação com a densidade de lotação empregada tanto em regimes de lotação contínua como de lotação intermitente (WADE, 1991). Quando expressa na forma de porcentagem, num regime de lotação contínua, corresponde à proporção de perfilhos pastejados por dia que, por sua vez, é semelhante à proporção da área do relvado sendo pastejada diariamente pelos 
animais (WADE et al., 1989). Para o caso de lotação contínua, BARTHRAM \& GRANT (1984) e HODGSON (1966) e relatando sobre azevém perene, indicaram que a área pastejada diariamente equivalia a intervalos entre desfolhações de 5 a 16 dias conforme a densidade de lotação aplicada no sistema. Esses valores implicam em freqüências de desfolhação variando entre 0,06 e 0,20 desfolhação.perfilho-1 ${ }^{-1}$.dia ${ }^{-1}$, ou seja, 6 e 20\% da área sendo pastejada diariamente. HODGSON (1990) acrescentou que quando animais têm acesso a amplas áreas de pasto e as taxas de produção de forragem e de consumo estão próximas da igualdade, perfilhos individuais ou grupos de perfilhos são desfolhados a intervalos de 3 a 4 semanas (freqüência de 0,03 a 0,05 desfolhação.perfilho ${ }^{-1} \cdot$ dia $^{-1}$ ) sob densidade de lotação relativamente reduzida, até menos de 5 a 6 dias (freqüência de 0,16 a 0,20 desfolhação.perfilho ${ }^{-1}$.dia ${ }^{-1}$ ) quando a densidade de lotação é elevada. Em regimes de lotação contínua, quanto maior a densidade de lotação mais freqüentes são as desfolhações, ou seja, maior o número de vezes que um perfilho é visitado pelo agente desfolhador num determinado intervalo de tempo (HODGSON, 1990; WADE, 1991).

Com o objetivo de estudar o efeito de variáveis do manejo do pastejo sobre a freqüência de desfolhação de perfilhos individuais, WADE (1991) avaliou três métodos de pastejo distintos: (a) pastejo em faixas, (b) pastejo rotacionado, (c) lotação contínua. Os resultados obtidos possibilitaram concluir que as relações entre freqüência de desfolhação e densidade de lotação verificadas por WADE \& BAKER (1979) para lotação contínua também foram válidas para os casos de lotação intermitente (pastejo rotacionado e em faixas). Sob lotação intermitente, a área pastejada diariamente foi equivalente a intervalos de desfolhação de 5 a 16 dias (freqüências entre 0,06 e 0,20 desfolhação.perfilho-1 ${ }^{-1}$.dia ${ }^{-1}$ ), valores dentro dos já mencionados para lotação contínua. É interessante observar que apesar do manejo aparentemente contrastante, os métodos de lotação intermitente e contínua apresentaram comportamento semelhante (WADE, 1991).

Segundo LEMAIRE \& CHAPMAN (1996), nos casos onde a lotação intermitente é adotada, a freqüência de desfolhação é determinada pela freqüência com que se move os animais de um piquete para outro que, por sua vez, é função do tamanho do piquete, número de piquetes, taxa de acúmulo de forragem e do número de animais. Portanto, para lotação intermitente a freqüência de desfolhação acaba sendo 
determinada pelo ciclo de pastejo empregado (período de ocupação + período de descanso).

BARTHRAM \& GRANT (1984), em estudo onde incluíram a idade das folhas na avaliação da freqüência de desfolhação, perceberam que havia variação conforme o posicionamento das mesmas ao longo do perfil do dossel, sendo desfolhadas com maior freqüência aquelas situadas no topo do mesmo. Resultados semelhantes foram obtidos por MAZZANTI \& LEMAIRE (1994) em estudo com festuca, onde foram verificados intervalos entre desfolhações de 17, 15 e 27 dias, equivalentes a freqüências de 0,06, 0,07 e 0,04 desfolhação.perfilho ${ }^{-1}$.dia ${ }^{-1}$, respectivamente, para folhas classificadas como novas, intermediárias e velhas.

À medida que a freqüência de desfolhação aumenta, ocorre uma elevação na população de perfilhos e, nessa situação, maior densidade populacional de perfilhos é percebida em situações de lotação contínua quando comparadas a situações de lotação intermitente para uma mesma densidade de lotação (HODGSON \& WADE, 1978). Adubações nitrogenadas influem indiretamente na freqüência de desfolhação de perfilhos individuais devido a seu efeito positivo sobre o crescimento da planta forrageira, que leva a uma necessidade de aumentar a densidade de lotação para manutenção das condições e controle da estrutura do relvado (MAZZANTI \& LEMAIRE, 1994). É essa maior densidade de lotação que acaba por elevar a freqüência de desfolhação observada naquelas circunstâncias.

BROUGHAM (1956) verificou que desfolhações muito freqüentes levaram a redução da produção de massa seca da planta pela diminuição da área foliar disponível para interceptação de luz e realização de fotossíntese. Entretanto, essa menor produção foi compensada, dentro de um determinado limite característico de cada planta forrageira, por uma maior participação de folhas novas na dieta dos animais, ficando o material pastejado com maior valor nutritivo (BROUGHAM, 1959). Já nas situações onde a freqüência de desfolhação foi mais baixa, o valor nutritivo da forragem decresceu.

Desfolhações freqüentes podem resultar em crescimento mais lento da pastagem, uma vez que reduzem efetivamente a oportunidade para restabelecimento pleno dos níveis originais de reservas orgânicas da planta forrageira (LEMAIRE \& CHAPMAN, 1996). Contudo, a alta disponibilidade de luz na base de pastos mantidos em valores de IAF baixos, associada ao aumento na proporção de folhas novas em 
relação às velhas, resulta num aumento de eficiência fotossintética por unidade de área foliar (WOLEDGE, 1977). A qualidade da luz propicia o início da formação de novas estruturas, principalmente folhas, garantindo a produção de massa seca, seja por perfilho ou por área.

Com base nesses princípios, DA SILVA \& PEDREIRA (1997) comentaram que em sistemas consorciados, onde a freqüência de desfolhação é elevada, a planta com maior proporção de IAF na parte inferior do dossel apresenta o maior IAF residual, o que assegura uma rápida recuperação inicial após a desfolhação através de uma interceptação luminosa eficiente. Em contrapartida, se o período de rebrota é longo, as plantas de crescimento mais alto e ereto, com maiores proporções de IAF nas regiões intermediária e superior do dossel, têm tempo suficiente para acumular um grande IAF sendo, portanto, mais produtivas.

\subsubsection{3 - Eficiência de pastejo}

A produtividade de uma gramínea forrageira é função da contínua emissão de folhas e perfilhos, processo importante após corte ou pastejo para a restauração da área foliar que garante à planta forrageira sua perenidade (GOMIDE, 1997). Entretanto, somente informações relativas ao crescimento não são suficientes para aferir conceitos ou formas de utilização da pastagem. A dinâmica de crescimento está relacionada a outros processos que ocorrem simultaneamente numa situação de equilíbrio. Considerando o tempo limitado de vida das folhas, após determinado tempo elas invariavelmente entram em processo de senescência (PINTO, 2000). Dessa forma, todo material não colhido ou não pastejado é logo perdido através do processo de senescência (BULLOCK, 1996), e constitui perdas potenciais de produção (HODGSON, 1990). Trabalhando com gramíneas tropicais, CHACON \& STOBBS (1976) concluíram que a taxa de consumo de forragem dependia da quantidade e do acesso à fração folhas vivas. Esse fato foi reforçado por JACQUES (1974), que demonstrou que o acúmulo de material morto em pastagens submetidas a pastejo leniente poderia incorrer em sua rejeição por parte dos animais, aumentando ainda mais as perdas de forragem.

A eficiência de utilização de forragem em sistemas de pastejo é definida como a proporção da forragem produzida que é colhida pelos animais em pastejo antes que 
inicie o processo de senescência (HODGSON, 1990). Assim, a eficiência de utilização é função da proporção do comprimento da lâmina foliar que escapa do pastejo e senesce (LEMAIRE \& CHAPMAN, 1996). Em termos práticos, de nada adianta um elevado crescimento da planta forrageira se o mesmo estiver associado a altas perdas de material por senescência e uma baixa eficiência de utilização.

Conforme já demonstrado, logo após a desfolhação ocorre a emissão de novas folhas, aumento rápido da fotossíntese e consequentemente da capacidade de produção de forragem. Durante a fase de rebrotação existe um certo atraso entre crescimento e senescência foliar, ou seja, existem momentos onde altas taxas de produção de tecido estão associadas a baixas taxas de senescência e morte de tecidos, gerando uma taxa média máxima de acúmulo de massa seca no pasto (HODGSON et al., 1981). O manejo do pastejo é, na sua essência, o compromisso entre a necessidade de se manter área foliar suficiente para a realização da fotossíntese e a de se colher grandes quantidades de tecido foliar de alta qualidade antes desse tecido morrer (PARSONS, 1988). Nesse contexto, para obter a máxima eficiência de colheita, o ideal seria colher a planta forrageira durante a fase em que ela apresenta a máxima taxa média de acúmulo de forragem (HODGSON, 1990; LEMAIRE \& CHAPMAN, 1996).

Toda vez que se busca a máxima eficiência de utilização da produção vegetal (densidade de lotação elevada) incorre-se numa retração da eficiência de conversão alimentar e, consequentemente, no desempenho individual dos animais. Tal fato é conseqüência de redução da oferta de forragem e da oportunidade de seleção durante o pastejo, resultando em menor quantidade de material ingerido com menor valor nutritivo (HODGSON, 1990; BRISKE, 1996). O inverso também acontece, ou seja, ao buscar o máximo desempenho animal individual (densidade de lotação baixa), é promovido um aumento nas sobras de forragem e, com isso, nas perdas de material por senescência (HODGSON, 1990). A otimização da produção de pastagens não deve ser concebida, portanto, como a maximização da quantidade de forragem produzida ou somente consumida pelos animais pura e simplesmente, mas como o resultado do compromisso entre os três processos de fluxo de tecidos especialmente relacionados æ̀ folhas: crescimento, senescência e consumo (DA SILVA \& SBRISSIA, 2000; MOTT, 1961; PARSONS, 1994). 
HODGSON (1981) relatou que o consumo de forragem é maximizado quando a oferta é de 3 a 4 vezes a capacidade de ingestão do ruminante. Assim, um consumo voluntário de $2,5 \%$ do peso vivo do animal ocorre sob condições de oferta diária de forragem da ordem de 7,5 a $10 \%$ do peso vivo animal. Por sua vez, LEAFE \& PARSONS (1983) mencionaram que na prática a eficiência de colheita de pastagens de gramíneas acaba sendo esquecida em função da constante busca por altos valores de desempenho animal resultando, na maioria das vezes, numa baixa produção animal por hectare e um excesso de perda de forragem por senescência. GOMIDE \& GOMIDE (1999) afirmaram que a utilização eficiente da forragem produzida depende da adoção de densidade de lotação compatível com a capacidade de suporte da pastagem e com o desempenho animal esperado.

MAZZANTI \& LEMAIRE (1994) demonstraram que a proporção do comprimento da lâmina foliar que escapa do pastejo e eventualmente senesce pode ser estimada a partir da proporção entre o tempo de vida das folhas e o intervalo entre desfolhações, determinando o número máximo de vezes que uma folha pode ser desfolhada durante o seu período de vida. LEMAIRE \& CHAPMAN (1996) acrescentaram que para um dado tempo de vida de uma folha qualquer, sua utilização seria máxima quanto maior o número de desfolhações possíveis nesse período (freqüência), e quanto maior a proporção da lâmina foliar retirada a cada desfolhação (intensidade).

HODEN et al. (1991) afirmaram que o volume de forragem pastejado por dia pode ser calculado como sendo o produto entre profundidade de pastejo (intensidade de pastejo) e área pastejada, ambas dependentes da densidade de lotação empregada. Somando a essas informações dados relativos a densidade do relvado, é possível, ainda, estimar a quantidade de forragem removida pelo animal por dia. WADE (1991) relatou em seu estudo com vacas leiteiras que as características que mais influenciaram a taxa máxima diária de remoção de forragem (eficiência de colheita) foram a altura estendida do perfilho e a densidade volumétrica da forragem ao longo do perfil do dossel forrageiro.

Em sistemas que adotam a lotação contínua, as maiores produtividades seriam obtidas através da manutenção de valores baixos de IAF (PARSONS et al., 1988) como resultado da elevação da densidade populacional de perfilhos e aumento da relação folha verde:haste (HODGSON et al., 1977). Nessas situações, uma grande proporção do tecido produzido é efetivamente colhida pelo pastejo, embora as taxas de 
fotossíntese e de produção bruta de forragem (crescimento) sejam menores que seus máximos. Em lotação contínua, a quantidade de tecido perdido por senescência e morte pode ser menor, porém, quando a lotação intermitente imprime uma desfolhação intensa, proporções equivalentes da produção bruta são colhidas em ambos os sistemas (PARSONS, 1988), indicando não haver qualquer vantagem óbvia de um método de pastejo sobre o outro (DA SILVA \& PEDREIRA, 1997).

LEMAIRE \& AGNUSDAI (1999) comentaram que no caso de lotação contínua, onde a freqüência é livre, a probabilidade de uma folha ser pastejada antes de senescer está relacionada com a densidade de lotação e proporção de tecido vivo removido pelo pastejo, ou seja, uma combinação entre intensidade e freqüência de desfolhação. PARSONS et al. (1988) demonstraram que alta eficiência de colheita não pode estar associada a altas taxas de fotossíntese e de produção de forragem, uma vez que é obtida através de desfolhações freqüentes e intensas. O mau dimensionamento e planejamento do processo de desfolhação, especialmente quando se busca otimizar a colheita de forragem, pode provocar queda na produção e no vigor das plantas, uma vez que uma seqüência de desfolhações de alta intensidade e freqüência pode causar redução da interceptação luminosa, esgotamento de reservas metabólicas, redução da absorção de nutrientes e água, além de danos ao meristema apical (LEMAIRE \& AGNUSDEI, 1999).

Em lotação intermitente, uma intensidade maior de desfolhação acaba por contribuir diretamente para uma utilização mais eficiente da forragem disponível durante o período de pastejo e, indiretamente, para redução das perdas por senescência e morte de folhas no período de descanso (rebrotação) subseqüente ao pastejo (GOMIDE \& GOMIDE, 1999). Ao empregar-se uma baixa densidade de lotação, um maior número de folhas escapa ao pastejo reduzindo a eficiência de utilização da pastagem, afetando negativamente a relação folha:haste do dossel forrageiro e prejudicando os pastejos subseqüentes (HODGSON, 1990). Considerando esses fatos, a duração média dos períodos de descanso deve ser ajustada de forma a minimizar a perda de tecidos foliares por meio da senescência (menor que o período de vida útil da folha), e os períodos de pastejo e densidade de lotação devem ser suficientes para colheita da maior proporção possível da forragem produzida. Dessa forma pode ser possível manter uma alta eficiência de utilização da forragem apesar da redução nas taxas de crescimento (HODGSON, 1990). BIRCHAM \& HODGSON (1983) 
postularam que ao imprimir desfolhações mais freqüentes e intensas, seja por corte ou pastejo, geralmente ocorre redução no crescimento da pastagem, porém nem sempre isso leva à redução da quantidade de forragem colhida. A redução no crescimento provocada por desfolhações freqüentes e intensas pode ser total ou parcialmente compensada pela melhor utilização (aproveitamento) através da redução das perdas por senescência da forragem não colhida.

MAXWELL \& TREACHER (1987) verificaram que considerando a duração média de vida das folhas de azevém perene de 33 dias, quando o relvado era manejado alto (9 e $12 \mathrm{~cm}$ ), ocorria redução da freqüência de desfolhação a ponto de uma grande proporção das folhas acabar senescendo sem ter sido pastejada. Nas situações de relvado manejado baixo (3 e $6 \mathrm{~cm}$ ), a freqüência de desfolhação foi maior e uma maior proporção das folhas produzidas foi colhida através do pastejo antes da manifestação dos efeitos da senescência. MAZZANTI \& LEMAIRE (1994) estimaram uma máxima eficiência de utilização teórica da forragem produzida para festuca com base na remoção de uma proporção relativamente constante do comprimento da folha de 50\% (intensidade de desfolhação), um intervalo médio entre desfolhações de 20 dias (equivalente a uma freqüência de 0,05 desfolhação.perfilho ${ }^{-1}$.dia ${ }^{-1}$ ) e uma vida útil das folhas de 40 dias. Esses valores combinados indicaram que cada folha estaria sujeita a duas desfolhações possíveis durante seu período de vida e que a cada desfolhação $50 \%$ do comprimento da folha seria removido, originando uma eficiência teórica de colheita de $75 \%$. Os mesmos autores confirmaram essa expectativa teórica através de um experimento de campo, onde encontraram uma eficiência de utilização efetiva de $73 \%$ para festuca manejada sob lotação contínua.

\section{5 - DINÂMICA DA DESFOLHAÇÃO DE PLANTAS FORRAGEIRAS}

A dinâmica da desfolhação de plantas forrageiras está sujeita a interações de diversas naturezas, cabendo ao manejador do sistema equacionar todas essas interações e elaborar uma estratégia de desfolhação condizente com a planta forrageira sendo explorada e as metas de produtividade almejadas. Essa estratégia de manejo assume maior importância quando considerada a afirmação de HODGSON et al. (1981) de que mudanças mais significativas ocorrem dentro da relação de 
aproveitamento da forragem (produzido $\mathrm{x}$ colhido $\mathrm{x}$ senescido) que dentro da produção total da mesma, sob diferentes condições de intensidade e freqüência de desfolhações.

Aspectos relacionados ao hábito de crescimento da planta forrageira devem ser observados. De acordo com BROUGHAM (1959), diversos trabalhos demonstraram que incrementos na freqüência de desfolhação levaram à redução na produção de massa seca no caso de plantas de crescimento ereto, ocorrendo o inverso em plantas de crescimento prostrado. Isso levou muitos técnicos a encorajar o uso de práticas de desfolhações mais freqüentes e intensas para plantas de crescimento prostrado e desfolhações menos freqüentes e intensas para aquelas de crescimento ereto. Em seus estudos, esse autor verificou que o azevém perene, com seu hábito de crescimento rasteiro, suportou melhor desfolhações intensas e freqüentes, respondendo em produção. Em contrapartida, o trevo-vermelho, com hábito de crescimento ereto, apresentou melhor desempenho com desfolhações menos intensas. Já o trevo-branco, de crescimento prostrado, demonstrou maior produção sob desfolhação freqüente. Porém, BROUGHAM (1959) reiterou que deve haver cuidado com as generalizações. Na verdade, a capacidade da planta de suportar uma desfolhação freqüente e intensa deriva de sua habilidade em suportar o pastejo e rebrotar rapidamente.

Outro ponto importante diz respeito æ̀ variações de resposta conforme a estação climática e as interações entre as diferentes combinações de freqüência e intensidade de desfolhação ao longo dessas estações. Nesse sentido, BROUGHAM (1960) testou diferentes combinações de freqüência e intensidade de desfolhação ao longo do ano com o objetivo de encontrar a melhor combinação, nas diferentes estações, que permitisse a máxima produção e aproveitamento da forragem. Com base em seus estudos com diversas plantas forrageiras, concluiu que: (a) desfolhações freqüentes durante o inverno levaram a maior produção de massa seca; (b) durante a primavera, as desfolhações menos intensas levaram a maior produção, sem diferença aparente para variação na freqüência; (c) no período de verão, produções maiores foram obtidas em pastos desfolhados com menor intensidade, e aqueles pastos que sofreram desfolhações mais intensas durante o inverno demonstraram maior produção, não havendo diferenças com relação a uma desfolhação intensa na primavera; (d) no outono, a produção total dos pastos submetidos a desfolhações mais intensas no verão foi menor que a dos demais; (e) a maior produção anual foi obtida em situações de 
desfolhação mais intensa no inverno, seguida de desfolhação menos intensa ao longo do resto do ano e a menor produção quando a desfolhação intensa ocorreu durante a primavera e/ou durante o verão.

Em trabalho anterior, BROUGHAM (1959) buscou encontrar a combinação entre freqüência e intensidade de desfolhação ao longo do ano que permitisse a maior produção de forragem durante o inverno, objetivando reduzir a estacionalidade de produção de forragem. Encontrou que o manejo mais indicado para esse caso seria combinar as características desejáveis de uma desfolhação menos intensa na primavera, verão e início do outono com uma desfolhação mais intensa no final do outono. Dessa maneira, maiores produções seriam obtidas durante os meses de inverno.

Já PARSONS et al. (1991a), em estudo onde um relvado de azevém perene era mantido em alturas relativamente constantes de 3, 6 e $9 \mathrm{~cm}$, verificaram que a desfolhação foi menos intensa durante o outono que na primavera em virtude da menor densidade de lotação abrigada no outono. Durante a primavera as folhas do tratamento mais baixo foram desfolhadas com maior intensidade que a dos relvados mais altos. Já no outono, os dois tratamentos mais baixos apresentaram comportamento similar e foram mais intensamente desfolhados que o tratamento mais alto.

BROUGHAM (1956 e 1958) demonstrou em seus trabalhos que a intensidade da desfolhação exerceu efeito sobre a restauração da área foliar do dossel e, consequentemente, sobre a interceptação de luz. Quando relvados de azevém perene mantidos a alturas médias de $22 \mathrm{~cm}$ foram rebaixados a diferentes alturas através de corte, o tempo necessário para que a pastagem restaurasse sua área foliar a ponto de interceptar $95 \%$ da luz incidente foi de 24, 16 e 4 dias para as alturas de rebaixamento de 12,5, 7,5 e 2,5 cm, respectivamente. O mesmo padrão de respostas foi observado por PARSONS et al. (1988), que afirmaram que, de uma maneira geral, para obter a taxa média máxima de acúmulo, desfolhações mais intensas deveriam ser associadas a longos períodos de rebrotação, e desfolhações menos intensas associadas a curtos períodos de rebrotação.

HODGSON (1984) comentou que tanto a massa seca residual quanto a oferta de forragem são bons parâmetros para tomadas de decisão de manejo. Entretanto, algumas considerações sobre sua aplicabilidade devem ser feitas. Evidências da oferta de forragem e da massa seca residual em pastagens estabilizadas podem, até certo 
ponto, ser mascaradas por efeitos da composição botânica do relvado e de sua estrutura. Esses pontos adquirem maior relevância quando é preconizado o máximo rendimento através do máximo desempenho animal na pastagem. Nessas circunstâncias, as eficiências de utilização estariam entre 25 a 30\%, resultando num elevado nível de perda de forragem, declínio do valor nutricional da forragem (folhas mais velhas e maior participação de hastes), e redução no vigor do relvado.

BIRCHAM \& HODGSON (1983), em estudo com diferentes plantas forrageiras submetidas a lotação contínua com carga variável por ovinos e fazendo uso da oferta de forragem como precursor das práticas de manejo, verificaram que o melhor desempenho da pastagem foi obtido numa oferta de forragem de $1250 \mathrm{~kg}$ de massa seca por hectare. Perceberam, ainda, que os resultados variaram pouco entre $1000 \mathrm{a}$ $2000 \mathrm{~kg}$ de massa seca por hectare, em virtude do gradual incremento na taxa de senescência que acabou por equilibrar a taxa de produção de forragem, resultando num acúmulo relativamente constante de forragem dentro dessa amplitude de oferta.

Com base no exposto, fica aparente a íntima relação entre as respostas de plantas (produção de forragem) e animais (consumo e desempenho) quando considerados aspectos relativos a estrutura do dossel forrageiro. Assim, esforços no sentido de descrever e compreender aspectos da interface planta:animal assumem importância significativa e papel estratégico no planejamento de práticas de manejo e produção animal em ecossistemas de pastagens. 


\section{MATERIAL E MÉTODOS}

\section{1 - MATERIAL}

\subsection{1 - Espécie vegetal}

A espécie forrageira utilizada foi a Brachiaria brizantha (Hochst ex A. Rich) Stapf cultivar Marandu, em função de seu elevado potencial produtivo, grande interesse por parte dos pecuaristas, e representatividade nas pastagens cultivadas no território nacional.

Existem diversas denominações regionais para essa planta forrageira, podendo ser conhecida como: Brizantão, Brizanta, Braquiarão, capim Marandu, capim Ocinde, e Marandu (RENVOIZE et al., 1998). Para facilidade de redação, o nome utilizado deste ponto em diante será capim Marandu.

\subsubsection{1 - Origem}

De acordo com NUNES et al. (1985), o capim Marandu é um ecotipo da Brachiaria brizantha, originário de regiões vulcânicas da África tropical, que durante muitos anos foi cultivado no Brasil, na região do município de Ibirarema, Estado de São Paulo. Em 1977 a Estação de Pesquisas em Pastagens de Marandela - Zimbabwe, na África, enviou amostras do material vegetal ao CNPGC - Centro Nacional de Pesquisa de Gado de Corte, da EMBRAPA - Empresa Brasileira de Pesquisa Agropecuária, situado no município de Campo Grande, Estado do Mato Grosso do Sul, onde passou a ser estudado sob o código de acesso BRA-000591. No ano de 1979 o CPAC Centro de Pesquisa Agropecuária do Cerrado, também da EMBRAPA, situado no município de Planaltina, Distrito Federal, recebeu parte do material para estudo. No 
ano de 1984 houve o lançamento oficial da planta forrageira, numa parceria entre o CPAC e o CNPGC, servindo esta como mais uma alternativa forrageira aos pecuaristas brasileiros (NUNES et al., 1985; RENVOIZE et al., 1998).

\subsubsection{2 - Características gerais}

O cultivar Marandu chamou a atenção dos técnicos pelas suas características específicas como: plantas sempre robustas, hábito de crescimento cespitoso, altura de 1,5 a 2,5 metros, colmos iniciais de crescimento prostrado, mas com emissão de perfilhos predominantemente eretos. Seus rizomas são muito curtos e encurvados. Os colmos floríferos são eretos, com perfilhamento nos nós superiores, levando à proliferação de inflorescências que atingem até 40 centímetros de comprimento, geralmente com 4 a 6 racemos. Suas lâminas foliares são largas e longas, glabras na face superior, com pubescência na face inferior, e bordos não cortantes. As bainhas são pilosas, enquanto os entrenós apresentam pêlos na porção apical (NUNES et al., 1985). Sua capacidade de adaptação \&̀s mais variadas condições de ambiente (GHISI \& PEDREIRA, 1987), especialmente em sistemas de produção com reduzido emprego de insumos, é a responsável por sua expansão e expressividade (ANDRADE, 1994). Segundo SANTOS FILHO (1996), é uma das plantas forrageiras mais utilizadas em todo o país, perfazendo mais de $20 \%$ de todas as pastagens cultivadas (MACEDO, 1995).

SOARES FILHO (1994) mencionou que esse cultivar adapta-se a condições de até 3.000 metros de altitude, precipitação pluvial anual ao redor de $700 \mathrm{~mm}$ e cerca de 5 meses de seca no inverno. No entanto, não suporta solos encharcados. É recomendado para áreas de média a boa fertilidade, embora tolere acidez no solo. Melhores resultados foram observados em solos ondulados a fortemente ondulados e profundos. A temperatura ótima para seu desenvolvimento está entre 30 e $35^{\circ} \mathrm{C}$, sendo a mínima de $15^{\circ} \mathrm{C}$, embora tolere bem geadas (SKERMAN \& RIVEROS, 1992). Apresenta reduzida tolerância ao sombreamento, desenvolvendo-se abundantemente a sol pleno. O cultivar Marandu, em especial, suporta bem o fogo (GHISI \& PEDREIRA, 1987). 


\subsubsection{3 - Potencial produtivo}

O capim Marandu apresenta elevado potencial de produção de massa verde, sendo muito usado na alimentação de ruminantes em geral e, ao contrário de outras braquiárias, é bem aceito por eqüínos (SOARES FILHO, 1994). Apesar de tolerante a condições adversas, é extremamente responsivo a adubações, podendo ser encontradas produções bastante elevadas de até 36 toneladas de massa seca por hectare por ano, segundo relatos de GHISI \& PEDREIRA (1987).

\subsection{2 - Local do experimento}

\subsubsection{1 - Localização geográfica}

O local de condução do experimento foi a Unidade Experimental de Plantas Forrageiras (UEPF), área coordenada pelo Grupo de Estudos de Plantas Forrageiras (GEPF) do Departamento de Zootecnia, da Escola Superior de Agricultura "Luiz de Queiroz", pertencente àUniversidade de São Paulo (Figura 1).

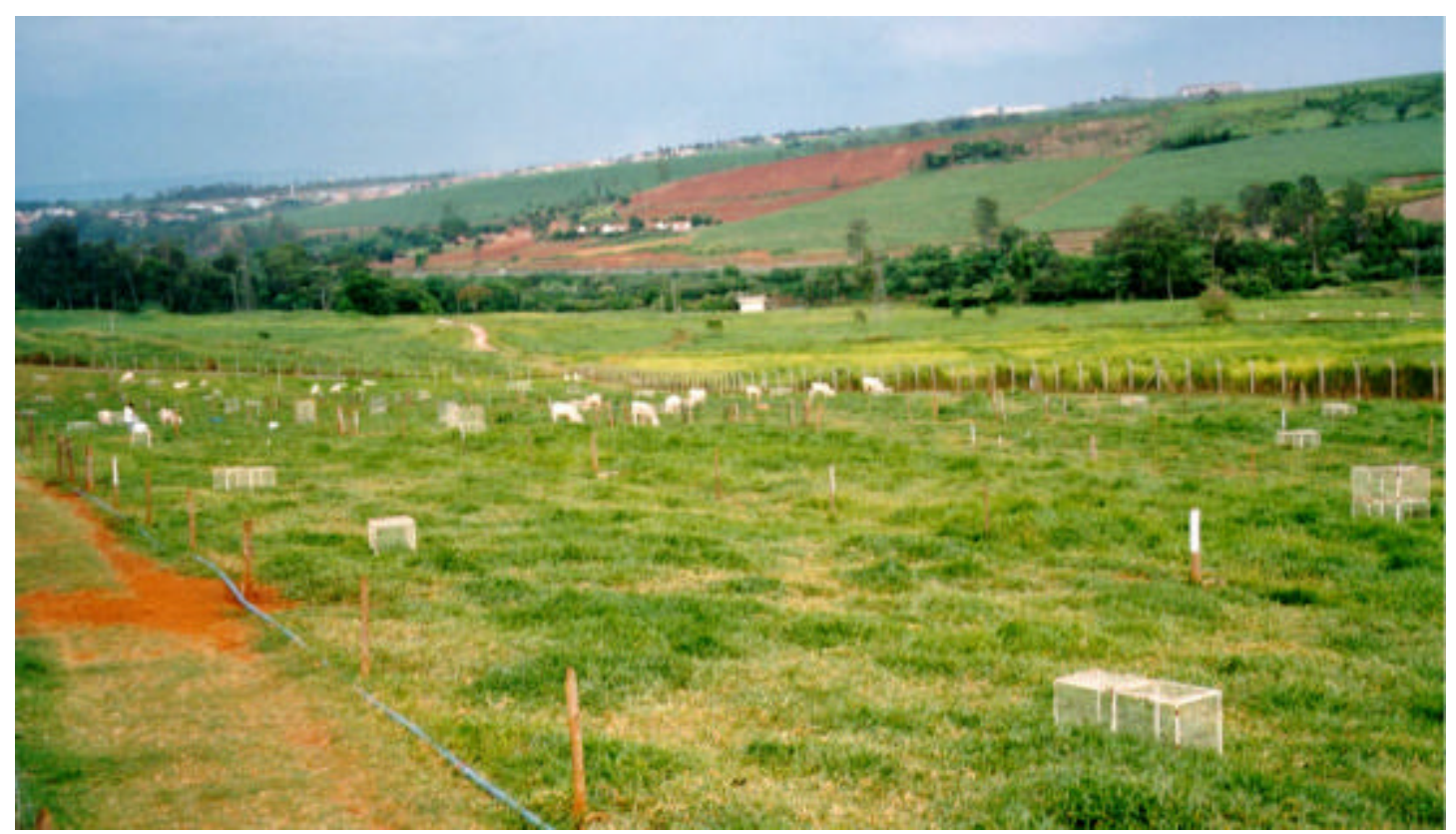

Figura 1 - Fotografia da vista geral da área experimental do GEPF. 
A referida área está situada no município de Piracicaba, SP, sob as

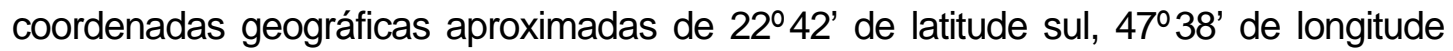
oeste, e 546 metros de altitude (OMETO, 1989).

\subsection{3 - Solo da área experimental}

O solo da área experimental é classificado como Nitrossolo Vermelho eutroférrico, com horizonte A moderado e textura variando de argilosa a muito argilosa (EMBRAPA, 1999). Antes do estabelecimento dos pastos de capim Marandu, foram realizadas amostragens para fins de avaliação de fertilidade do solo em todas as unidades experimentais. Os resultados podem ser verificados na Tabela 1.

Tabela 1. Resultado da análise química do solo da área experimental

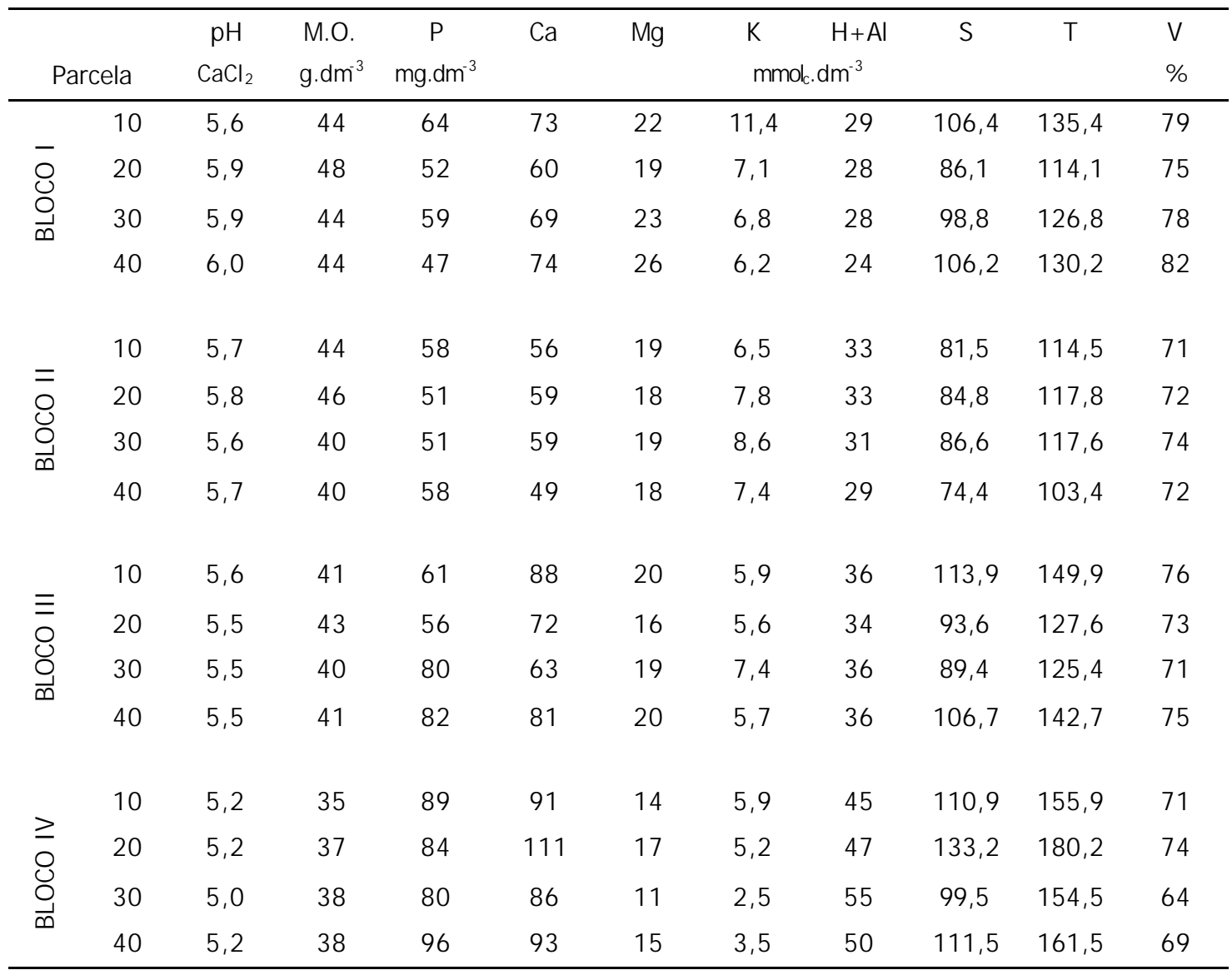


De acordo com RAIJ et al. (1996), os resultados encontrados demonstram a elevada fertilidade da área experimental, motivo que levou àsupressão das calagens e adubações potássicas e/ou fosfatadas para correção do solo no momento da semeadura e estabelecimento da planta forrageira.

\subsection{4 - Clima}

\subsubsection{1 - Classificação}

De acordo com o sistema Köppen, o clima na região de Piracicaba é caracterizado como mesotérmico úmido, subtropical de inverno seco, classificado como Cwa, com temperaturas médias inferiores a $18^{\circ} \mathrm{C}$ no mês mais frio e superiores a $22^{\circ} \mathrm{C}$ na época mais quente (BRASIL, 1960).

\subsubsection{2 - Dados do período de amostragem}

Os dados climáticos referentes ao período experimental foram coletados no posto meteorológico do Departamento de Ciências Exatas da Escola Superior de Agricultura "Luiz de Queiroz", Universidade de São Paulo, situado a cerca de 500 metros da área experimental (Tabelas 2 e 3). Houve uma ligeira deficiência hídrica no início de dezembro e outra, pouco mais acentuada, em meados de fevereiro. Ambas deficiências foram leves e representaram pouco para a produtividade das pastagens. 
Tabela 2. Radiação solar global, insolação diária, precipitação total e temperaturas médias mensais do ar (mínima, média e máxima) durante o período experimental.

\begin{tabular}{|c|c|c|c|c|c|c|c|}
\hline \multicolumn{2}{|c|}{ Época } & \multirow{2}{*}{$\begin{array}{l}\text { Precipitação } \\
\text { Total } \\
\text { mm }\end{array}$} & \multicolumn{3}{|c|}{ Temperatura Média (으) } & \multirow{2}{*}{$\begin{array}{l}\text { Insolação } \\
\text { Diária } \\
\text { horas.dia }{ }^{-1}\end{array}$} & \multirow{2}{*}{$\begin{array}{c}\text { Radiação } \\
\text { Global } \\
\text { cal.cm². dia- }\end{array}$} \\
\hline Mês & Ano & & Mínima & Média & Máxima & & \\
\hline \multirow{2}{*}{ Outubro } & 2001 & 173,3 & 16,1 & 22,8 & 29,5 & 7,9 & 496 \\
\hline & média 84 anos & 111,1 & 15,6 & 22,3 & 28,9 & 6,9 & 438 \\
\hline \multirow{2}{*}{ Novembro } & 2001 & 152,4 & 18,7 & 24,7 & 30,7 & 6,7 & 466 \\
\hline & média 84 anos & 130,6 & 16,7 & 23,1 & 29,6 & 7,4 & 474 \\
\hline \multirow{2}{*}{ Dezembro } & 2001 & 204,2 & 18,7 & 24,0 & 29,2 & 5,4 & 427 \\
\hline & média 84 anos & 201,0 & 18,2 & 23,9 & 29,6 & 6,6 & 450 \\
\hline \multirow{2}{*}{ Janeiro } & 2002 & 320,2 & 19,3 & 24,5 & 29,8 & 4,7 & 410 \\
\hline & média 84 anos & 225,6 & 19,0 & 24,6 & 30,0 & 6,3 & 447 \\
\hline \multirow{2}{*}{ Fevereiro } & 2002 & 187,9 & 18,8 & 23,9 & 29,0 & 5,1 & 404 \\
\hline & média 84 anos & 184,1 & 19,0 & 24,6 & 30,2 & 6,5 & 438 \\
\hline
\end{tabular}

Fonte: USP/ESALQ, Departamento de Giências Exatas (2002).

Tabela 3. Balanço hídrico decendial durante o período experimental.

\begin{tabular}{|c|c|c|c|c|c|c|}
\hline \multicolumn{3}{|c|}{ Época } & \multirow{2}{*}{$\begin{array}{c}\text { Temperatura } \\
\text { ○C } \\
\end{array}$} & \multirow{2}{*}{ Precipitação } & \multirow{2}{*}{$\begin{array}{c}\text { Deficiência } \\
\text { mm }\end{array}$} & \multirow{2}{*}{ Excedente } \\
\hline Ano & Mês & Dias & & & & \\
\hline \multirow{3}{*}{2001} & & 1 a 10 & 22,1 & 111,2 & 0,0 & 41,7 \\
\hline & Outubro & 11 a 20 & 23,0 & 46,8 & 0,0 & 7,7 \\
\hline & & 21 a 31 & 23,2 & 15,3 & $-6,4$ & 0,0 \\
\hline \multirow{3}{*}{2001} & & 1 a 10 & 23,9 & 5,5 & $-20,2$ & 0,0 \\
\hline & Novembro & 11 a 20 & 24,2 & 98,0 & 0,0 & 22,3 \\
\hline & & 21 a 30 & 26,0 & 48,9 & 0,0 & 5,0 \\
\hline \multirow{3}{*}{2001} & & 1 a 10 & 23,8 & 32,8 & $-0,2$ & 0,0 \\
\hline & Dezembro & 11 a 20 & 24,9 & 64,2 & 0,0 & 20,0 \\
\hline & & 21 a 31 & 23,3 & 107,2 & 0,0 & 68,4 \\
\hline \multirow{3}{*}{2002} & & 1 a 10 & 24,8 & 117,0 & 0,0 & 79,1 \\
\hline & Janeiro & 11 a 20 & 22,6 & 74,8 & 0,0 & 42,3 \\
\hline & & 21 a 31 & 26,2 & 128,4 & 0,0 & 84,5 \\
\hline \multirow{3}{*}{2002} & & 1 a 10 & 23,3 & 133,3 & 0,0 & 100,1 \\
\hline & Fevereiro & 11 a 20 & 24,2 & 19,3 & $-2,2$ & 0,0 \\
\hline & & 21 a 28 & 24,4 & 35,3 & 0,0 & 0,0 \\
\hline
\end{tabular}

Fonte: USP/ESALQ, Departamento de Ciências Exatas (2002). 


\subsection{5 - Animais}

Com o objetivo de simular condições reais de pastejo por bovinos e promover a manutenção dos tratamentos experimentais (alturas de dossel forrageiro), foram utilizados bovinos de corte das raças Nelore e Canchim oriundos do plantel de animais puros (P.O.) do Departamento de Zootecnia da USP/ESALQ. Em virtude da reduzida área experimental, optou-se por animais jovens e relativamente leves. Foram selecionadas 30 novilhas desmamadas da raça Nelore, com média inicial de $206 \mathrm{~kg}$ de peso vivo, destinadas aos blocos I e III, e outras 30 novilhas desmamadas da raça Canchim, com média inicial de $234 \mathrm{~kg}$ de peso vivo, destinadas aos blocos II e IV. Os animais foram pareados em função do peso vivo e alocados (dois a dois) æ̀ unidades experimentais.

\section{2 - MÉTODOS}

\subsection{1 - Delineamento experimental e tratamentos}

O delineamento experimental adotado para condução do experimento foi o de blocos completos casualizados com quatro repetições. Os tratamentos corresponderam a quatro alturas do dossel forrageiro (10, 20, 30 e $40 \mathrm{~cm}$ ) mantidas constante ("steady state") através da adição ou retirada de animais das unidades experimentais. Portanto, durante todo o período experimental, adotou-se a técnica de lotação contínua com taxa de lotação variável. A área experimental possuía um total de 16 unidades experimentais com cerca de $1.200 \mathrm{~m}^{2}$ cada, perfazendo um total aproximado de 2 hectares (Figura 2). 


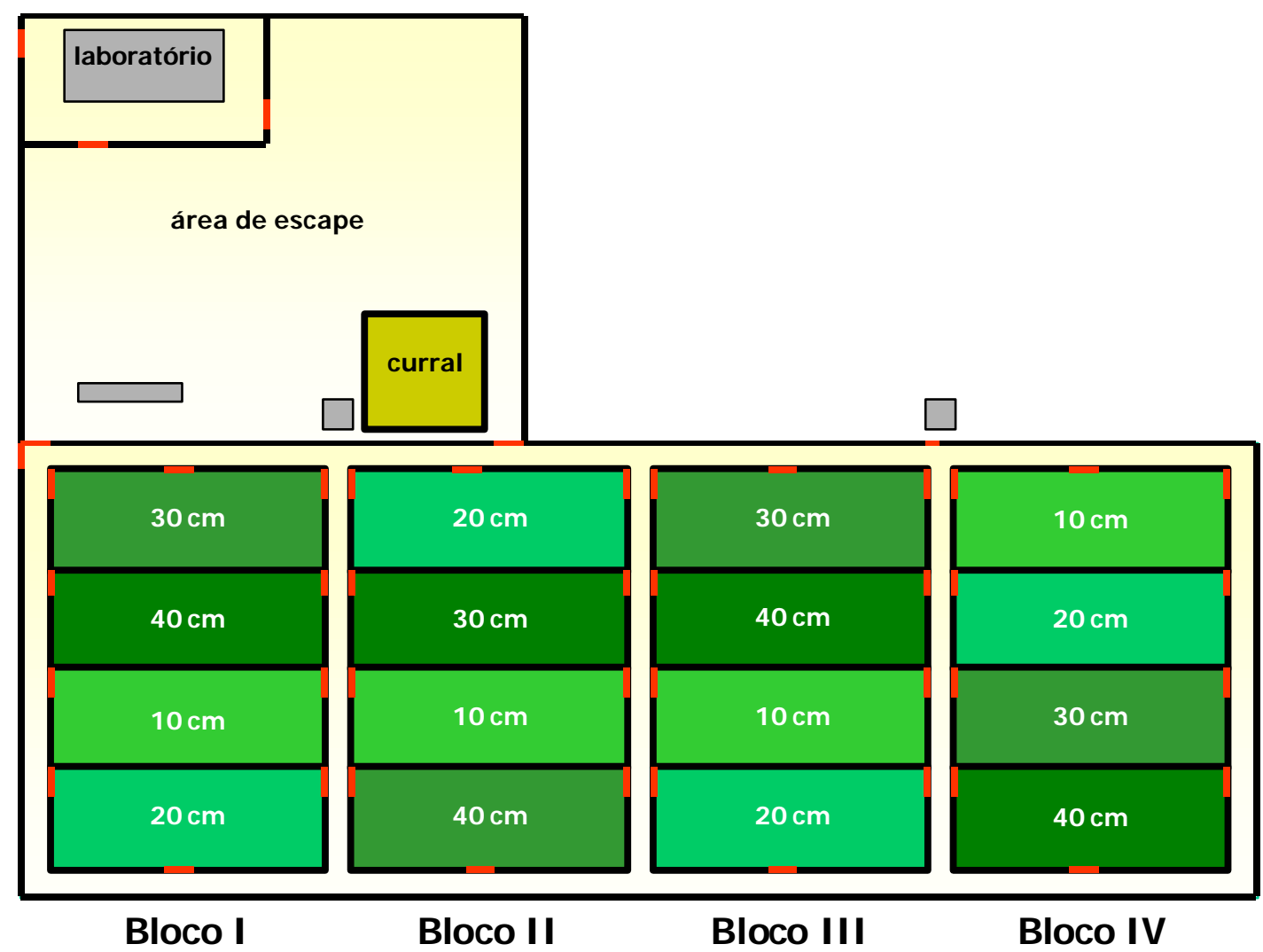

Figura 2 - Croqui da área experimental do GEPF.

\subsection{2 - Instalação das condições experimentais}

\subsubsection{1 - Semeadura}

A semeadura do capim Marandu teve início em 30 de setembro de 2000. Foram aplicados $7 \mathrm{~kg}$ de sementes puras viáveis por hectare através do uso de semeadoraadubadora de 4 linhas, com sistema de distribuição gravimétrico de fluxo contínuo, adaptada para o sistema de plantio direto. Devido ao grande número de falhas, foram necessárias intervenções e adotada a repicagem e plantio de mudas do mesmo capim em dezembro de 2000 , objetivando um maior fechamento da área.

Em janeiro de 2001 foram realizadas duas roçadas severas nos pastos a um curto intervalo de tempo (12 dias). Sua severidade e o período de deficiência hídrica 
moderada posterior a elas promoveu a morte de um grande número de touceiras, prejudicando o estabelecimento da pastagem. Tentou-se, a princípio, promover o restabelecimento apenas nos pontos mais prejudicados por semeadura a lanço no dia 11 de abril de 2001. No entanto, o efetivo estabelecimento da área só foi alcançado após a semeadura em área total, com $10 \mathrm{~kg}$ de sementes puras viáveis por hectare, através do uso de semeadora-adubadora de 20 linhas com sistema de distribuição gravimétrico de fluxo contínuo, específica para o sistema de plantio direto, no dia 21 de maio de 2001.

\subsubsection{2 - Controle de plantas daninhas}

A área experimental era formada anteriormente por pastagens de gênero Cynodon spp.. Para promover seu controle e permitir que a semeadura pudesse ser realizada, foram efetuadas aplicações de herbicida dessecante àbase de Glyphosate, na dosagem de $2,4 \mathrm{~kg}$ de ingrediente ativo (i.a.) por hectare.

Após a semeadura, as plantas invasoras que causaram os maiores problemas ao estabelecimento dos pastos foram os capins Tifton-85, Florakirk e Coastcross (Cynodon spp.), o capim pé-de-galinha (Eleusine indica L.), o capim rabo de raposa (Setaria geniculata (Lem.) Beauv.), o caruru (Amaranthus sp.), a beldroega (Portulaca oleraceae L.), e a corda-de-viola (Ipomoea sp.). O controle dessas plantas daninhas foi efetuado durante todo o período de estabelecimento das pastagens através da ação física pelo arranquio e capinas freqüentes, e pela ação química com o uso do herbicida Diclorofenoxiacético em área total, na dosagem de 2,4 kg de i.a. por hectare, ou de forma dirigida sobre as plantas invasoras através do uso de herbicida Glyphosate, na dosagem de 2,4 kg de i.a. por hectare. A partir de maio de 2001, a ação física de controle recebeu o reforço do pastejo seletivo efetuado por eqüinos e muares do Departamento de Zootecnia da USP/ESALQ, principalmente no combate a maior invasora, o Cynodon spp..

\subsubsection{3 - Fertilização e tratos culturais}

Dada a elevada fertilidade natural do solo da área experimental (Tabela 1), nenhum tipo de adubação de correção foi efetuada (item 3.1.3). Após a semeadura e 
estabelecimento, foram realizadas três adubações nitrogenadas antes do início do período de amostragens. A primeira foi realizada em 10 de janeiro de 2001, com a aplicação de uréia na dosagem correspondente a $67,5 \mathrm{~kg}$ por hectare de nitrogênio. A segunda foi realizada em 21 de janeiro de 2001, com a aplicação de sulfato de amônio em dosagem correspondente a $50 \mathrm{~kg}$ por hectare de nitrogênio, e a terceira, em 1 de outubro de 2001, com a aplicação de sulfato de amônio em dosagem correspondente a $50 \mathrm{~kg}$ por hectare de nitrogênio.

Imediatamente antes das adubações de janeiro de 2001, foram efetuadas roçadas com o objetivo de promover a elevação do número de touceiras na área pelo aumento do número de perfilhos. Nessa ocasião, as duas roçadas foram feitas o mais rente do solo possível, a cerca de 3 a 5 centímetros. Em março de 2001 uma nova roçada rente ao solo foi realizada. No final do mês de agosto de 2001 foi realizada uma roçada menos severa, com o intuito de uniformizar as pastagens em todas as parcelas (corte de uniformização). Essa roçada foi realizada a uma altura de 8 centímetros da superfície do solo, pouco abaixo da menor altura de tratamento $(10 \mathrm{~cm})$.

\subsection{3 - Monitoramento das condições experimentais}

\subsubsection{1 - Alturas dos tratamentos}

A partir da roçada de 28 e 29 de agosto, foi iniciado o monitoramento das condições de altura da pastagem nas parcelas experimentais. Esse controle era realizado através de medições a intervalos de 3 e 4 dias (2 vezes por semana), em 20 pontos em cada unidade experimental, com o uso de transparência e régua graduada em centímetros (FAGUNDES, 1999). Animais eram adicionados quando a altura do relvado apresentava-se acima do determinado para o tratamento, e retirados quando essa ficava abaixo do esperado. A princípio esperava-se uma tolerância da ordem de 10 a 15\%, mas, em determinados momentos, como ocorreu em janeiro de 2002, a necessidade de permanência dos animais por um maior período de tempo para que avaliações concomitantes de comportamento animal em experimento conjunto fossem realizadas causou decréscimo mais drástico da altura e massa de forragem dos tratamentos de 30 e 40 centímetros (Figura 3 e 4). 


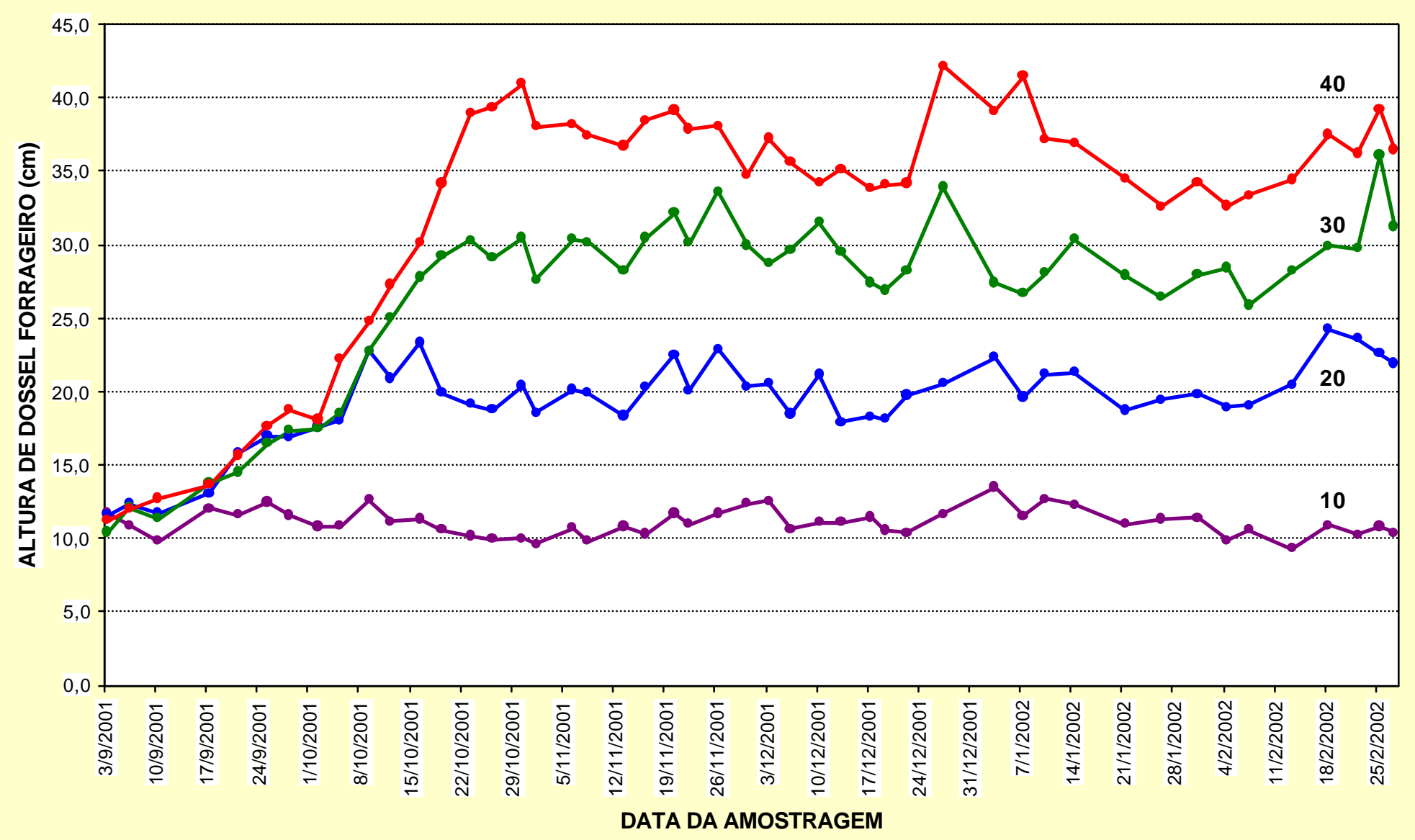

Figura 3 - Valores médios das alturas dos tratamentos $(\mathrm{cm})$ ao longo do período experimental. $10($ ), 20 ( ), 30 ( ) e 40 ( ). 


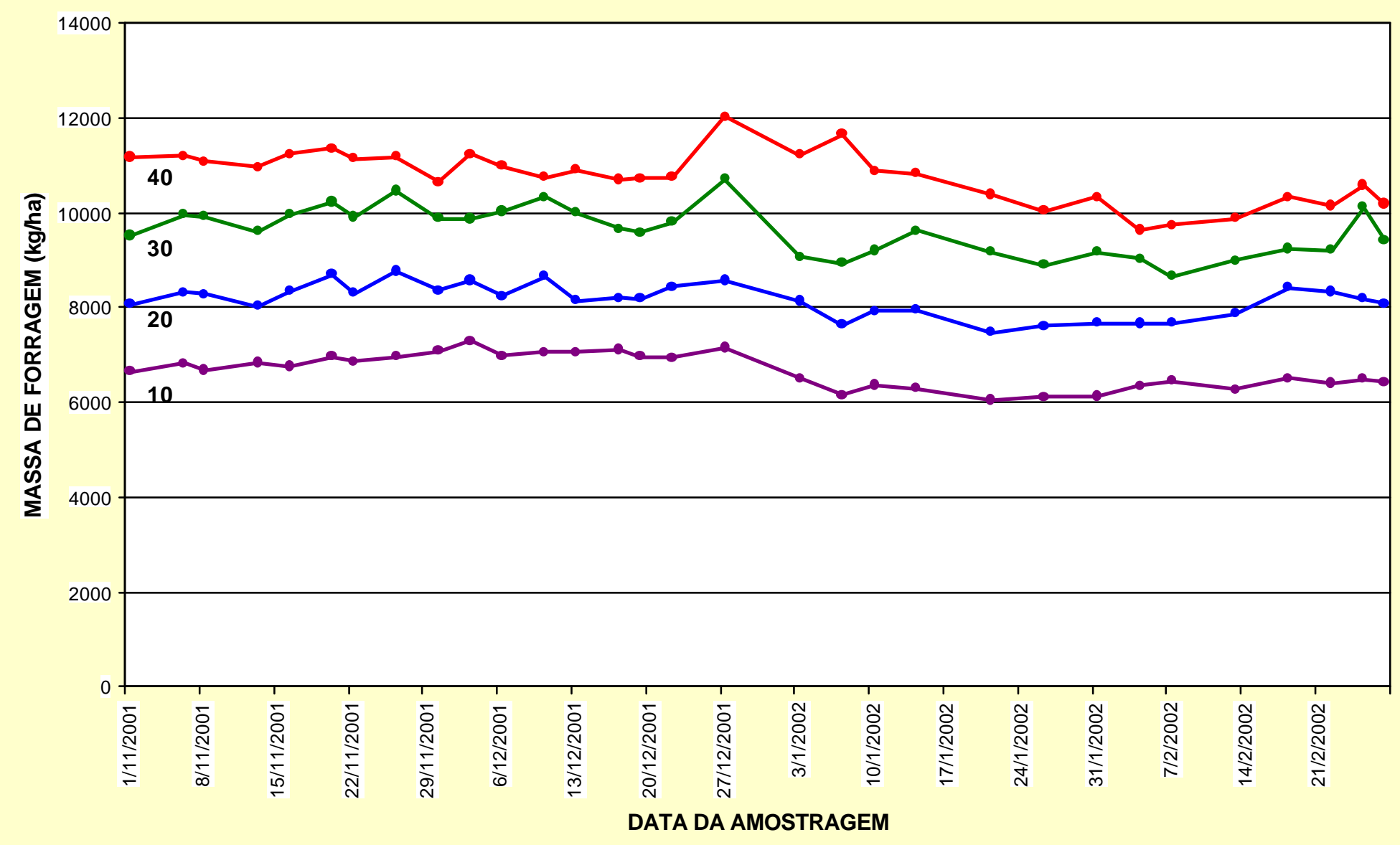

Figura 4 - Valores médios da massa de forragem ( $\mathrm{kg} / \mathrm{ha}$ ) ao longo do período experimental dos tratamentos (cm) $10($ ), 20( ), 30 ( ) e 40 ( ). 


\subsubsection{2 - Fertilização e tratos culturais}

Para assegurar a permanência dos animais pelo maior período de tempo possível nas parcelas experimentais através da produção e oferta abundantes de forragem, foram adotadas três adubações estratégicas com nitrogênio e potássio. $A$ primeira adubação ocorreu em 7 de novembro de 2001, com a aplicação de nitrato de amônio na dosagem correspondente a $20 \mathrm{~kg}$ por hectare de nitrogênio; em 1 de dezembro de 2001 foi efetuada a segunda adubação, com a aplicação da fórmula 30.00.20 na dosagem correspondente a $30 \mathrm{~kg}$ por hectare de nitrogênio e $20 \mathrm{~kg}$ por hectare de $\mathrm{K}_{2} \mathrm{O}$; e a terceira em 10 de janeiro de 2002, com a aplicação da fórmula 30.00.20 na dosagem correspondente a $45 \mathrm{~kg}$ por hectare de nitrogênio e $30 \mathrm{~kg}$ por hectare de $\mathrm{K}_{2} \mathrm{O}$.

\subsubsection{3 - Controle do peso vivo no período experimental}

Por ocasião do ajuste da taxa de lotação nas parcelas experimentais, tanto na entrada como na saída dos animais, era efetuada uma pesagem após jejum de alimento e água de 16 horas. Além da pesagem de ajuste de carga, todos os animais alocados para o experimento tiveram seus pesos em jejum coletados mensalmente para o acompanhamento do ganho de peso. A variação da média de pesos pode ser visualizada na Tabela 4.

Tabela 4. Peso vivo em jejum médio dos animais $(\mathrm{kg})$ utilizados para desfolha na manutenção dos tratamentos, durante o período experimental.

\begin{tabular}{cccccccc}
\hline & DATA & \multicolumn{2}{c}{ NELORE } & \multicolumn{2}{c}{ CANCHIM } & MÉDIA \\
Ano & Mês & Dia & Geral & “Testers" & Geral & “Testers” & GERAL \\
2001 & novembro & 20 & 205,3 & 231,6 & 237,2 & 257,5 & 221,2 \\
2001 & dezembro & 20 & 216,4 & 241,6 & 256,3 & 272,4 & 236,3 \\
2002 & janeiro & 27 & 232,2 & 259,7 & 269,7 & 286,3 & 250,9 \\
2002 & fevereiro & 19 & 244,8 & 272,6 & 278,4 & 292,6 & 261,6 \\
\hline
\end{tabular}




\subsection{4 - O período experimental}

O período experimental teve início em 01 de novembro de 2001, após a estabilização das alturas de pasto planejadas (Figura 3), e foi encerrado em 28 de fevereiro de 2002.

\subsection{5 - Avaliações de campo}

\subsubsection{1 - Seleção e demarcação de perfilhos}

Foram marcados diversos perfilhos do capim Marandu em todas as unidades experimentais e ao longo de todo o período de amostragem (GRANT \& MARRIOT, 1994). A marcação dos perfilhos deu-se pelo uso de barras de metal de 2 metros de comprimento, graduadas a cada 20 centímetros (BIRCHAM \& HODGSON, 1983; HU, 1993; WADE, 1991). Essas barras receberam a denominação de réguas transectas. As réguas foram colocadas em pontos da unidade experimental que fossem representativos da condição do relvado e apresentassem a altura média do tratamento, e sua posição foi demarcada com o uso de estacas coloridas para facilitar sua localização (Figura 5). Para cada régua foram selecionados 10 perfilhos, espaçados de 20 centímetros cada, e identificados por meio de anel plástico colorido (BIRCHAM \& HODGSON, 1983; HU, 1993; WADE, 1991). A cada ciclo de coleta de dados, de no mínimo 4 semanas, um novo grupo de perfilhos era selecionado para avaliação.

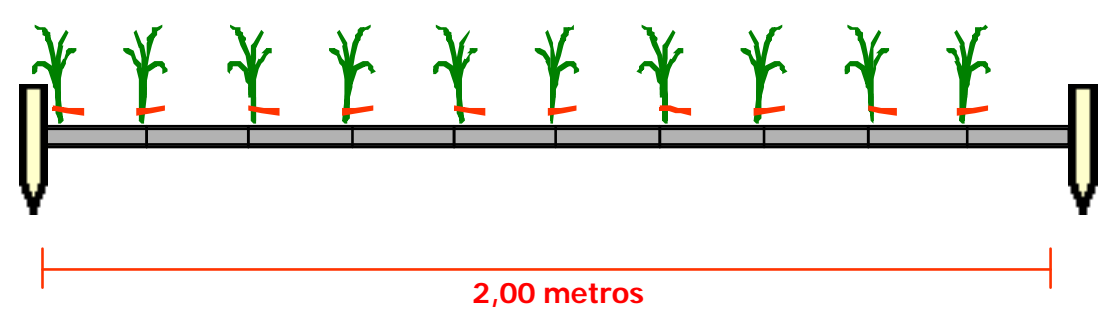

Figura 5 - Uso da régua transecta para demarcação de perfilhos individuais. 
Durante o mês de novembro de 2001, foram alocadas quatro réguas transectas por unidade experimental. O grande volume de dados gerados nesse primeiro mês de avaliação (160 perfilhos por tratamento) permitiu que o número de réguas por unidade experimental fosse reduzido para três a partir do mês de dezembro, ou seja, 120 perfilhos por tratamento, número este suficientemente grande para assegurar nível de precisão satisfatório para as avaliações sendo realizadas.

\subsubsection{2 - Avaliações de campo}

Em intervalos de tempo de 3 e 4 dias (2 avaliações por semana) foram anotadas diversas informações de cada um dos perfilhos selecionados (BIRCHAM \& HODGSON, 1983). Como conseqüência, foram obtidas 6, 8, 9 e 7 datas de coleta de dados para os meses de novembro de 2001, dezembro de 2001, janeiro de 2002 e fevereiro de 2002, respectivamente. Nessas ocasiões, os perfilhos passaram pelas seguintes avaliações: (a) medição de seu comprimento estendido (cm); (b) classificação como intacto ou desfolhado; (c) classificação como basal ou aéreo; e (d) contagem de seu número de folhas. Cada uma das folhas desses perfilhos também foi avaliada com relação às seguintes características: (a) comprimento do limbo foliar (cm); (b) classificada como intacta ou desfolhada; (c) classificada como folha em expansão, expandida, senescente e morta.

Para a medição do comprimento estendido de perfilhos, as últimas folhas eram colocadas eretas e mensurado o comprimento da ponta da folha mais alta até o nível do solo. Folhas e perfilhos eram considerados desfolhados quando parte deles estivesse cortado/decapitado. Folhas foram classificadas como em expansão quando suas lígulas não estavam expostas; expandidas quando a lígula estivesse visível e/ou seu crescimento cessasse (por vezes a lígula ficava internamente àbainha dificultando sua visualização); senescentes quando parte do limbo foliar apresentasse sinais de senescência; e mortas quando mais de $50 \%$ do limbo foliar estivesse comprometido pela senescência.

O comprimento das folhas foi medido de acordo com o estádio de desenvolvimento das mesmas. Para as folhas expandidas, mediu-se o comprimento da ponta da folha até sua lígula. No caso de folhas em expansão, o mesmo procedimento era adotado, porém, considerando a lígula da última folha expandida 
como referencial de medida. Para as folhas em senescência, ao invés da ponta da folha, considerou-se o ponto até onde o processo de senescência (amarelamento e enegrecimento) havia avançado (parte verde do limbo foliar).

\subsection{6 - Avaliações derivadas dos dados de campo}

Foram avaliados aspectos relativos à morfogênese das plantas (número de folhas vivas, em senescência e em expansão por perfilho; axa de aparecimento e longevidade de folhas) além da freqüência e intensidade de desfolhação de folhas e de perfilhos individuais.

\subsubsection{1 - Taxa de aparecimento de folhas}

A taxa de aparecimento de folhas (TAF) indica o número de folhas que aparece por perfilho por unidade de tempo ou unidade de somatória calórica, no caso, folhas por dia e folhas por graus-dia (GD), respectivamente. Ela foi obtida através da equação (1).

$\mathrm{TAF}=\mathrm{n}^{\circ}$ de novas folhas $/ \mathrm{n}^{\circ}$ de perfilhos $\mathrm{x}$ duração da avaliação (em dias ou GD)

No caso do cálculo em graus-dia, foi adotado como padrão a temperatura basal de $15^{\circ} \mathrm{C}$. Dessa forma, para cálculo dos valores de graus-dia dos períodos adotados para esta e outras variáveis, fez-se uso da equação (2).

Graus-dia = Ó (Temperatura média diária $\left.-15^{\circ} \mathrm{C}\right)$

\subsubsection{2 - Filocrono}

O filocrono é definido como o inverso da taxa de aparecimento de folhas (LEMAIRE \& CHAPMAN, 1996). Assim, os valores foram calculados com base na equação (3). 
Os valores resultantes foram expressos em dias/folha e graus-dia/folha.

\subsubsection{3 - Número de folhas vivas por perfilho}

Para obtenção do número de folhas vivas por perfilho (FVP) foi contabilizado o número médio de folhas em expansão, expandidas e em senescência de cada perfilho, ignorando as folhas onde o processo de senescência ultrapassou $50 \%$ do limbo foliar. O cálculo foi realizado através da equação (4).

FVP $=($ folhas em expansão + expandidas + senescentes $) / n^{0}$ perfilhos em avaliação

\subsubsection{4 - Longevidade das folhas}

O período de vida das folhas foi calculado em dias e em graus-dia, considerando-se o intervalo de tempo em dias e graus-dia decorrido desde seu aparecimento até sua morte, respectivamente. Sua obtenção derivou da equação (5).

LONGEVIDADE DAS FOLHAS = folhas vivas por perfilho $x$ filocrono (em dias e GD)

\subsubsection{5 - Freqüência de desfolhação}

Os resultados de freqüência de desfolhação podem ser obtidos de maneiras diversas, com resultados também variados. No presente experimento, o valor da freqüência de desfolhação foi obtido através da equação (6).

FREQÜÊNCIA $=n^{\circ}$ - de toques $/$ ( $n^{\circ}$ de possíveis toques $x$ duração da avaliação)

Todos os cálculos foram realizados para freqüência de desfolhação por folha, por tipo de folha (senescente, madura e em expansão), por perfilho, e por perfilho estendido. Dessa maneira, obteve-se o valor da freqüência de desfolhação em toques 
por dia, cujo inverso indica o intervalo de tempo compreendido entre duas desfolhas sucessivas.

\subsubsection{6 - Intensidade de desfolhação}

A intensidade de desfolhação foi obtida pela razão entre o comprimento consumido e o comprimento inicial, através da equação (7).

INTENSIDADE $=$ [(comprimento inicial - comprimento final) $/$ comprimento inicial $]$

Foram efetuados cálculos para intensidade de desfolhação por folha, por tipo de folha, e por perfilho estendido.

\subsubsection{7 - Eficiência de pastejo}

A eficiência de pastejo indica o quanto da forragem produzida foi efetivamente consumida pelos animais. Sua obtenção considera vários dos valores acima calculados, e advém da seqüência de cálculo demonstrada no exemplo abaixo:

\section{Dados para exemplo:}

freqüência de desfolhação $=0,05$

intensidade de desfolhação $=50 \%$

longevidade da folha $=30$ dias

1ํálculo: número de possíveis desfolhações (NPD), equação (8):

NPD = longevidade da folha $x$ freqüência de desfolhação

Exemplo:

$$
\mathrm{NPD}=30 \times 0,05=1,5
$$


2o cálculo: desmembrar NPD:

Separar o valor numérico de NPD em unidades e frações (soma de valores $\leq 1$ )

Exemplo:

$$
\mathrm{NPD}=1,5=1+0,5
$$

3o cálculo: redução no comprimento foliar:

Calcular a redução no comprimento foliar com base nas NPD desmembradas e na intensidade de desfolhação, de forma seqüencial (Figura 6).

Exemplo:

$$
\begin{aligned}
& \text { NPD }=1+0,5 \\
& \text { Intensidade }=50 \%
\end{aligned}
$$
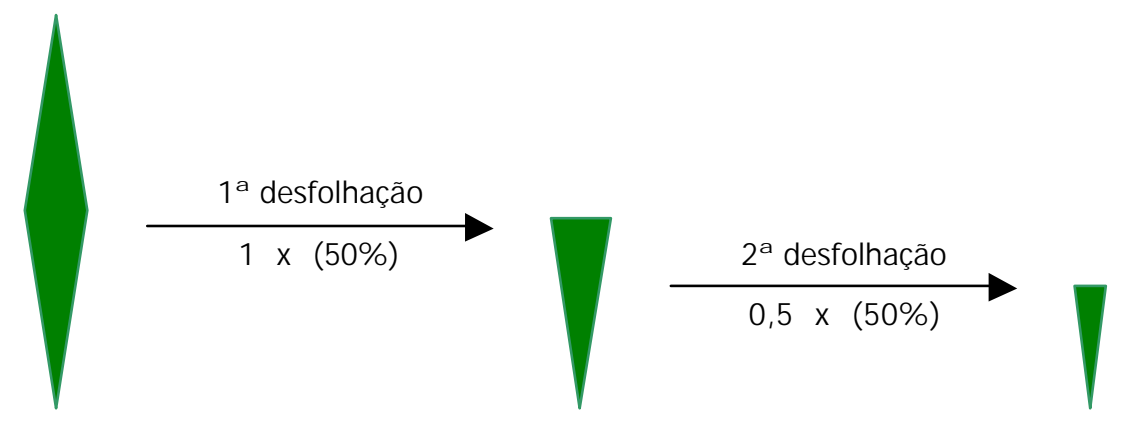

$100,0 \%$

$50,0 \%$ $37,5 \%$

Figura 6 - Redução no comprimento foliar por sucessão de desfolhações.

4o cálculo: eficiência de pastejo:

Proporção do comprimento inicial removida pelos animais através do pastejo:

Exemplo:

Eficiência $=100 \%-37,5 \%=62,5 \%$ 


\subsection{7 - Processamento dos dados}

\subsubsection{1 - Tabulação dos dados}

No campo, os dados referentes aos perfilhos e suas respectivas folhas eram anotados manualmente em planilhas impressas. Uma vez em laboratório, os mais de 400 mil dados foram todos transcritos para planilhas eletrônicas em arquivo Excell $\left(\right.$ Microsoft $\left.{ }^{\circledR}\right)$, desenvolvidas especificamente para essa finalidade.

\subsubsection{2 - Cálculo das médias}

Partindo das planilhas eletrônicas, foram desenvolvidas fórmulas ainda dentro do programa Excell $\left(\right.$ Microsoft $^{\circledR}$ ) que permitiram o cálculo das variáveis estudadas e de suas médias (item 3.2.6).

\subsection{8 - Análise estatística}

A análise estatística dos dados foi obtida por intermédio do pacote estatístico SAS (Statistical Analysis System), versão 8.0 para Windows, utilizando-se o PROC MIXED para a análise de variância, uma vez que foram realizadas medidas repetidas no tempo (SAS INSTITUTE, 2002). A comparação das médias foi feita através do "LSMEANS" com um nível de significância de 10\%. Foi realizado um estudo da relação funcional entre a freqüência de desfolhação de perfilhos e a capacidade de suporte das pastagens através do PROC REG do mesmo pacote estatístico. 


\section{$4 \quad$ RESULTADOS E DISCUSSÃO}

\section{1 - CARACTERÍSTICAS MORFOGÊNICAS}

\subsection{1 - Taxa de aparecimento de folhas}

\subsubsection{1 - Expressa em no de folhas/perfilho.dia}

A taxa de aparecimento de folhas (TAF) medida em folhas/perfilho.dia sofreu influência de altura do dossel forrageiro $(P=0,0414)$, mês do ano $(P=0,0003)$ e efeito da interação altura:mês $(P=0,0286)$, conforme observado na Tabela 5 e Figura 7.

Tabela 5. Taxa de aparecimento de folhas (folhas/perfilho.dia) em pastos de capim Marandu mantidos em quatro alturas de dossel forrageiro, de novembro de 2001 a fevereiro de 2002.

\begin{tabular}{|c|c|c|c|c|c|c|}
\hline \multirow{2}{*}{ MÊS } & \multicolumn{4}{|c|}{$\operatorname{ALTURA}(\mathrm{cm})$} & \multirow{2}{*}{ MÉDIA } & \multirow{2}{*}{ EPM $^{*}$} \\
\hline & 10 & 20 & 30 & 40 & & \\
\hline Novembro & $0,16^{\mathrm{aA}}$ & $0,14^{\mathrm{abA}}$ & $0,12^{\mathrm{bA}}$ & $0,12^{\mathrm{bA}}$ & $0,14^{\mathrm{A}}$ & 0,006 \\
\hline Dezembro & $0,10^{\mathrm{aBC}}$ & $0,11^{\mathrm{aB}}$ & $0,10^{\mathrm{aA}}$ & $0,11^{\mathrm{aA}}$ & $0,10^{\mathrm{B}}$ & 0,004 \\
\hline Janeiro & $0,12^{\mathrm{aB}}$ & $0,09^{b B C}$ & $0,10^{\mathrm{abA}}$ & $0,09^{\mathrm{bB}}$ & $0,10^{\mathrm{B}}$ & 0,004 \\
\hline Fevereiro & $0,09^{\mathrm{aC}}$ & $0,08^{\mathrm{abC}}$ & $0,08^{\mathrm{abB}}$ & $0,07^{\mathrm{bC}}$ & $0,08^{C}$ & 0,003 \\
\hline MÉDIA & $0,12^{\mathrm{a}}$ & $0,11^{b}$ & $0,10^{b}$ & $0,10^{b}$ & & \\
\hline EPM $^{*}$ & 0,005 & 0,004 & 0,004 & 0,005 & & \\
\hline
\end{tabular}

Médias na linha seguidas de mesmas letras minúsculas não diferem entre si (P>0,10)

Médias na coluna seguidas de mesmas letras maiúsculas não diferem entre si $(\mathbf{P} \geq 0,10)$ 


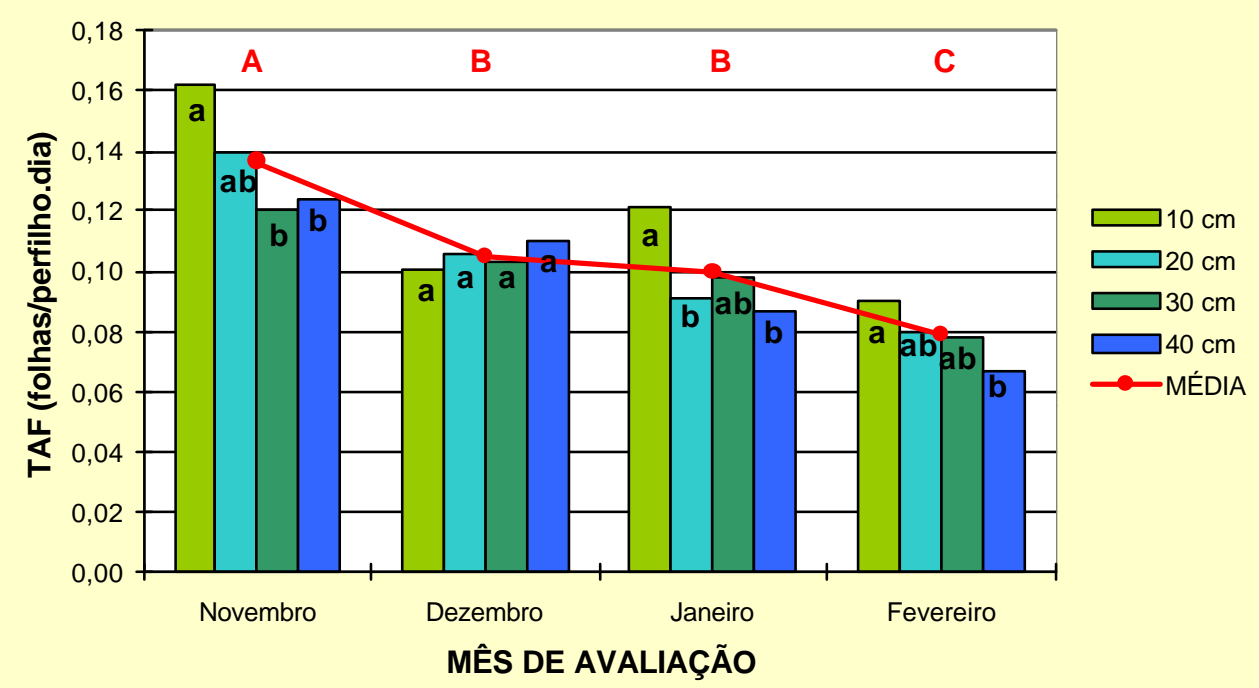

Figura 7 - Taxa de aparecimento de folhas (folhas/perfilho.dia) em pastos de capim Marandu mantidos em quatro alturas de dossel forrageiro, de novembro de 2001 a fevereiro de 2002

Os valores encontrados revelaram uma TAF variando de 0,07 folha/perfilho.dia (altura de $40 \mathrm{~cm}$ em fevereiro de 2002) a 0,16 folha/perfilho.dia (altura de $10 \mathrm{~cm}$ em novembro de 2001), amplitude de valores superior àquela encontrada por CORSI et al. (1994) que, trabalhando com a mesma planta forrageira, chegaram a valores variando entre 0,15 a 0,19 folha/perfilho.dia. Plantas do mesmo gênero, como a braquiária decumbens (Brachiaria decumbens Stapf.), demonstraram valores de TAF bastante próximos, oscilando de 0,10 a 0,18 folha/perfilho.dia (CORSI et al., 1994; GOMIDE et al., 1997; GOMIDE et al., 1998).

Durante todos os meses avaliados, houve efeito da altura de dossel forrageiro sobre a TAF $(P=0,0414)$. Pastos mantidos a 20, 30 e $40 \mathrm{~cm}$ apresentaram menores valores de TAF que pastos mantidos a $10 \mathrm{~cm}$, exceção feita ao mês de dezembro de 2001, onde não foi constatada diferença entre as alturas estudadas.

Os dados encontrados por CAVALCANTE et al. (2002b) em estudo com braquiária decumbens sob diferentes alturas de dossel forrageiro (10, 15, 20 e $25 \mathrm{~cm}$ ) também indicaram que àmedida que o pasto era mantido mais alto, a TAF diminuía, variando de 0,107 folha/perfilho.dia para a altura de $10 \mathrm{~cm}$ até 0,079 folha/perfilho.dia 
para a altura de $25 \mathrm{~cm}$. Resultados semelhantes foram encontrados para plantas de clima temperado por PARSONS et al. (1991b), que constataram que a TAF do azevém perene variou conforme a altura do relvado de 0,09 a 0,13 folha/pefilho.dia para pastos mantidos a 9 e $3 \mathrm{~cm}$, respectivamente. Uma das razões para essa mudança na TAF seria a maior distância a ser percorrida pela folha no interior da pseudo-haste de pastos mantidos mais altos (perfilhos maiores) até que pudesse ser vista e, consequentemente, contabilizada (CARVALHO \& DAMASCENO, 1996; GOMIDE, 1997; SKINNER \& NELSON, 1995).

Efeitos de ambiente podem influir na TAF, em especial a luz, temperatura, disponibilidade de água e nutrientes (NABINGER, 1997). Contudo, os efeitos da altura do dossel forrageiro sobre a TAF podem estar relacionados ao sombreamento provocado por folhas e outras estruturas da porção superior do dossel, inibindo a atividade de gemas e comprometendo a formação de novas folhas e novos perfilhos (FRANK \& HOFMAN, 1994). OLIVEIRA et al. (1998), trabalhando com o capim Tifton85, também observaram que os valores de TAF decresciam com o aumento da altura do dossel forrageiro.

O mês de avaliação também exerceu forte influência sobre a TAF $(P=0,0003)$, com o maior valor registrado no mês de novembro de 2001, o menor valor no mês de fevereiro de 2002, enquanto que para os meses de dezembro de 2001 e janeiro de 2002 não houve diferença $(P \geq 0,10)$ e os valores foram intermediários àqueles de novembro de 2001 e fevereiro de 2002. Efeitos relacionados a mês do ano sobre a TAF em plantas forrageiras de clima tropical já foram descritos por diversos autores (BARBOSA et al., 1996; CORSI et al., 1994; PACIULLO et al., 2002), tendo sido mencionado que além do efeito de fatores de ambiente, em especial da temperatura do ar e luminosidade, também exerce influência marcante 0 estádio de desenvolvimento das plantas (vegetativo $x$ reprodutivo), com redução dos valores de TAF à medida que as plantas iniciam a emissão de inflorescências. No presente trabalho, o processo de florescimento foi iniciado em dezembro de 2001, com os pastos atingindo florescimento pleno durante os meses de janeiro e fevereiro de 2002 (Figura 8), o que explicaria os valores decrescentes de TAF ao longo do período experimental. 


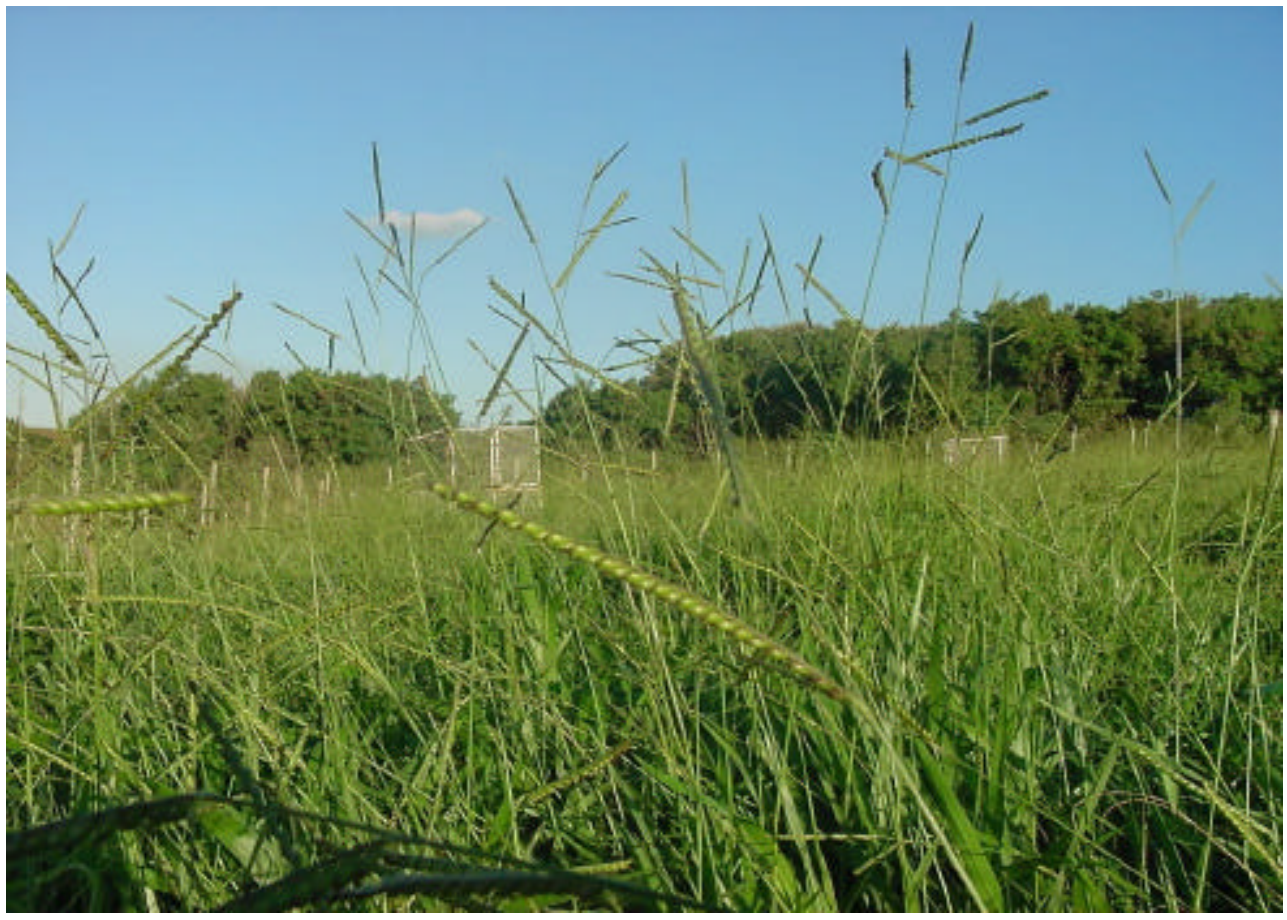

Figura 8 - Fotografia da área experimental ilustrando o intenso florescimento do capim Marandu durante o mês de fevereiro de 2002.

\subsubsection{2 - Expressa em no de folhas/perfilho.graus-dia}

A taxa de aparecimento de folhas expressa em folhas/perfilho.graus-dia (TAFGD) sofreu influência de altura do dossel forrageiro $(P=0,0012)$ e mês do ano $(P<$ $0,0001)$, não tendo sido constatado efeito da interação altura:mês $(P=0,5167)$. Os resultados encontrados são apresentados na Tabela 6.

Foram apurados valores de 0,007 a 0,015 folha/perfilho.graus-dia para a altura de dossel forrageiro de $40 \mathrm{~cm}$ em fevereiro de 2002 e $10 \mathrm{~cm}$ em novembro de 2001, respectivamente. Há escassez de dados sobre TAF-GD para plantas tropicais, entretanto, trabalhando os dados levantados por PINTO (2000), é possível determinar valores de TAF-GD para gramíneas do gênero Cynodon spp. oscilando de 0,015 a 0,034 folha/perfilho.graus-dia, revelando certa similaridade nos valores obtidos apesar de tratar-se de plantas forrageiras de espécies diferentes. 
Tabela 6. Taxa de aparecimento de folhas (folhas/perfilho.graus-dia) em pastos de capim Marandu mantidos em quatro alturas de dossel forrageiro, de novembro de 2001 a fevereiro de 2002.

\begin{tabular}{|c|c|c|c|c|c|c|}
\hline \multirow{2}{*}{ MÊS } & \multicolumn{4}{|c|}{ ALTURA (cm) } & \multirow{2}{*}{ MÉDIA } & \multirow{2}{*}{$\mathrm{EPM}^{*}$} \\
\hline & 10 & 20 & 30 & 40 & & \\
\hline Novembro & 0,015 & 0,013 & 0,012 & 0,012 & $0,013^{A}$ & 0,0003 \\
\hline Dezembro & 0,014 & 0,012 & 0,012 & 0,012 & $0,012^{A}$ & 0,0003 \\
\hline Janeiro & 0,010 & 0,010 & 0,010 & 0,009 & $0,010^{\mathrm{B}}$ & 0,0003 \\
\hline Fevereiro & 0,010 & 0,009 & 0,009 & 0,007 & $0,009^{C}$ & 0,0003 \\
\hline MÉDIA & $0,012^{\mathrm{a}}$ & $0,011^{b}$ & $0,011^{b c}$ & $0,010^{c}$ & & \\
\hline EPM $^{*}$ & 0,0003 & 0,0002 & 0,0002 & 0,0002 & & \\
\hline
\end{tabular}

EPM - Erro padrão da média

Médias na linha seguidas de mesmas letras minúsculas não diferem entre si $(P>0,10)$

Médias na coluna seguidas de mesmas letras maiúsculas não diferem entre si $(\mathbb{B} \geq 0,10)$

Foi verificado efeito de altura do dossel forrageiro sobre a TAF-GD $(P=0,0012)$. O pasto mantido a $10 \mathrm{~cm}$ apresentou o maior valor, aqueles mantidos a 20 e $30 \mathrm{~cm}$ valores intermediários semelhantes, e o mantido a $40 \mathrm{~cm}$ apresentou o menor valor, embora não diferente da altura de $30 \mathrm{~cm}$ (Figura 9). Tal comportamento é semelhante àquele descrito para TAF, ou seja, menores alturas de dossel forrageiro propiciaram melhor ambiente luminoso induzindo uma maior TAF-GD. Além disso, há o efeito da maior distância a ser percorrida pela folha em perfilhos maiores existentes nos pastos mantidos mais altos, o que contribuiu para a diminuição da TAF-GD. 


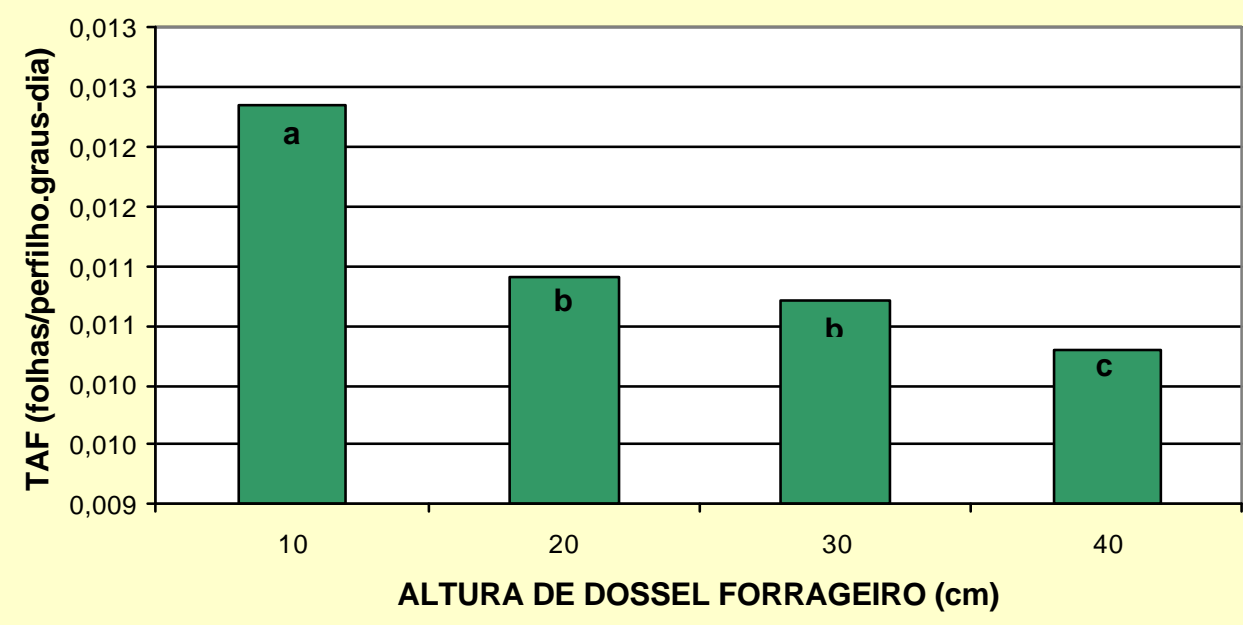

Figura 9 - Taxa de aparecimento de folhas (folhas/perfilho.graus-dia) em pastos de capim Marandu mantidos em quatro alturas de dossel forrageiro.

O mês de avaliação também exerceu efeito sobre a TAF-GD $(P<0,0001)$, tendo sido encontrados valores maiores para os meses de novembro e dezembro de 2001, valores intermediários em janeiro de 2002, e valores inferiores em fevereiro de 2002 (Figura 10). A TAF-GD mostrou comportamento similar àTAF, indicando que o efeito provocado pelo início da fase reprodutiva da planta forrageira também promoveu a redução nos valores de TAF-GD. SKINNER \& NELSON (1994) associaram esse fato ao efeito da fase reprodutiva sobre características morfológicas da planta forrageira, segundo o qual a partir da emissão da inflorescência cessa a emissão de folhas do perfilho, contribuindo para a redução da TAF do pasto. Nessa mesma fase fisiológica ocorre a elevação do meristema apical, tornando mais suscetível sua remoção através do pastejo direto pelos animais. Nessas condições, ao ser removido o meristema apical, nenhuma nova folha surge no perfilho desfolhado. Esses resultados foram corroborados por VAN ESBROECK et al. (1997) em estudo com Panicum virgatum, onde os autores verificaram uma redução nos valores de TAF-GD associada à transição do estádio de desenvolvimento vegetativo para o reprodutivo. 


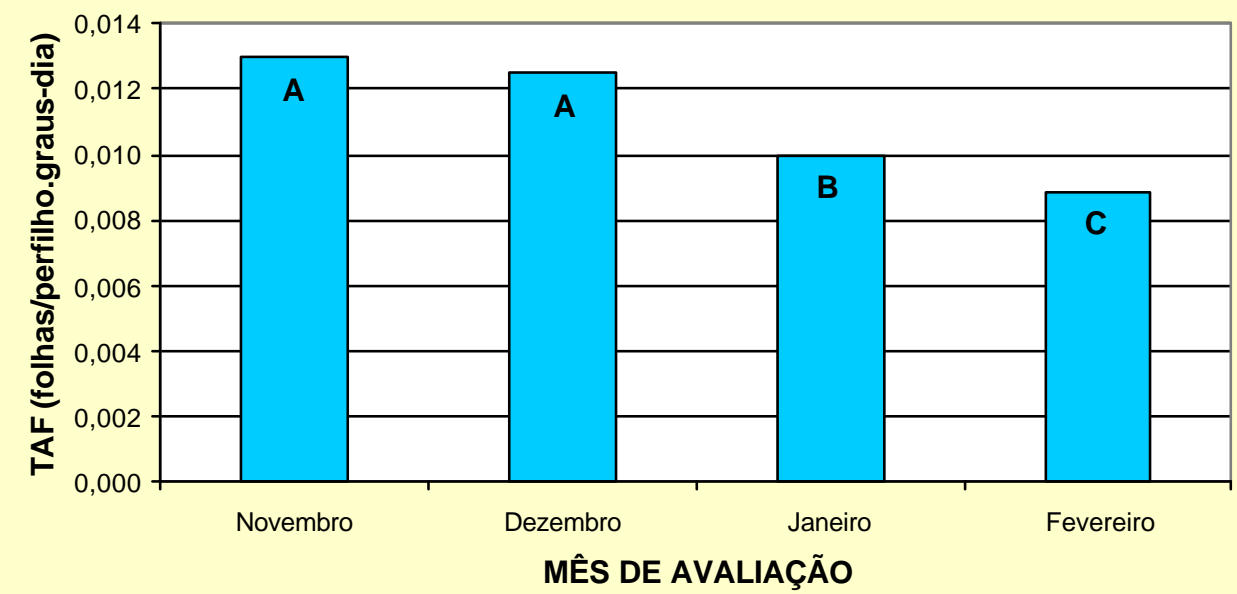

Figura 10 - Taxa de aparecimento de folhas (folhas/perfilho.graus-dia) em pastos de capim Marandu de novembro de 2001 a fevereiro de 2002.

\subsection{2 - Filocrono}

\subsubsection{1 - Expresso em dias/folha}

O filocrono do capim Marandu foi influenciado pelo mês do ano $(P=0,0003)$ e pela interação altura:mês $(P=0,0256)$, como pode ser constatado na Tabela 7 e na Figura 9. Não houve efeito de altura do dossel $(P=0,4444)$ (Tabela 7).

Os valores encontrados variaram de 6,2 a 15,8 dias/folha para a altura de dossel forrageiro de $10 \mathrm{~cm}$ em novembro de 2001 e $40 \mathrm{~cm}$ em fevereiro de 2002, respectivamente. Esses valores, embora próximos, são superiores àqueles obtidos por CORSI et al. (1994) para a mesma planta forrageira, que variaram de 5,3 a 6,7 dias/folha. Os mesmos autores em estudos com outras plantas do mesmo gênero encontraram valores de filocrono próximos aos obtidos para o capim Marandu em seu trabalho, ficando a braquiária decumbens numa faixa de 5,5 a 6,9 dias/folha e a braquiária humidícola (Brachiaria humidicola Rendle) de 4,0 a 6,3 dias/folha. Já GOMIDE et al. (1997) relataram um filocrono de 7,1 a 10 dias/folha para a braquiária decumbens. Essa variabilidade dos resultados pode ser explicada pela grande influência que fatores de ambiente exercem diretamente sobre o filocrono (SANTOS, 
1997), além dos regimes de desfolhação específicos impostos às plantas na forma de tratamentos experimentais.

Tabela 7. Filocrono (dias/folha) em pastos de capim Marandu mantidos em quatro alturas de dossel forrageiro, de novembro de 2001 a fevereiro de 2002.

\begin{tabular}{|c|c|c|c|c|c|c|}
\hline \multirow{2}{*}{ MÊS } & \multicolumn{4}{|c|}{ ALTURA (cm) } & \multirow{2}{*}{ MÉDIA } & \multirow{2}{*}{$\mathrm{EPM}^{*}$} \\
\hline & 10 & 20 & 30 & 40 & & \\
\hline Novembro & $6,2^{\mathrm{bB}}$ & $7,3^{\mathrm{abB}}$ & $8,3^{\mathrm{aB}}$ & $7,8^{\mathrm{abD}}$ & $7,4^{\mathrm{C}}$ & 0,37 \\
\hline Dezembro & $10,0^{\mathrm{aA}}$ & $9,7^{\mathrm{AA}}$ & $9,9^{\mathrm{aA}}$ & $8,8^{\mathrm{aC}}$ & $9,6^{\mathrm{B}}$ & 0,46 \\
\hline Janeiro & $9,2^{\mathrm{aAB}}$ & $11,4^{\mathrm{aA}}$ & $10,2^{\mathrm{aAB}}$ & $11,2^{\mathrm{aB}}$ & $10,5^{\mathrm{B}}$ & 0,72 \\
\hline Fevereiro & $10,8^{\mathrm{bA}}$ & $12,6^{\mathrm{abA}}$ & $12,9^{\mathrm{abA}}$ & $15,8^{\mathrm{aA}}$ & $13,0^{A}$ & 0,77 \\
\hline MÉDIA & 9,0 & 10,3 & 10,3 & 10,9 & & \\
\hline EPM $^{*}$ & 0,82 & 0,76 & 0,76 & 0,74 & & \\
\hline
\end{tabular}

Não ocorreu efeito de altura do dossel forrageiro sobre o filocrono $(P=0,4444)$. Entretanto, avaliando o efeito da interação altura:mês $(P=0,0256)$, constata-se que nos meses de novembro de 2001 e fevereiro de 2002 ocorreu diferença $(P<0,10)$ entre as alturas estudadas, ficando as alturas de 20,30 e $40 \mathrm{~cm}$ com os maiores valores, mas sem diferença entre a de $10 \mathrm{~cm}$ e as de 20 e $40 \mathrm{~cm}$ em novembro de 2001, e entre a altura de $10 \mathrm{~cm}$ e as de 20 e $30 \mathrm{~cm}$ em fevereiro de 2002. Nos meses de dezembro de 2001 e janeiro de 2002 não houve diferença alguma entre as alturas de pasto estudadas (Figura 11).

O mês do ano exerceu influência marcante sobre o filocrono $(P=0,0003)$, demonstrando variações da ordem de até $75 \%$ (7,4 a 13,0 dias/folha). O menor valor foi verificado em novembro de 2001 (7,4 dias/folha), o maior em fevereiro de 2002 (13,0 dias/folha), sendo aqueles referentes a dezembro de 2001 e janeiro de 2002 intermediários (9,6 e 10,5 dias/folha, respectivamente). Essa variação nos valores de filocrono ao longo do ano está geralmente associada ao efeito de fatores de ambiente. 
Entretanto, durante o período experimental, fatores como temperatura do ar e insolação apresentaram variações reduzidas (Tabelas 2 e 3), ao mesmo tempo que o balanço hídrico revelou não ter havido déficit severo durante o mesmo período (Tabela 3 ), indicando não terem sido esses fatores os causadores das variações em filocrono.

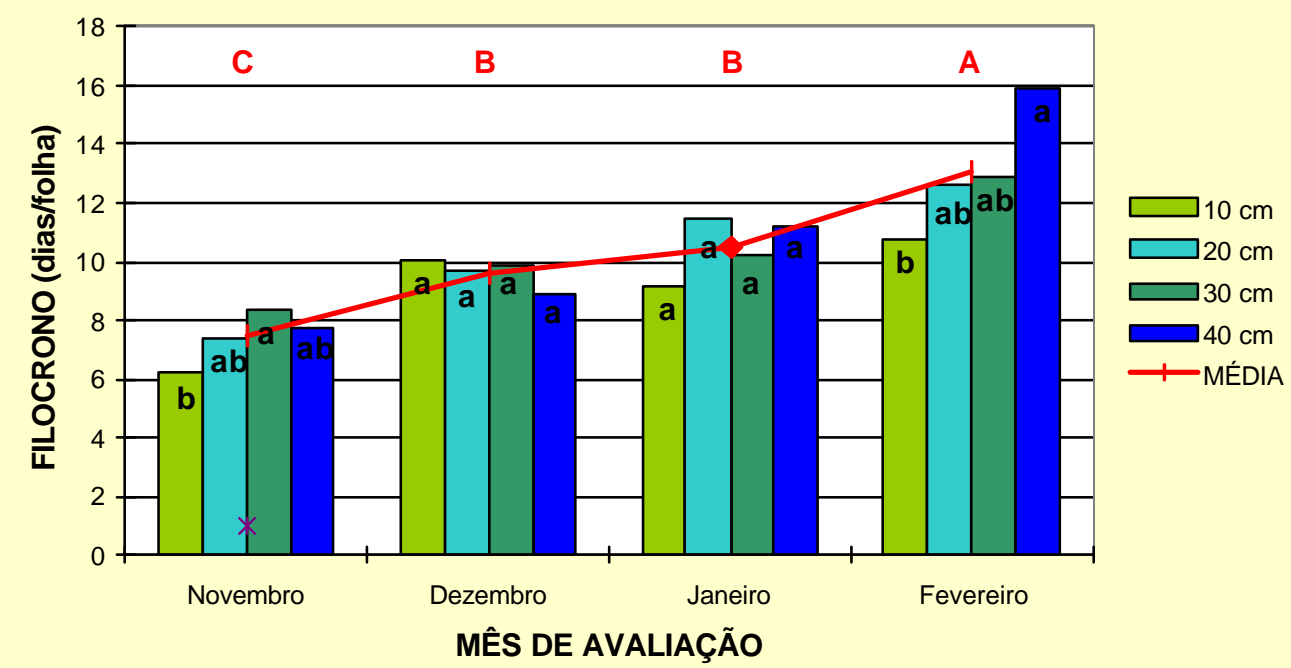

Figura 11 - Filocrono (dias/folha) em pastos de capim Marandu mantidos em quatro alturas de dossel forrageiro, de novembro de 2001 a fevereiro de 2002.

Considerando que os valores de filocrono foram calculados como o inverso da TAF, as mesmas justificativas apresentadas são validas para o filocrono. Portanto, a razão das variações no filocrono, a exemplo daquelas demonstradas para TAF e TAF$\mathrm{GD}$, são derivadas do avanço no estádio de desenvolvimento reprodutivo da planta forrageira. Esse fato foi corroborado por VAN ESBROECK et al. (1997) que, em estudo com Panicum virgatum, verificaram haver relação direta entre filocrono e florescimento, ou seja, à medida que a planta forrageira inicia a fase reprodutiva os valores de filocrono tornam-se maiores. Neste trabalho, a indução ao florescimento começou em dezembro de 2001, onde o filocrono foi de 7,4 dias/folha, tendo seu ápice em fevereiro de 2002, quando o filocrono chegou a 13 dias/folha. 


\subsubsection{1 - Expresso em graus-dia/folha}

Sobre o filocrono medido em graus-dias/folha (F-GD), ocorreram efeitos de altura do dossel forrageiro $(P=0,0373)$ e de mês do ano $(P<0,0001)$. Porém, a interação entre essas duas variáveis não ocorreu $(P=0,5987)$, como pode ser visualizado na Tabela 8. Os valores encontrados variaram de 65,6 a 128,5 grausdia/folha para altura de pasto de $10 \mathrm{~cm}$ em novembro de 2001 e $40 \mathrm{~cm}$ em fevereiro de 2002, respectivamente. A grande escassez de informações sobre F-GD para plantas forrageiras tropicais acaba limitando comparações de resultados. PINTO (2000) encontrou valores para Cynodon spp. relativamente próximos aos aqui apresentados, em época similar do ano, os quais oscilaram de 44,2 a 61,1 graus-dia/folha.

Tabela 8. Filocrono (graus-dia/folha) em pastos de capim Marandu mantidos em quatro alturas de dossel forrageiro, de novembro de 2001 a fevereiro de 2002.

\begin{tabular}{|c|c|c|c|c|c|c|}
\hline \multirow{2}{*}{ MÊS } & \multicolumn{4}{|c|}{ ALTURA $(\mathrm{cm})$} & \multirow{2}{*}{ MÉDIA } & \multirow{2}{*}{$\mathrm{EPM}^{*}$} \\
\hline & 10 & 20 & 30 & 40 & & \\
\hline Novembro & 65,6 & 78,0 & 83,7 & 85,1 & $78,1^{\mathrm{C}}$ & 1,89 \\
\hline Dezembro & 73,4 & 84,0 & 86,4 & 80,6 & $81,1^{\mathrm{C}}$ & 3,74 \\
\hline Janeiro & 99,7 & 105,2 & 98,5 & 108,3 & $102,9^{\mathrm{B}}$ & 3,60 \\
\hline Fevereiro & 100,6 & 113,1 & 111,7 & 128,5 & $113,5^{\mathrm{A}}$ & 2,39 \\
\hline MÉDIA & $84,8^{b}$ & $95,1^{a}$ & $95,1^{a}$ & $100,6^{a}$ & & \\
\hline EPM $^{*}$ & 3,20 & 3,07 & 3,07 & 3,08 & & \\
\hline
\end{tabular}

Os resultados apurados indicam ter havido efeito negativo da altura do dossel forrageiro sobre o F-GD, tendo sido encontrado o menor valor nos pastos mantidos a $10 \mathrm{~cm}$, enquanto os mantidos nas demais alturas $(20,30$ e $40 \mathrm{~cm})$ não apresentaram diferenças $(P \geq 0,10)$ entre eles (Figura 12). O principal responsável pela variação no F-GD parece ser a penetração de luz ao longo do dossel forrageiro e sua influência 
sobre o ambiente luminoso no interior do dossel, induzindo o aparecimento de folhas a intervalos de tempo menores quanto maior a luz incidente (FRANF \& HOFMAN, 1994). Nesse contexto, pastos mantidos a $10 \mathrm{~cm}$ permitiram uma maior disponibilidade e qualidade de luz no interior do dossel forrageiro em relação àqueles mantidos em alturas mais elevadas $(20,30 \text { e } 40 \mathrm{~cm})^{1}$.

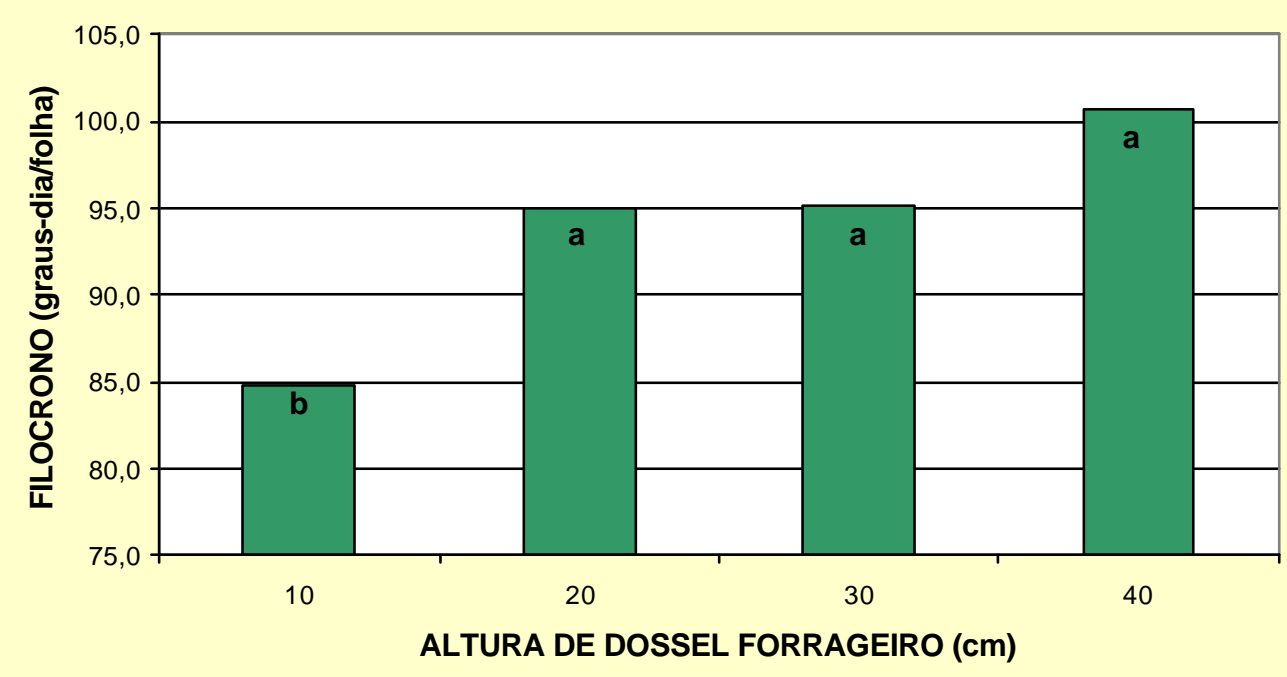

Figura 12 - Filocrono (graus-dia/folha) em pastos de capim Marandu mantidos em quatro alturas de dossel forrageiro, de novembro de 2001 a fevereiro de 2002.

A época do ano exerceu influência sobre o $F G D(P<0,0001)$, variando os valores positivamente com o avanço do período experimental. Durante os meses de novembro e dezembro de 2001 não houve alteração significativa dos valores. Entretanto, a partir de janeiro de 2002 ocorreu elevação, culminando no maior valor de F-GD na avaliação de fevereiro de 2002 (Figura 13). Da mesma forma que fôra constatado para filocrono (dias/folha), as oscilações de F-GD em relação ao mês do ano foram derivadas do estádio de desenvolvimento reprodutivo da planta forrageira,

\footnotetext{
${ }^{1}$ MOLAN, L. K. (Escola Superior de Agricultura “Luiz de Queiroz", Piracicaba, SP). Estrutura do dossel e interceptação luminosa em pastos de Brachiaria brizantha cv. Marandu (projeto de mestrado em andamento).
} 
que surgiu durante o período experimental. À medida que o processo de florescimento foi instalado, os valores de F-GD aumentaram até o pico em fevereiro de 2002, mês de maior ocorrência de inflorescências nos pastos, especialmente naqueles mantidos a 30 e $40 \mathrm{~cm}$ (Figura 8).

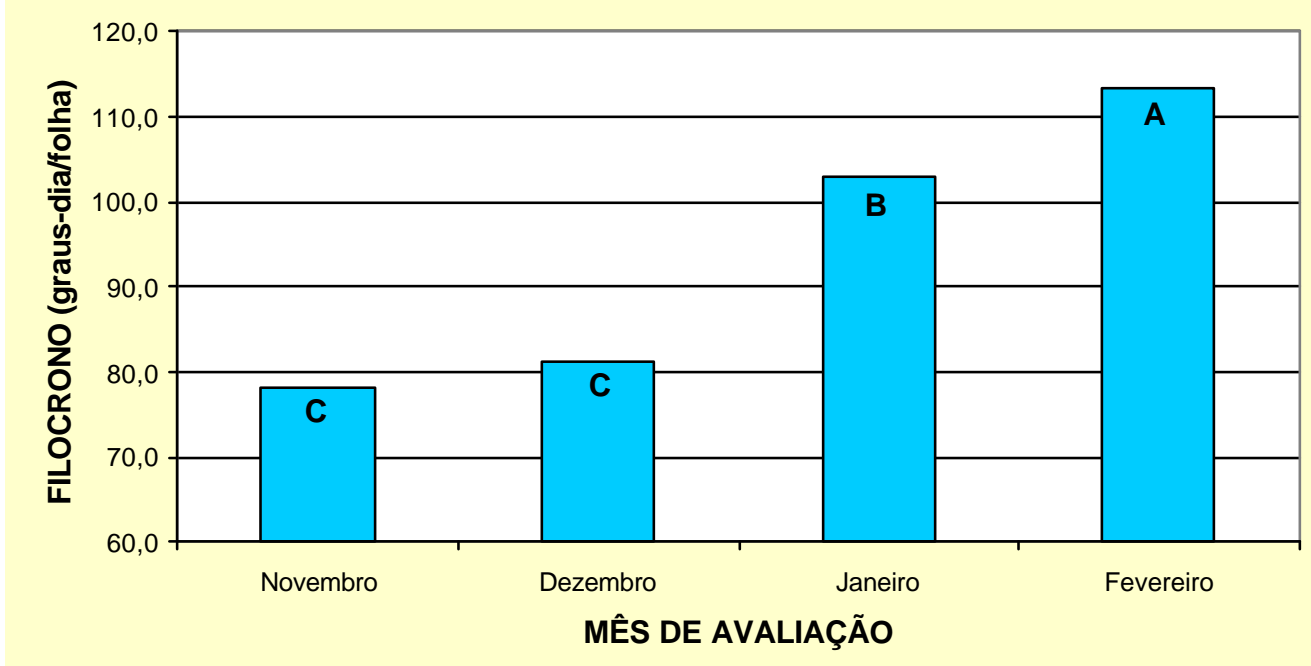

Figura 13 - Filocrono (graus-dia/folha) em pastos de capim Marandu, de novembro de 2001 a fevereiro de 2002.

\subsection{3 - Número médio de folhas vivas por perfilho}

Para o número de folhas vivas por perfilho (NFV) não houve efeito de altura do dossel forrageiro $(P=0,1831)$ nem de mês do ano $(P=0,8324)$. No entanto, foi constatado efeito da interação altura:mês $(P=0,0023)$. Os resultados são apresentados na Tabela 9 e Figura 14.

O NFV do capim Marandu no período estudado variou de 3,8 a 5,1 em fevereiro de 2002 no pasto mantido a $10 \mathrm{~cm}$ e em dezembro de 2001 no mantido a $40 \mathrm{~cm}$, respectivamente. A média geral de todo o período e de todos os tratamentos ficou ao redor de 4,5 folhas vivas por perfilho, valor bastante próximo ao encontrado por GOMIDE et al. (1997), que relataram 5 folhas vivas por perfilho, e pouco abaixo das 7 
folhas vivas por perfilho encontradas por CORSI et al. (1994), ambos em estudo com a mesma planta forrageira. Trabalhos com plantas forrageiras do mesmo gênero, como a braquiária decumbens, demonstraram valores ao redor de 5 folhas vivas por perfilho (CORSI et al., 1994; GOMIDE et al., 1997). Já BARBOSA et al. (1998), GOMIDE (1997) e OLIVEIRA et al. (1998) encontraram variação positiva no NFV durante a rebrotação ( 0 a 63 dias) até um valor máximo a partir do qual ocorreu um declínio em função do início do processo de senescência de tecidos (63 a 70 dias), atingindo um ponto de estabilização após decorrido algum tempo (70 dias).

Tabela 9. Número de folhas vivas por perfilho em pastos de capim Marandu mantidos em quatro alturas de dossel forrageiro, de novembro de 2001 a fevereiro de 2002.

\begin{tabular}{|c|c|c|c|c|c|c|}
\hline \multirow{2}{*}{ MÊS } & \multicolumn{4}{|c|}{ ALTURA (cm) } & \multirow{2}{*}{ MÉDIA } & \multirow{2}{*}{ EPM $^{*}$} \\
\hline & 10 & 20 & 30 & 40 & & \\
\hline Novembro & $4,4^{\mathrm{aA}}$ & $4,6^{\mathrm{aA}}$ & $4,7^{\mathrm{AA}}$ & $4,4^{\mathrm{aB}}$ & 4,5 & 0,14 \\
\hline Dezembro & $4,1^{\mathrm{bAB}}$ & $4,3^{\mathrm{bA}}$ & $4,3^{\mathrm{bA}}$ & $5,1^{\mathrm{aA}}$ & 4,5 & 0,14 \\
\hline Janeiro & $4,0^{\mathrm{aAB}}$ & $4,2^{\mathrm{aA}}$ & $4,4^{\mathrm{aA}}$ & $4,7^{\mathrm{aAB}}$ & 4,3 & 0,15 \\
\hline Fevereiro & $3,8^{\mathrm{bB}}$ & $4,6^{\mathrm{aA}}$ & $4,9^{\mathrm{aA}}$ & $4,8^{\mathrm{aA}}$ & 4,5 & 0,14 \\
\hline MÉDIA & 4,1 & 4,4 & 4,6 & 4,8 & & \\
\hline EPM $^{*}$ & 0,20 & 0,20 & 0,20 & 0,20 & & \\
\hline
\end{tabular}

EPIV - Erro padräo da média

Médias na linha seguidas de mesmas letras minúsculas não diferem entre si $(P \geq 0,10)$

Médias na coluna seguidas de mesmas letras maiúsculas não diferem entre si $(\mathbb{Z} \geq 0,10)$

Considerando os valores médios de NFV para as diferentes alturas de dossel forrageiro, percebe-se que esses valores foram relativamente constantes ( $P \geq 0,10$ ). Em seu estudo com Cynodon spp., PINTO (2000) também verificou ausência de efeito de altura do dossel forrageiro sobre o NFV.

Os resultados referentes a mês de avaliação não demonstraram ter havido efeito dessas estações do ano sobre o NFV $(P=0,8324)$. Outros autores encontraram respostas distintas, mostrando haver efeito de estação do ano sobre o NFV (SILVA et al., 1996; VAN ESBROECK et al., 1997). PACIULLO et al. (2002), estudando o capim 
Elefante (Pennisetum purpureum Schum.), observaram variação no NFV ao longo das estações do ano, com os maiores valores observados durante o verão (5,6 folhas), os menores durante o inverno (2,2 folhas) e valores intermediários durante a primavera e outono (4,2 e 4,5 folhas, respectivamente).

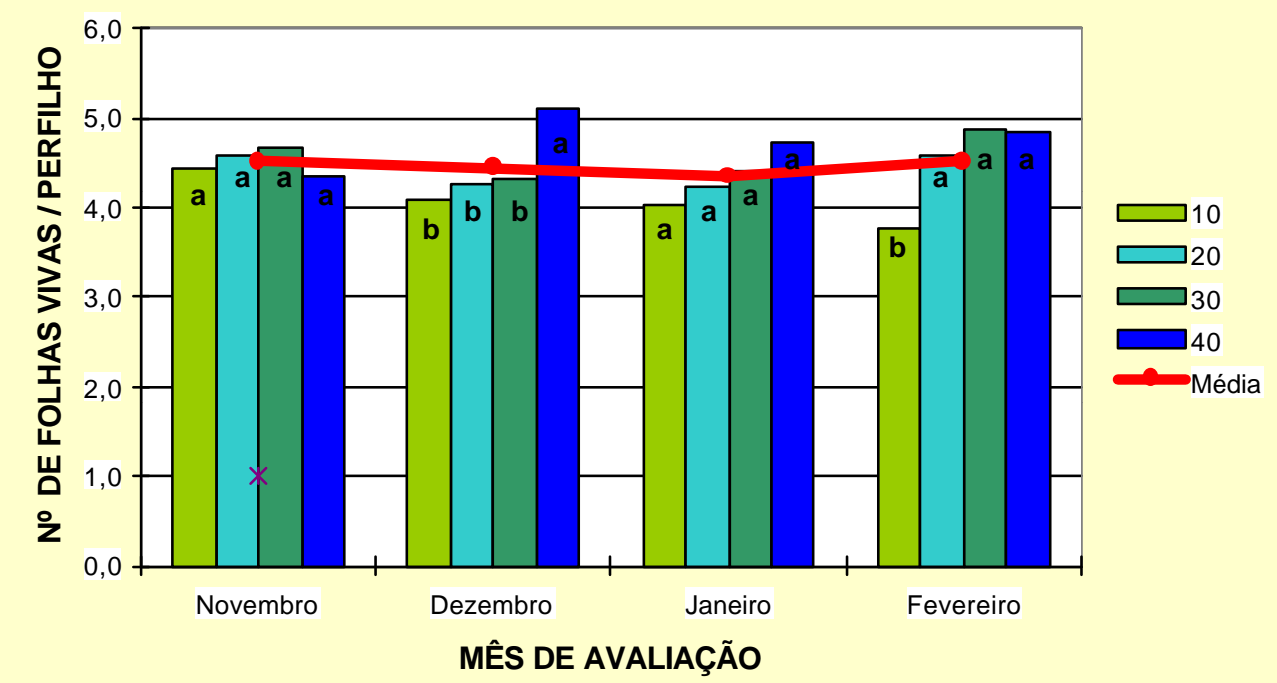

Figura 14 - Número de folhas vivas por perfilho em pastos de capim Marandu mantidos em quatro alturas de dossel forrageiro de novembro de 2001 a fevereiro de 2002.

No presente trabalho, em função da limitada duração do período experimental, as estações de primavera e verão foram representadas apenas parcialmente, na porção final da primavera e porção inicial do verão. Uma possível explicação para a ausência de efeito de época do ano é a falta de dados de toda a estação climática ou o reduzido distanciamento entre as épocas de avaliação, minimizando a amplitude de variação das respostas registradas.

Houve efeito da interação altura:mês $(P=0,0023)$. No mês de dezembro de 2001 o tratamento de $40 \mathrm{~cm}$ apresentou maior NFV que as demais alturas, que não diferiram entre si $(P \geq 0,10)$. Já em fevereiro de 2002, o tratamento de $10 \mathrm{~cm}$ apresentou o menor NFV. Nos demais meses nenhuma diferença $(P \geq 0,10)$ foi notada. 


\subsection{4 - Longevidade de folhas}

\subsubsection{1 - Expressa em dias}

A longevidade de folhas do capim Marandu expressa em dias (LF) sofreu efeito de altura do dossel forrageiro $(P=0,0005)$, mês do ano $(P<0,0001)$ e da interação altura:mês $(P=0,0056)$, como pode ser constatado na Tabela 10 e Figuras 15 e 16.

Tabela 10. Longevidade de folhas (dias) em pastos de capim Marandu mantidos em quatro alturas de dossel forrageiro, de novembro de 2001 a fevereiro de 2002.

\begin{tabular}{|c|c|c|c|c|c|c|}
\hline \multirow{2}{*}{ MÊS } & \multicolumn{4}{|c|}{ ALTURA (cm) } & \multirow{2}{*}{ MÉDIA } & \multirow{2}{*}{$\mathrm{EPM}^{\star}$} \\
\hline & 10 & 20 & 30 & 40 & & \\
\hline Novembro & $27,7^{\mathrm{bB}}$ & $33,0^{a b B}$ & $37,4^{\mathrm{aC}}$ & $38,2^{\mathrm{aC}}$ & $34,1^{\mathrm{D}}$ & 1,18 \\
\hline Dezembro & $31,5^{\mathrm{cB}}$ & $36,7^{\mathrm{bcB}}$ & $39,2^{a b c}$ & $43,4^{\mathrm{aC}}$ & $37,7^{\mathrm{C}}$ & 1,13 \\
\hline Janeiro & $38,4^{\mathrm{bA}}$ & $49,5^{\mathrm{aA}}$ & $45,6^{\mathrm{aB}}$ & $50,2^{a B}$ & $45,9^{B}$ & 1,13 \\
\hline Fevereiro & $40,2^{\mathrm{cA}}$ & $53,0^{\mathrm{bA}}$ & $59,8^{\mathrm{aA}}$ & $61,8^{\mathrm{aA}}$ & $53,7^{A}$ & 1,29 \\
\hline MÉDIA & $34,4^{c}$ & $43,1^{b}$ & $45,5^{a b}$ & $48,4^{a}$ & & \\
\hline EPM $^{*}$ & 1,44 & 1,50 & 1,44 & 1,59 & & \\
\hline
\end{tabular}

Os valores de LF variaram de 27,7 dias em novembro de 2001 para a altura de dossel forrageiro de $10 \mathrm{~cm}$ a 61,8 dias em fevereiro de 2002 para a altura de $40 \mathrm{~cm}$ (diferença de $123 \%$ do maior em relação ao menor). A média geral de todo o período experimental foi de 42,9 dias. Em virtude da pequena disponibilidade de informações relativas a LF de plantas forrageiras de clima tropical, tornou-se necessária a manipulação de dados referentes a NFV e TAF para calcular valores de LF de alguns experimentos relatados na literatura. Dos dados de CORSI et al. (1994), derivou-se a LF para braquiária brizanta de 37,1 a 46,9 dias, e das informações de GOMIDE et al. (1997) obteve-se valores de LF para braquiária decumbens que variaram de 35,5 a 
50,0 dias, valores esses compreendidos dentro da faixa de variação encontrada nos resultados do presente experimento.

A altura do dossel forrageiro exerceu efeito direto $(P=0,0005)$ sobre a $L F$ do capim Marandu, de forma que pastos mantidos mais altos (30 e $40 \mathrm{~cm}$ ) apresentaram maior LF que pastos mantidos a alturas menores (10 e $20 \mathrm{~cm}$ ) (Figura 15).

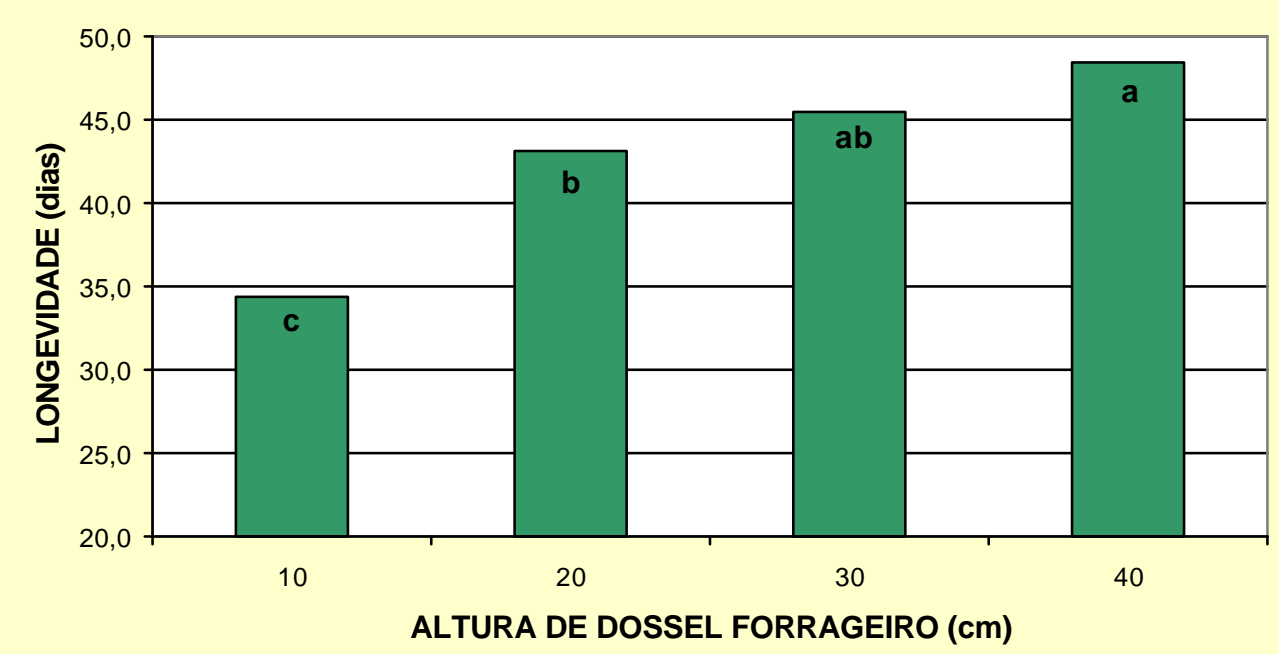

Figura 15 - Longevidade de folhas (dias) em pastos de capim Marandu mantidos em quatro alturas de dossel forrageiro.

Considerando que a LF deriva da multiplicação do NFV pelo filocrono, e que NFV não sofreu variação em relação a altura do pasto, pode-se concluir que foram as oscilações no valor de filocrono (Tabela 7) as maiores responsáveis pelas variações na LF aqui apresentadas. Outro efeito também significativo advém da maior freqüência e intensidade de desfolhação que os pastos mais baixos estiveram sujeitos (Tabelas 12 a 20), de forma que muitas de suas folhas desapareceram antes de findado seu ciclo fisiológico, ou seja, parte das folhas dos pastos mantidos mais baixos era removida antes de completar seu ciclo de vida (emergência/maturidade/senescência).

$O$ efeito de mês do ano sobre a LF foi acentuado ( $P<0,0001)$, aumentando os valores de LF àmedida que avançava o período experimental. Isso resultou em maior 
valor de LF em fevereiro de 2002 e menor em novembro de 2001 (Figura 16). Conforme já comentado sobre o efeito de altura do dossel sobre LF, também para mês de avaliação a influência nos valores de LF derivou das variações em filocrono (Tabela 7), uma vez que, novamente, o NFV permaneceu relativamente constante ao longo dos meses avaliados.

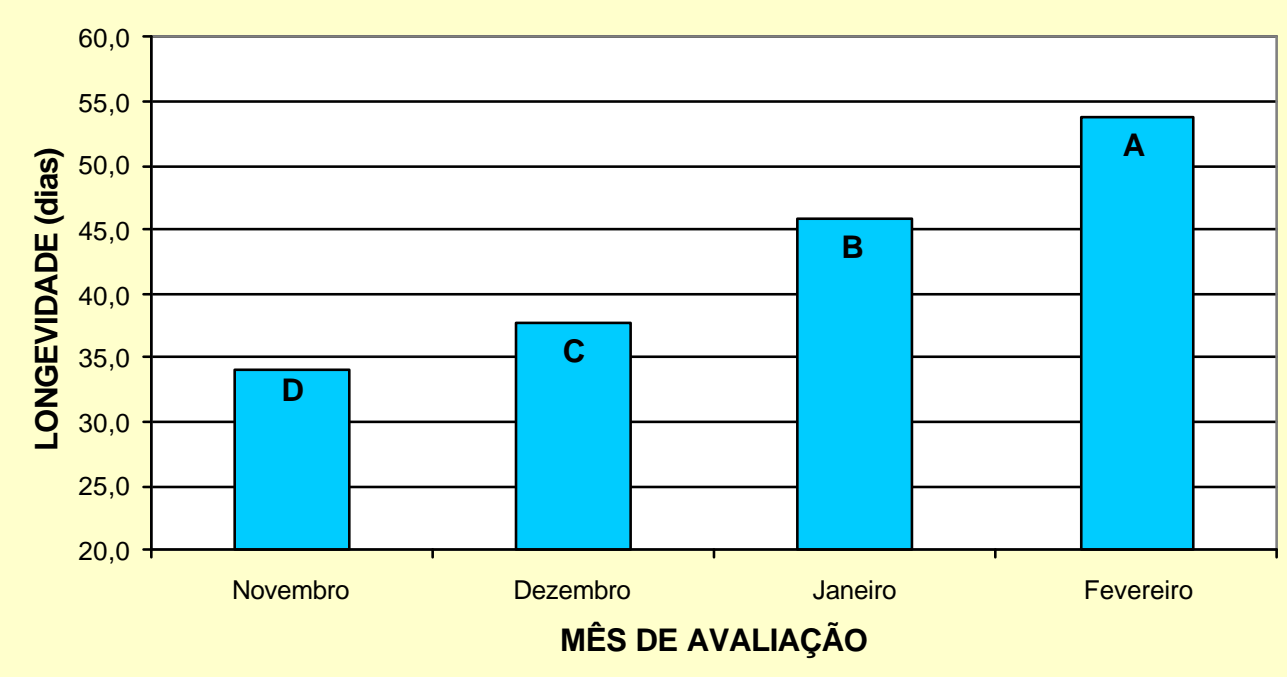

Figura 16 - Longevidade de folhas (dias) em pastos de capim Marandu de novembro de 2001 a fevereiro de 2002.

Com relação àinteração altura:mês $(P=0,0056)$, durante o mês de janeiro de 2002 as alturas de 20 e $30 \mathrm{~cm}$ apresentaram comportamento diferente daquele verificado nos demais meses, com valor numérico de longevidade maior na altura de $20 \mathrm{~cm}$ em relação a $30 \mathrm{~cm}$, e não um comportamento de elevação gradual da longevidade partindo da menor altura $(10 \mathrm{~cm})$ até a maior $(40 \mathrm{~cm})$.

\subsubsection{2 - Expressa em graus-dia}

A longevidade de folhas do capim Marandu expressa em graus-dia (LF-GD), assim como em $L F$, também sofreu efeito de altura do dossel forrageiro ( $P=0,0011)$, 
mês do ano $(P<0,0001)$ e da interação altura:mês $(P=0,0051)$. Esses resultados são apresentados na Tabela 11 e Figuras 17 e 18.

Tabela 11. Longevidade de folhas (graus-dias) em pastos de capim Marandu mantidos em quatro alturas de dossel forrageiro, de novembro de 2001 a fevereiro de 2002.

\begin{tabular}{|c|c|c|c|c|c|c|}
\hline \multirow{2}{*}{ MÊS } & \multicolumn{4}{|c|}{ ALTURA (cm) } & \multirow{2}{*}{ MÉDIA } & \multirow{2}{*}{ EPM } \\
\hline & 10 & 20 & 30 & 40 & & \\
\hline Novembro & $289,5^{\mathrm{bB}}$ & $368,4^{\mathrm{aB}}$ & $388,6^{\mathrm{aBC}}$ & $401,7^{\mathrm{aC}}$ & $362,0^{C}$ & 12,60 \\
\hline Dezembro & $300,6^{\mathrm{bB}}$ & $374,1^{a B}$ & $369,7^{\mathrm{aC}}$ & $411,1^{a C}$ & $363,9^{\mathrm{C}}$ & 12,15 \\
\hline Janeiro & $372,8^{\mathrm{bA}}$ & $490,8^{\mathrm{aA}}$ & $432,8^{\mathrm{aB}}$ & $477,0^{a B}$ & $443,3^{\mathrm{B}}$ & 12,15 \\
\hline Fevereiro & $365,5^{\mathrm{bA}}$ & $533,1^{\mathrm{aA}}$ & $542,7^{\mathrm{aA}}$ & $558,4^{\mathrm{aA}}$ & $499,9^{A}$ & 13,11 \\
\hline MÉDIA & $332,1^{b}$ & $441,6^{\mathrm{a}}$ & $433,5^{a}$ & $462,0^{\mathrm{a}}$ & & \\
\hline $\mathrm{EPM}^{*}$ & 15,45 & 15,59 & 15,45 & 16,93 & & \\
\hline
\end{tabular}

Os resultados revelaram valores de LF-GD oscilando de 289,5 graus-dia no pasto mantido a $10 \mathrm{~cm}$ em novembro de 2001 a 558,4 graus-dia no pasto mantido a 40 $\mathrm{cm}$ em fevereiro de 2002. O valor médio geral para o experimento de LF-GD foi de 417,3 graus-dia. Não foram encontradas informações na literatura que permitissem uma comparação dos dados encontrados com aqueles de outros autores para plantas tropicais. No entanto, para azevém perene e festuca valores correspondentes equivaleram a 330 e 540 graus-dia, respectivamente (LEMAIRE \& CHAPMAN, 1996). A diferença em termos absolutos entre esses valores e os obtidos neste experimento reflete apenas as diferenças morfológicas e fisiológicas entre as espécies de clima temperado e sub-tropical/tropical.

As alturas de dossel forrageiro de 20, 30 e $40 \mathrm{~cm}$ não apresentaram diferenças entre si $(P \geq 0,10)$, porém a altura de $10 \mathrm{~cm}$ diferenciou-se de todas as demais $(P<$ 0,10), apresentando o menor valor (Figura 17). Essa resposta de LF-GD, como 
esperado, acompanhou os resultados obtidos para F-GD, uma vez que o cálculo para sua obtenção derivou dele.

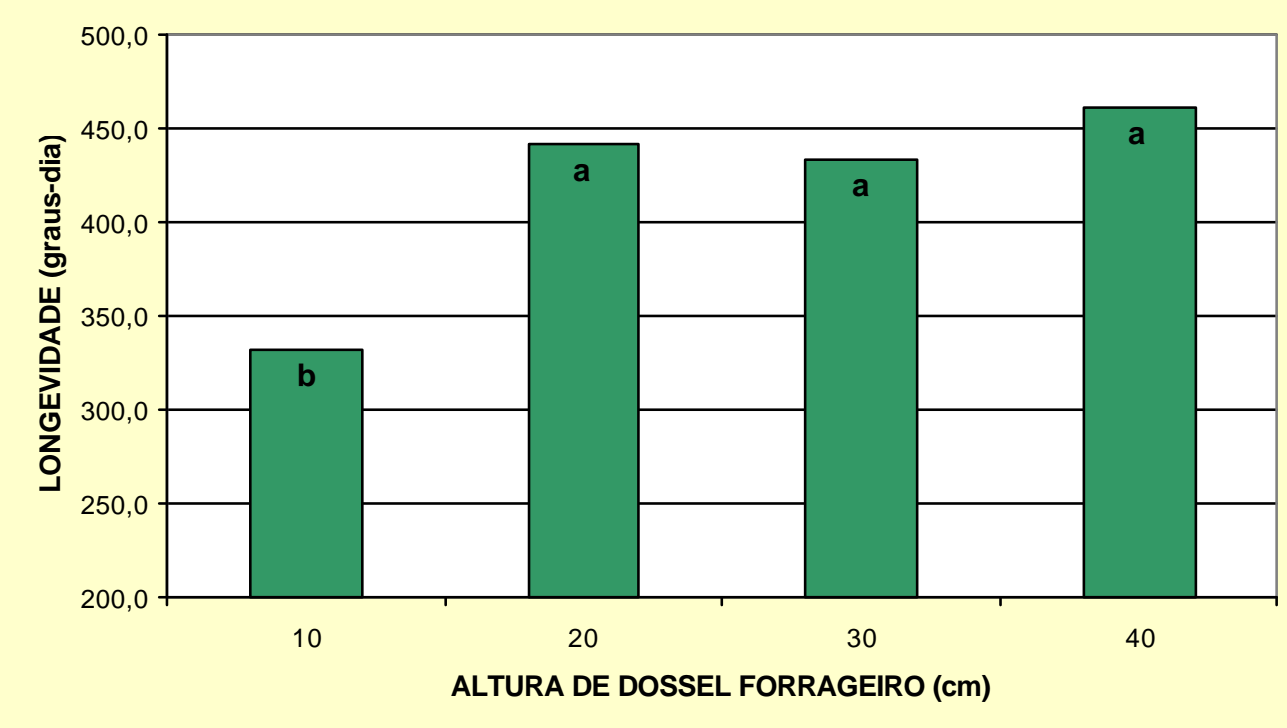

Figura 17 - Longevidade de folhas (graus-dia) em pastos de capim Marandu mantidos em quatro alturas de dossel forrageiro.

O efeito de mês do ano pode ser visualizado na Figura 18, onde os meses de novembro e dezembro de 2001 apresentaram menor valor de LF-GD que os demais ( $P$ $<0,10)$ sem diferirem entre si $(P \geq 0,10)$. $O$ mês de janeiro diferiu dos demais $(P<$ 0,10 ), apresentando valor de LF-GD intermediário, enquanto que em fevereiro de 2002 foi observado o maior valor de LF-GD $(P<0,10)$. Os valores de LF-GD obtidos estão diretamente relacionados aos valores de F-GD já descritos na Tabela 8, indicando que as variações em LF-GD são explicadas pelas variações em F-GD. 


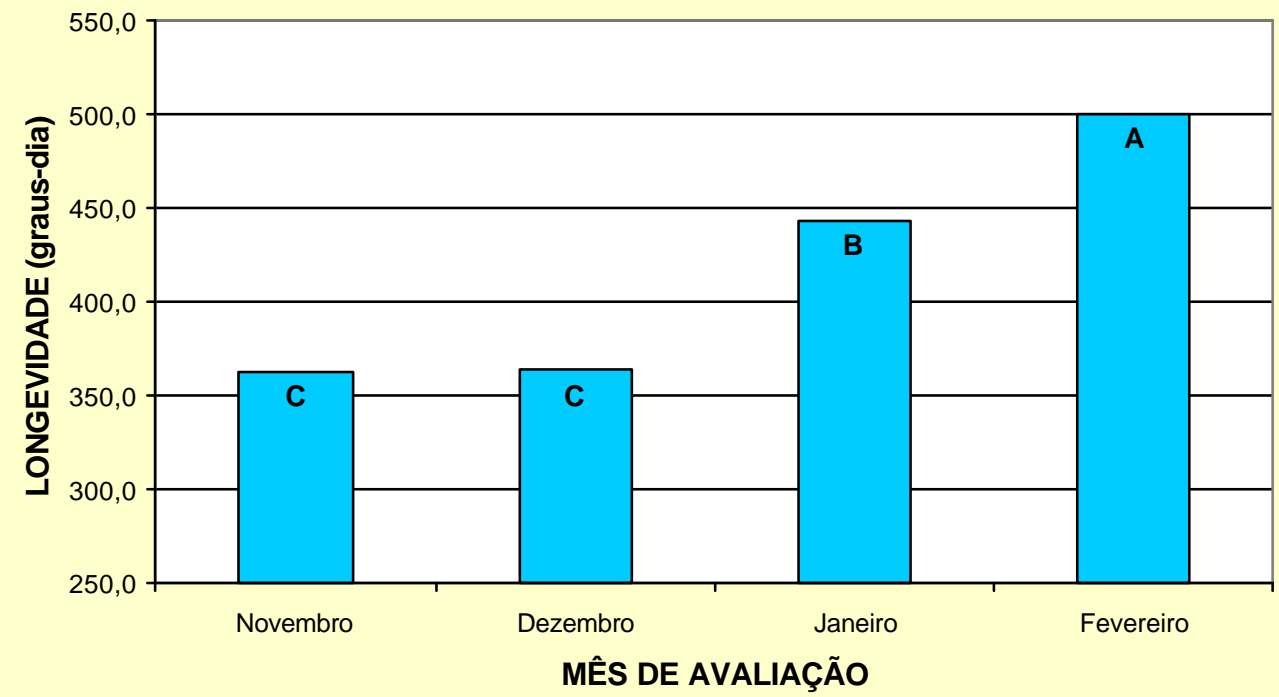

Figura 18 - Longevidade de folhas (graus-dia) em pastos de capim Marandu de novembro de 2001 a fevereiro de 2002.

Houve efeito da interação altura:mês $(P=0,0056)$. Durante o mês de janeiro a altura de pasto de $20 \mathrm{~cm}$ apresentou o maior valor de L-GD, também em dezembro de 2001 a altura de $20 \mathrm{~cm}$ apresentou valor elevado de L-GD em relação æ̀ demais alturas, contrariando o comportamento observado nos demais meses onde ocorreu uma elevação gradual dos valores de L-GD com o aumento da altura do pasto. Assim como observado para LF, as diferenças de comportamento observadas parecem ter origem no filoc rono, nesse caso no F-GD, visto que o NFV variou muito pouco.

\section{2 - PADRÕES DE DESFOLHAÇÃO}

\subsection{1 - Freqüência de desfolhação}

A avaliação da freqüência de desfolhação foi efetuada de formas distintas, considerando os efeitos diretos sobre o perfilho, sobre o perfilho estendido, sobre a 
folha e sobre o tipo de folha. O inverso da freqüência de desfolhação corresponde ao intervalo, em dias, entre duas desfolhações sucessivas.

\subsubsection{1 - Freqüência de desfolhação por perfilho}

Para freqüência de desfolhação por perfilho, a análise estatística demonstrou efeito de altura do dossel forrageiro $(P=0,0701)$ e de mês do ano $(P<0,0001)$, conforme demonstrado na Tabela 12. Não houve efeito da interação altura:mês $(P=$ $0,3382)$.

Tabela 12. Freqüência de desfolhação por perfilho (no de desfolhações/perfilho.dia) em pastos de capim Marandu mantidos em quatro alturas de dossel forrageiro, de novembro de 2001 a fevereiro de 2002.

\begin{tabular}{|c|c|c|c|c|c|c|}
\hline \multirow{2}{*}{ MÊS } & \multicolumn{4}{|c|}{ ALTURA $(\mathrm{cm})$} & \multirow{2}{*}{ MÉDIA } & \multirow{2}{*}{$\mathrm{EPM}^{*}$} \\
\hline & 10 & 20 & 30 & 40 & & \\
\hline Novembro & 0,086 & 0,079 & 0,083 & 0,088 & $0,084^{\mathrm{A}}$ & 0,0048 \\
\hline Dezembro & 0,087 & 0,069 & 0,068 & 0,047 & $0,068^{\mathrm{B}}$ & 0,0045 \\
\hline Janeiro & 0,079 & 0,079 & 0,086 & 0,073 & $0,079^{A}$ & 0,0043 \\
\hline Fevereiro & 0,055 & 0,046 & 0,032 & 0,016 & $0,037^{\mathrm{C}}$ & 0,0043 \\
\hline MÉDIA & $0,077^{\mathrm{a}}$ & $0,068^{\mathrm{a}}$ & $0,067^{a b}$ & $0,056^{b}$ & & \\
\hline EPM $^{*}$ & 0,0045 & 0,0043 & 0,0043 & 0,0048 & & \\
\hline
\end{tabular}

EPIV - Erro padrao da meda

Médias na linha seguidas de mesmas letras minúsculas não diferem entre si $(P \geq 0,10)$

Médias na coluna seguidas de mesmas letras maiúsculas não diferem entre si $(\mathbf{B} \geq 0,10)$

Ocorreu uma freqüência de desfolhação de perfilhos que variou de 0,016 a 0,088 evento/perfilho.dia nos pastos mantidos a $40 \mathrm{~cm}$ em fevereiro de $2002 \mathrm{e}$ naqueles mantidos a $40 \mathrm{~cm}$ em novembro de 2001, respectivamente. A transformação dos dados para o inverso da freqüência de desfolhação, ou seja, para o intervalo entre desfolhações sucessivas, permite uma maior facilidade de compreensão e visualização dos efeitos. Nesse caso, a amplitude de respostas variou de 11,4 a 61,5 dias entre 
desfolhações sucessivas para os meses de novembro de 2001 e fevereiro de 2002, respectivamente, ambos para pastos mantidos a $40 \mathrm{~cm}$ de altura.

São escassas informações pertinentes à freqüência de desfolhação de gramíneas forrageiras tropicais, sendo a maioria dos trabalhos conduzida com intervalos entre desfolhações pré-estabelecidos (períodos de descanso fixos) e/ou sem a mensuração real do intervalo entre as desfolhações, mas sim da duração dos ciclos de pastejo. Com base no exposto, a comparação dos resultados deste trabalho só pode ser feita em relação à literatura existente para plantas forrageiras de clima temperado, em especial para o azevém perene, que possui freqüências de desfolhação variando de 0,034 a 0,100 desfolhação por perfilho/dia, ou seja, 10 a 29 dias entre desfolhações sucessivas (WADE, 1991). Os valores encontrados para o capim Marandu apresentaram comportamento semelhante ao verificado para azevém perene, apenas em ordem de grandeza diferente, provavelmente conseqüência das diferenças morfológicas entre as espécies.

Foi detectado efeito de altura do dossel forrageiro sobre a freqüência de desfolhação de perfilhos ( $P=0,0701$ ), indicando que pastos mantidos mais baixos (10 e $20 \mathrm{~cm}$ ) foram desfolhados com maior freqüência que pastos mantidos mais altos (40 $\mathrm{cm}$ ), ficando aqueles mantidos a $30 \mathrm{~cm}$ em patamar intermediário de freqüência (Figura 19). Associação semelhante entre altura do dossel forrageiro e freqüência de desfolhação já havia sido demonstrada anteriormente para azevém perene por CARRÈRE et al. (2001), que encontraram 0,043 e 0,020 desfolhação por perfilho/dia para pastos baixos $(8 \mathrm{~cm})$ e altos $(12 \mathrm{~cm})$, respectivamente. A razão para essas variações na freqüência em função da altura do dossel forrageiro são devidas àmaior massa de forragem em pastos mais altos (Figura 4), permitindo ao animal consumir sua dieta diária sem precisar percorrer uma área maior do pasto o que resulta, consequentemente, numa menor freqüência de desfolhação de perfilhos individuais (PENNING et al., 1991).

O mês do ano também influenciou a freqüência de desfolhação por perfilho $(\mathrm{P}<$ 0,0001), sendo que os valores oscilaram ao longo do período experimental sem seguir um padrão específico relacionado com fatores climáticos ou edáficos. Nos meses de novembro de 2001 e janeiro de 2002 foram verificadas as maiores freqüências, as quais não diferiram entre si $(P \geq 0,10)$. Em dezembro de 2001 foi verificado valor 
intermediário de freqüência, enquanto que em fevereiro de 2002 foram registrados os menores valores (Figura 20).

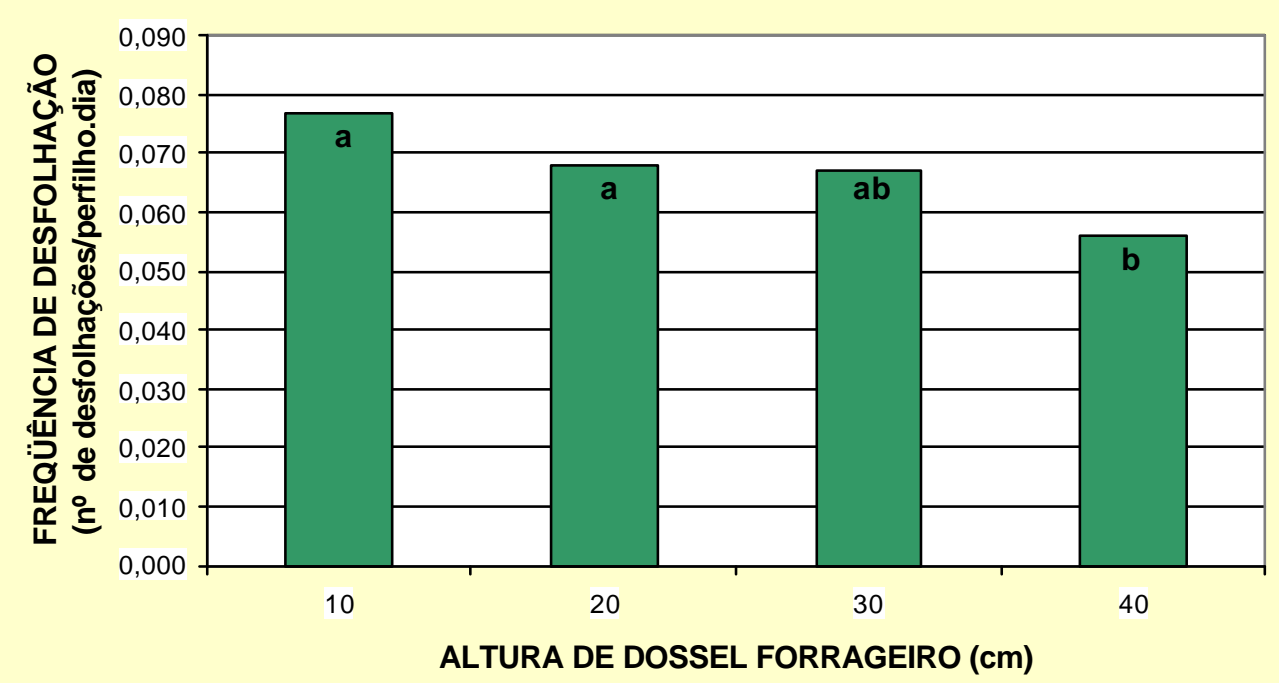

Figura 19 - Freqüência de desfolhação por perfilho em pastos de capim Marandu mantidos em quatro alturas de dossel forrageiro $(\mathrm{cm})$.

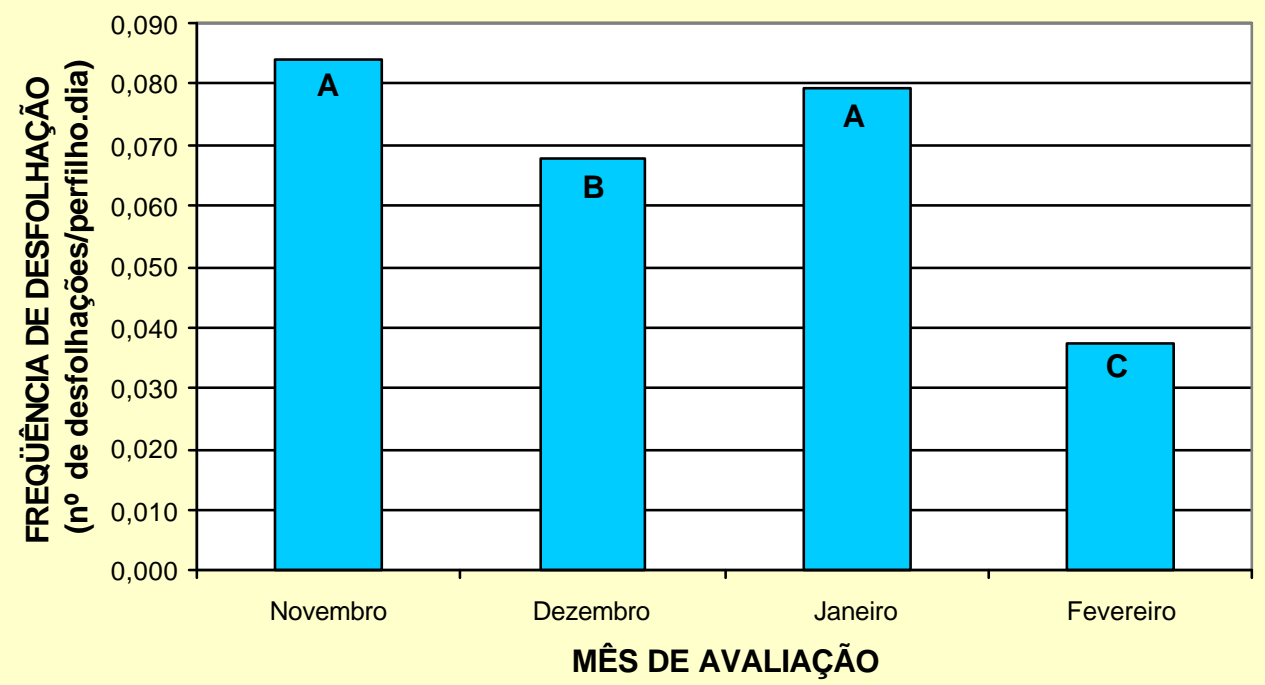

Figura 20 - Freqüência de desfolhação por perfilho em pastos de capim Marandu de novembro de 2001 a fevereiro de 2002. 
FENGRUI (2000), estudando o trevo branco, verificou haver correlação entre a freqüência de desfolhação e a taxa de aparecimento de folhas, indicando que àmedida que a TAF diminuia o mesmo ocorria para a freqüência de desfolhação. Já CARRÈRE et al. (2001), LACA et al. (1992) e SANTOS et al. (1999) mencionaram ser a massa de forragem derivada do maior ou menor crescimento da planta forrageira ao longo do ano a responsável pelas variações na freqüência. Entretanto, no presente experimento, essas considerações parecem não explicar completamente o observado, uma vez que no mês de janeiro houve uma maior freqüência de desfolhação apesar de não ter ocorrido o mesmo para TAF (Figura 7). Contudo, variações em freqüência de desfolhação por perfilho acompanharam aquelas observadas para os valores de capacidade de suporte ( $\mathrm{kg}$ de PV/ha.dia) registrados ao longo do período experimental ${ }^{2}$ (Figura 21). Esse comportamento também foi verificado por WADE (1991) em seu estudo com azevém perene e festuca, onde foi constatada a existência de uma relação direta e linear entre capacidade de suporte ( $\mathrm{kg}$ de $\mathrm{PV} / \mathrm{ha}$.dia) e freqüência de desfolhação, sendo que cada vez que a capacidade de suporte era elevada maior era a freqüência de desfolhação correspondente (menor o intervalo entre desfolhações sucessivas).

No final do mês de janeiro de 2002 foi necessário promover a manutenção dos animais "testers" de cada parcela experimental durante um período de tempo maior que aquele previsto pelo protocolo de ajuste em taxa de lotação para que outras informações sendo levantadas em experimento concomitante na mesma área experimental pudessem ser coletadas. O reflexo dessa maior carga animal no final de janeiro de 2002 acabou por reduzir a altura média das parcelas (Figura 3), particularmente nos pastos de 30 e $40 \mathrm{~cm}$, o que causou a necessidade de reduzir as taxas de lotação em fevereiro de 2002, resultando na diminuição observada em freqüência de desfolhação dos perfilhos.

Esses resultados permitiram estabelecer uma associação semelhante àquela efetuada para azevém perene por WADE (1991), através da relação entre o logaritmo natural da área pastejada diariamente (\% da área total), equivalente à freqüência de desfolhação expressa em porcentagem (x100) (LEMAIRE \& CHAPMAN, 1996), e o

\footnotetext{
2 ANDRADE, F. M. E. (Escola Superior de Agricultura "Luiz de Queiroz", Piracicaba, SP). Valor nutritivo da forragem e desempenho de bovinos de corte em pastos de Brachiaria brizantha cv. Marandu (projeto de mestrado em andamento).
} 
logaritmo da capacidade de suporte da pastagem (kg de PV/ha.dia). Oresultado obtido é apresentado na Figura 22.

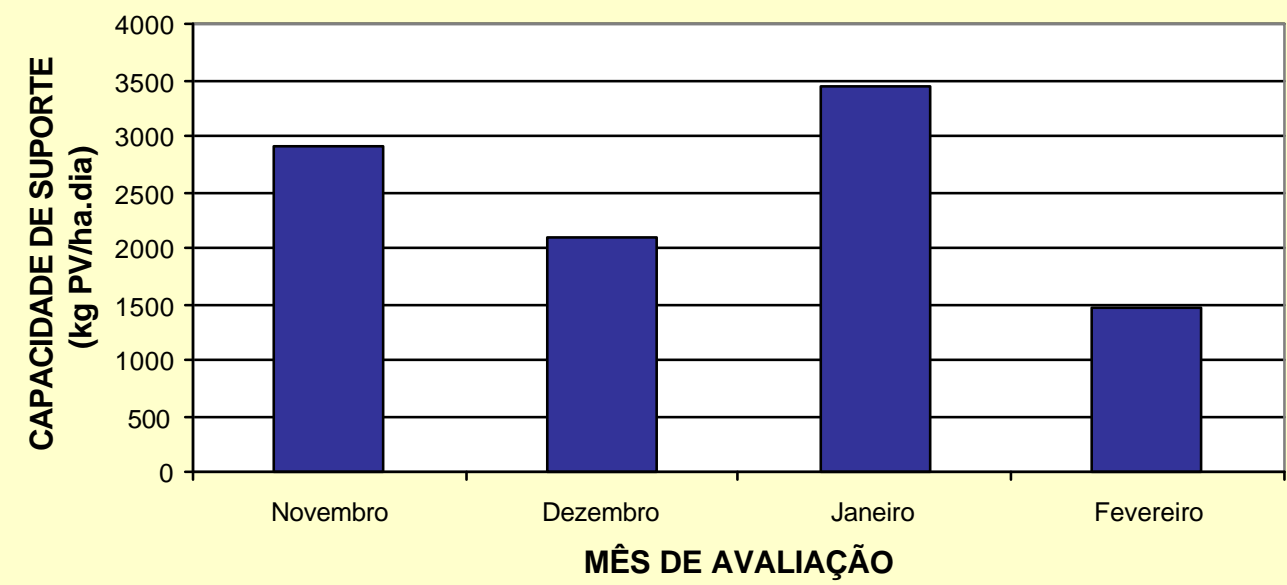

Figura 21 - Capacidade de suporte (kg PV/ha.dia) ao longo do período experimental.

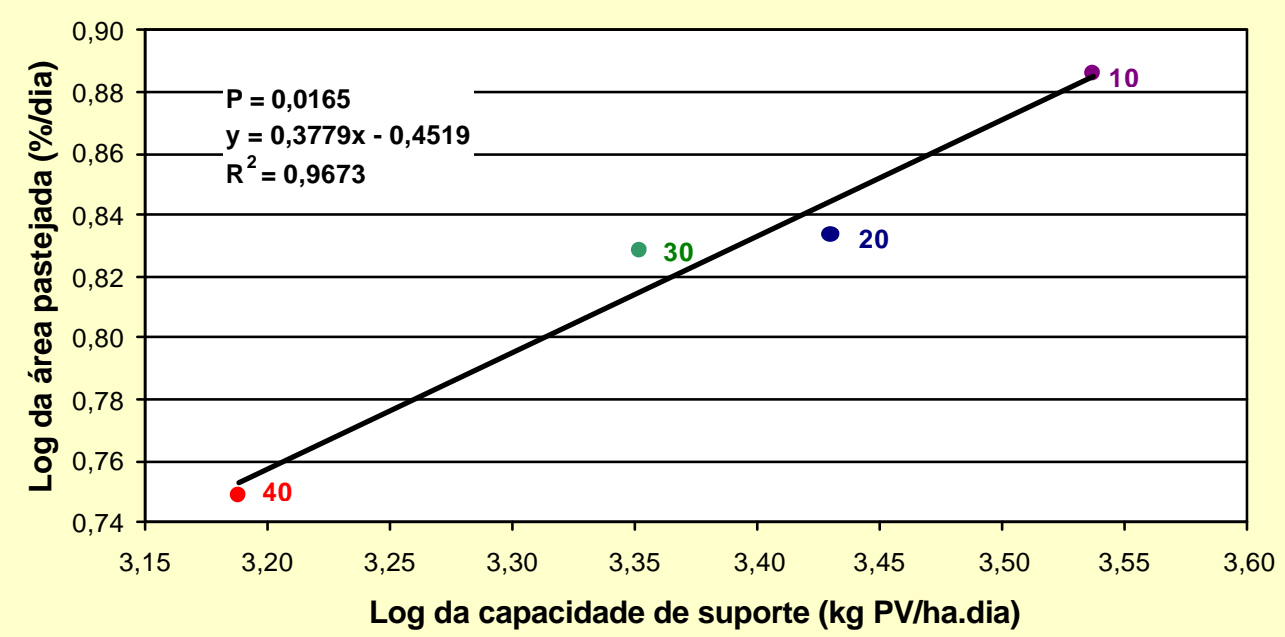

Figura 22 - Relação entre área pastejada por dia (freqüência de desfolhação por perfilho) e capacidade de suporte ( $\mathrm{kg}$ PV/ha.dia) em pastos de capim Marandu mantidos em quatro alturas de dossel forrageiro $(\mathrm{cm})$ de novembro de 2001 a fevereiro de 2002. 
O capim Marandu, assim como o azevém perene estudado por WADE (1991), também apresentou resposta linear em freqüência de desfolhação (\% pastejada da área total) em relação a capacidade de suporte ( $\mathrm{kg}$ de PV/ha.dia), indicando a forte influência que variações em taxa de lotação têm sobre a freqüência de desfolhação de perfilhos e seu papel estratégico como ferramenta no manejo do pastejo e otimização da utilização da forragem produzida.

\subsubsection{2 - Freqüência de desfolhação por perfilho estendido}

Outra maneira utilizada para chegar àfreqüência de desfolhação por perfilho foi considerando a altura estendida do perfilho. Essa forma de avaliação é menos criteriosa que a anterior, uma vez que considera a ocorrência de um evento (desfolhação) apenas quando a altura estendida do perfilho apresenta-se reduzida em relação àmedição anterior. Nos casos onde ocorria desfolhação, porém em folhas que não definiam o comprimento estendido do perfilho, não era computado o evento. Esse efeito foi agravado pelo comprimento considerável das folhas do capim Marandu. As diferenças entre a forma de quantificar a freqüência de desfolhação acabaram por influir nos resultados, que embora apresentem o mesmo comportamento geral, mostram escalas de valores diferentes. Esta forma de avaliação foi utilizada por se tratar de como as avaliações no trabalho clássico de WADE (1991) foram realizadas, visando uma eventual comparação de resultados.

A freqüência de desfolhação por perfilho estendido sofreu efeito de altura do dossel forrageiro $(P=0,0397)$, mês do ano $(P<0,0001)$, e da interação altura:mês ( $P=$ 0,0264), conforme resultados apresentados na Tabela 13 e Figura 23.

Os valores apurados indicaram uma faixa de freqüência de desfolhação por perfilho estendido variando de 0,019 a 0,072 evento/perfilho estendido.dia para a altura de $30 \mathrm{~cm}$ em fevereiro de 2002 e $10 \mathrm{~cm}$ em janeiro de 2002, respectivamente. A média geral dos valores apurados foi de 0,051 evento/perfilho estendido.dia, inferior àquela de 0,067 evento/perfilho.dia registrada para perfilhos não estendidos (item 4.2.1.1). Transformando os valores para intervalo entre desfolhações sucessivas, obteve-se uma amplitude de 13,9 a 52,1 dias, ficando a média geral em 19,4 dias entre desfolhações. Os valores estão compreendidos dentro da faixa encontrada para freqüência por perfilho (item 4.2.1.1). 
Tabela 13. Freqüência de desfolhação por perfilho estendido ( $n^{0}$ de desfolhações/perfilho estendido.dia) em pastos de capim Marandu mantidos em quatro alturas de dossel forrageiro, de novembro de 2001 a fevereiro de 2002.

\begin{tabular}{|c|c|c|c|c|c|c|}
\hline \multirow{2}{*}{ MÊS } & \multicolumn{4}{|c|}{ ALTURA (cm) } & \multirow{2}{*}{ MÉDIA } & \multirow{2}{*}{$\mathrm{EPM}^{\star}$} \\
\hline & 10 & 20 & 30 & 40 & & \\
\hline Novembro & $0,060^{\mathrm{aB}}$ & $0,060^{\mathrm{aAB}}$ & $0,065^{\mathrm{aA}}$ & $0,058^{\mathrm{aA}}$ & $0,061^{A}$ & 0,0028 \\
\hline Dezembro & $0,069^{\mathrm{aAB}}$ & $0,066^{\mathrm{aA}}$ & $0,057^{\mathrm{abAB}}$ & $0,044^{\mathrm{bB}}$ & $0,059^{A}$ & 0,0028 \\
\hline Janeiro & $0,072^{\mathrm{aA}}$ & $0,055^{\mathrm{bB}}$ & $0,052^{\mathrm{bB}}$ & $0,048^{\mathrm{bAB}}$ & $0,057^{\mathrm{A}}$ & 0,0027 \\
\hline Fevereiro & $0,047^{\mathrm{aC}}$ & $0,026^{\mathrm{bC}}$ & $0,019^{b C}$ & $0,024^{b C}$ & $0,029^{B}$ & 0,0029 \\
\hline MÉDIA & $0,062^{\mathrm{a}}$ & $0,052^{b}$ & $0,048^{b}$ & $0,044^{b}$ & & \\
\hline EPM $^{*}$ & 0,0038 & 0,0037 & 0,0037 & 0,0039 & & \\
\hline
\end{tabular}

EPM* - Erro padrão da média

Médias na linha seguidas de mesmas letras minúsculas não diferem entre si $(P>0,10)$

Médias na coluna seguidas de mesmas letras maiúsculas não diferem entre si $(\mathbb{Z} \geq 0,10)$

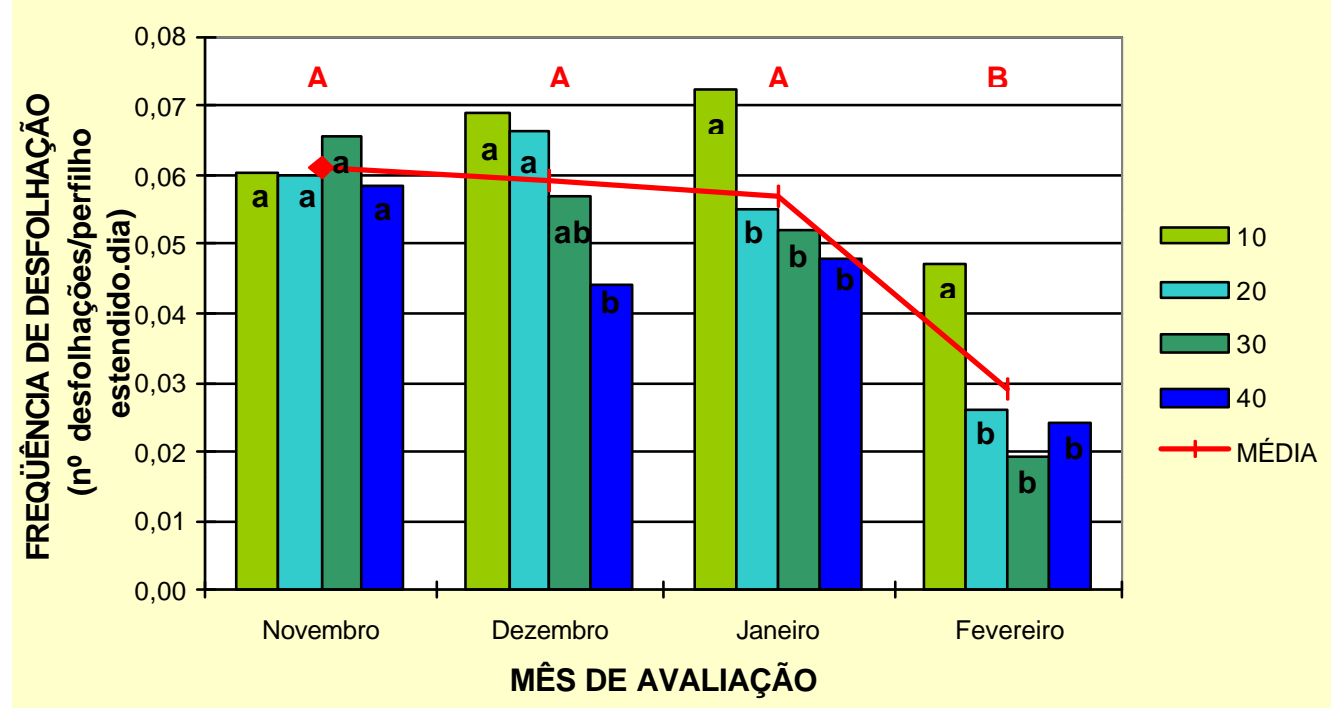

Figura 23 - Freqüência de desfolhação por perfilho estendido em pastos de capim Marandu mantidos em quatro alturas de dossel forrageiro $(\mathrm{cm})$, de novembro de 2001 a fevereiro de 2002. 
Houve efeito de altura do dossel forrageiro sobre a freqüência de desfolhação por perfilho estendido ( $P=0,0397$ ), sendo que pastos mantidos a $10 \mathrm{~cm}$ foram desfolhados com maior freqüência (0,062 evento/perfilho estendido.dia) que pastos mantidos a 20, 30 e $40 \mathrm{~cm}$, os quais não diferiram entre si ( $\geq 0,10)$, embora apresentassem uma tendência decrescente de valores (Tabela 13). A menor massa de forragem nos pastos mantidos a $10 \mathrm{~cm}$ foi a principal responsável pela maior freqüência de desfolhação observada, uma vez que na tentativa de ingerir a mesma quantidade de forragem que os animais mantidos nos pastos mais altos (20, 30 e 40 $\mathrm{cm}$ ) foi necessário pastejar uma área maior da parcela diariamente (maior freqüência de desfolhação).

Quanto ao mês do ano ( $P=0,0264)$, os meses de novembro e dezembro de 2001 e janeiro de 2002 apresentaram valores semelhantes de freqüência de desfolhação por perfilho estendido $(P \geq 0,10)$, enquanto que no mês de fevereiro de 2002 foi registrado valor inferior aos demais meses $(P<0,10)$. No caso específico da freqüência de desfolhação por perfilho estendido, os valores verificados parecem acompanhar aqueles da TAF (Figura 7), estando a freqüência de janeiro de 2002 inflacionada em virtude da manutenção de animais "testers" na área experimental, o que causou redução das alturas médias previstas de manutenção do dossel forrageiro e aumentou a freqüência de desfolhação por perfilho estendido. O inverso ocorreu durante o mês de fevereiro, quando os pastos foram mantidos sob uma baixa carga animal para que restabelecessem as alturas médias dos tratamentos experimentais.

Durante o mês de novembro de 2001 não ocorreram diferenças em freqüência de desfolhação por perfilho estendido entre as alturas de dossel forrageiro estudadas $(P \geq 0,10)$, contraditoriamente àquilo que foi observado nos demais meses, onde 0 efeito de altura do pasto foi claro $(P<0,10)$. Esse fato pode ter sido conseqüência do maior tamanho das folhas basais (próximas do nível do solo) em relação à superiores (contidas no estrato superior do dossel, horizonte de pastejo dos animais). GOMIDE (1997), trabalhando com Panicum maximum (Jacq.) cv. Tanzânia e Mombaça, revelou que as folhas surgidas ao longo do período de rebrotação das plantas apresentavam tamanhos crescentes inicialmente e decrescentes após transcorrido algum tempo, conseqüência do alongamento de hastes e redução da distância a ser percorrida pelas folhas novas até sua exposição àluz, no topo do dossel forrageiro. Em azevém perene esse período de tempo corresponde a duas vezes o tempo necessário para renovar o 
número de folhas do perfilho (HODGSON, 1990). CARVALHO (2002), trabalhando com capim Mombaça e Tanzânia obteve um tempo médio semelhante em termos de renovação do número de folhas por perfilho, ou seja, 2 a 2,5. No presente experimento, o corte de uniformização foi realizado no final de agosto e a primeira avaliação somente realizada no dia 12 de novembro, ou seja, um período de cerca de 75 dias. Considerando-se o número médio de folhas por perfilho de 4,5 (Tabela 9, novembro), um filocrono médio de 7,4 dias por folha de setembro a novembro (Tabela 7) e o intervalo de tempo correspondente a duas vezes o número de folhas por perfilho ( 2 x 4,5 = 9 folhas), obtém-se o valor de 67 dias, período a partir do qual as folhas novas eram, realmente, menores que as basais. Esse fato já não se repetiu mais de dezembro em diante, uma vez que as comunidades de plantas encontravam-se em equilíbrio dinâmico após estabilização das condições experimentais.

Assim como para os resultados de freqüência de desfolhação por perfilho (item 4.2.1.1), no caso do perfilho estendido também foram relacionados os valores de freqüência de desfolhação, tabulados sob a forma de logaritmo natural da porcentagem da área pastejada diariamente, com os valores de capacidade de suporte (kg de PV/ha.dia) correspondentes, tabulados como logaritmo natural da capacidade de suporte, originando a Figura 24 a seguir. Novamente, a forte relação entre taxa de lotação e freqüência de desfolhação foi evidenciada, corroborando os resultados de WADE (1991) em trabalho clássico com pastagens de azevém perene e festuca. 


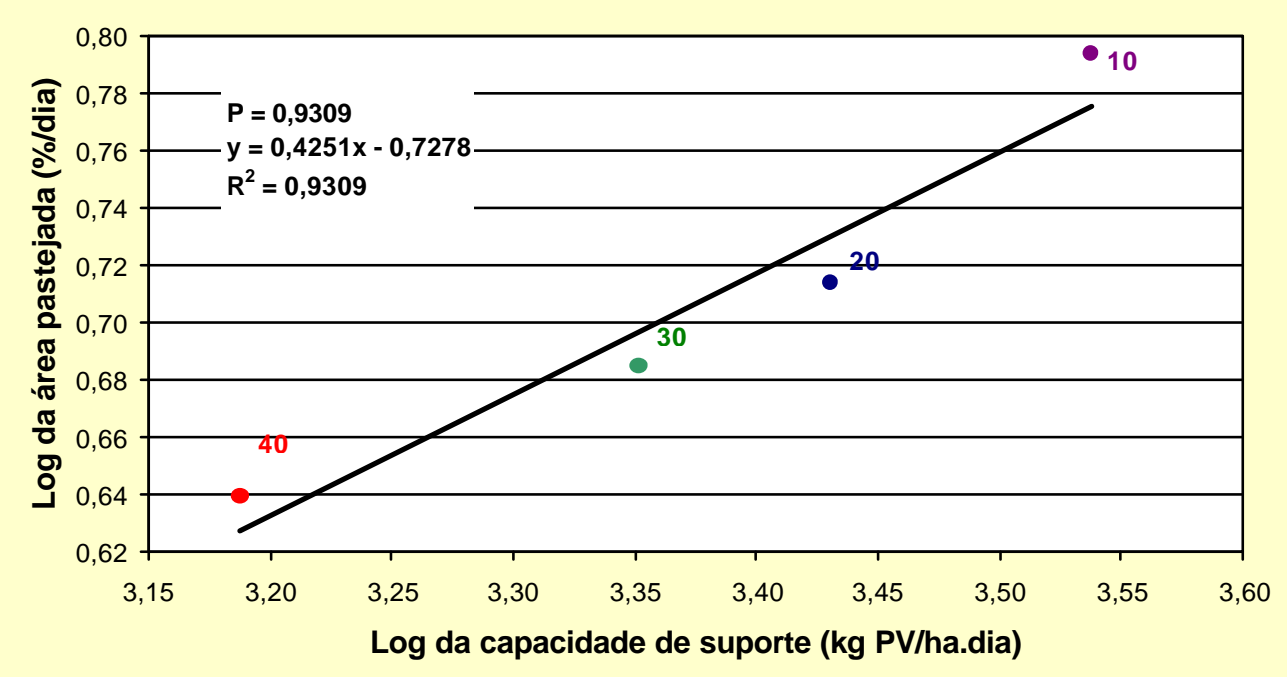

Figura 24 - Relação entre área pastejada por dia (freqüência de desfolhação por perfilho estendido) e capacidade de suporte (kg PV/ha.dia) em pastos de capim Marandu mantidos em quatro alturas de dossel forrageiro $(\mathrm{cm})$, de novembro de 2001 a fevereiro de 2002.

\subsubsection{3 - Freqüência de desfolhação por folha}

Foi registrado efeito de altura do dossel forrageiro $(P=0,0062)$ e mês do ano ( $P$ $<0,0001$ ), como pode ser observado na Tabela 14. Não houve efeito da interação altura:mês $(P=0,4244)$.

As folhas dos perfilhos avaliados apresentaram valor de freqüência de desfolhação média de 0,033 evento/dia, correspondente a 30,3 dias entre desfolhações sucessivas. No entanto, a amplitude de variação de respostas foi muito grande, desde 0,009 evento/dia (altura de $40 \mathrm{~cm}$ em fevereiro de 2002) até 0,053 evento/dia (altura de $10 \mathrm{~cm}$ em janeiro de 2002), correspondentes a 111,1 e 18,9 dias, respectivamente. Também para freqüência de desfolhação por folha, a ausência de informações para plantas forrageiras de clima tropical força comparações com plantas de clima temperado. HU (1993), em seu estudo com azevém perene, encontrou valores de freqüência de desfolhação por folha variando de 0,090 a 0,122 desfolhação/dia, valores 
esses superiores aos observados no presente trabalho e provavelmente conseqüência das alturas mais baixas utilizadas em suas condições experimentais.

Tabela 14. Freqüência de desfolhação por folha (no de desfolhações/folha.dia) em pastos de capim Marandu mantidos em quatro alturas de dossel forrageiro, de novembro de 2001 a fevereiro de 2002.

\begin{tabular}{|c|c|c|c|c|c|c|}
\hline \multirow{2}{*}{ MÊS } & \multicolumn{4}{|c|}{ ALTURA $(\mathrm{cm})$} & \multirow{2}{*}{ MÉDIA } & \multirow{2}{*}{ EPM $^{*}$} \\
\hline & 10 & 20 & 30 & 40 & & \\
\hline Novembro & 0,040 & 0,038 & 0,036 & 0,040 & $0,039^{A}$ & 0,0026 \\
\hline Dezembro & 0,044 & 0,032 & 0,031 & 0,020 & $0,032^{B}$ & 0,0026 \\
\hline Janeiro & 0,053 & 0,042 & 0,039 & 0,033 & $0,042^{A}$ & 0,0027 \\
\hline Fevereiro & 0,037 & 0,022 & 0,016 & 0,009 & $0,021^{\mathrm{C}}$ & 0,0026 \\
\hline MÉDIA & $0,043^{a}$ & $0,033^{b}$ & $0,031^{b c}$ & $0,026^{c}$ & & \\
\hline EPM $^{*}$ & 0,0027 & 0,0026 & 0,0026 & 0,0026 & & \\
\hline
\end{tabular}

Médias na linha seguidas de mesmas letras minúsculas não diferem entre si $(P>0,10)$

Médias na coluna seguidas de mesmas letras maiúsculas não diferem entre si $(\mathbb{Z} \geq 0,10)$

Houve efeito negativo de altura do dossel forrageiro sobre a freqüência de desfolhação, ou seja, pastos mantidos mais altos apresentaram menor freqüência de desfolhação por folha (Figura 25). A altura de $10 \mathrm{~cm}$ demonstrou uma freqüência de desfolhação média por folha superior aos demais tratamentos $(P<0,10)$. As alturas de 20 e $30 \mathrm{~cm}$ não diferiram entre si $(P \geq 0,10)$, e a altura de $40 \mathrm{~cm}$ apresentou o menor valor de freqüência de desfolhação $(P<0,10)$, embora semelhante àquele da altura de $30 \mathrm{~cm}(P \geq 0,10)$. Os resultados encontrados neste experimento corroboram aqueles obtidos por LUCENA et al. (2002), HU (1993) e WADE (1991) em seus estudos com azevém perene, demonstrando haver forte influência da altura do pasto (massa de forragem) sobre a freqüência de desfolhação de perfilhos individuais. Esses autores verificaram que à medida que havia maior massa de forragem nos pastos (dossel forrageiro mais elevado) menor era a freqüência de desfolhação dos perfilhos. O maior efeito em pastos mantidos a $10 \mathrm{~cm}$ poderia ainda estar associado à dificuldade dos bovinos em apreender o alimento (capim) quando esse apresenta-se em alturas de 
dossel forrageiro inferiores a 8 a $10 \mathrm{~cm}$ (HODGSON, 1990), reduzindo seu consumo especialmente no caso de plantas forrageiras tropicais, onde há maior participação de hastes nessa altura.

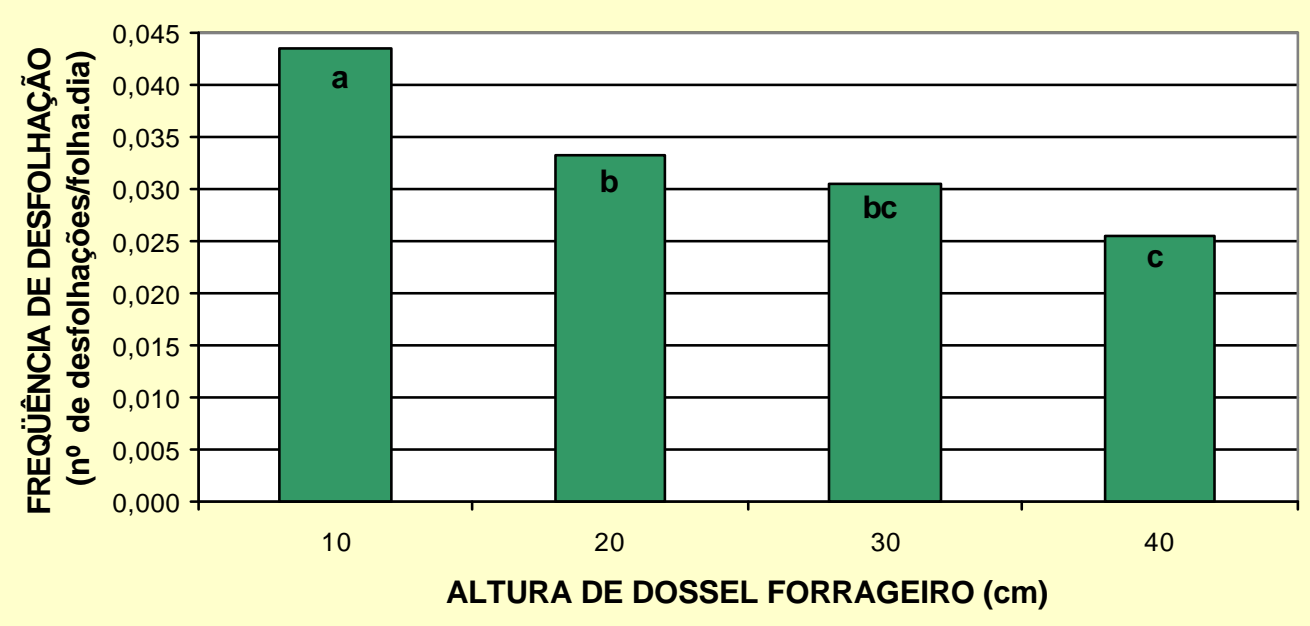

Figura 25 - Freqüência de desfolhação por folha em pastos de capim Marandu mantidos em quatro alturas de dossel forrageiro $(\mathrm{cm})$.

O efeito de mês do ano sobre a freqüência de desfolhação por folha está ilustrado na Figura 26. Os valores mais altos ocorreram em novembro de $2001 \mathrm{e}$ janeiro de 2002, os quais não diferiram entre si $(P \geq 0,10)$. Em dezembro de 2001 foi registrado valor superior àquele de fevereiro de 2002, porém inferior àqueles de novembro de 2001 e janeiro de 2002 ( $P<0,10)$. Esses resultados acompanharam as variações em capacidade de suporte que foi utilizada na área experimental para manutenção das alturas de dossel forrageiro (Figura 21), revelando a associação entre freqüência de desfolhação e capacidade de suporte durante o período experimental (Figura 27) e corroborando os resultados de WADE (1991). 


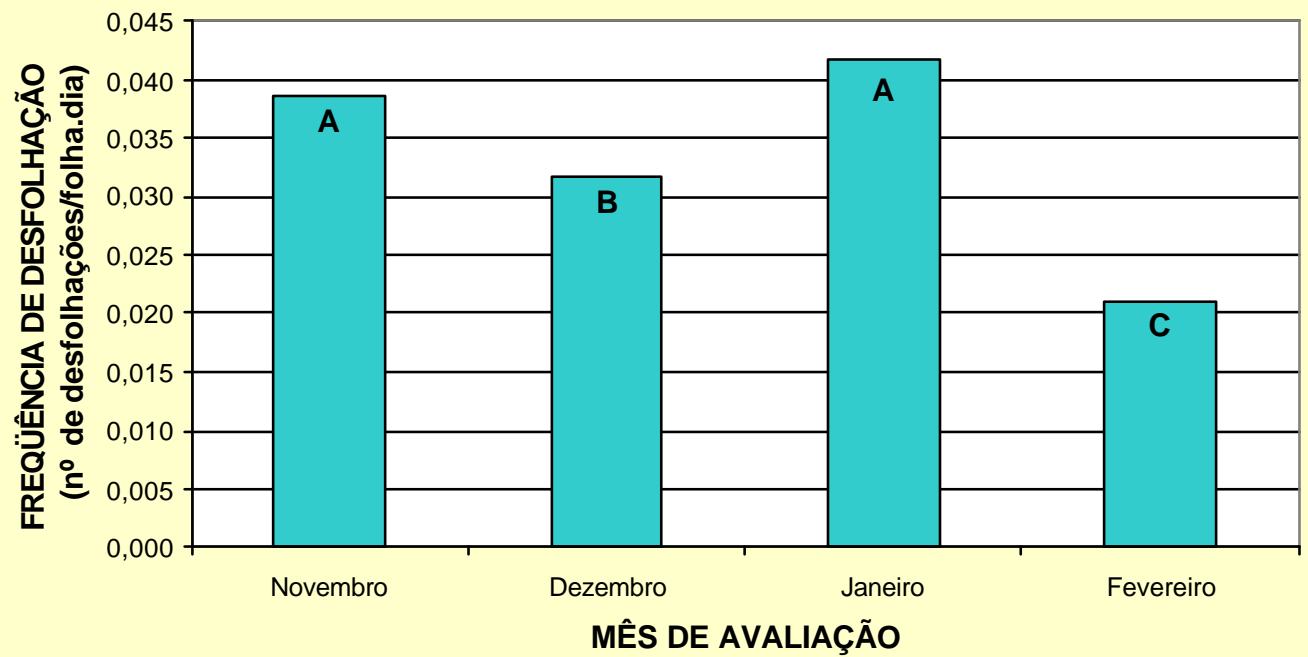

Figura 26 - Freqüência de desfolhação por folha em pastos de capim Marandu de novembro de 2001 a fevereiro de 2002.

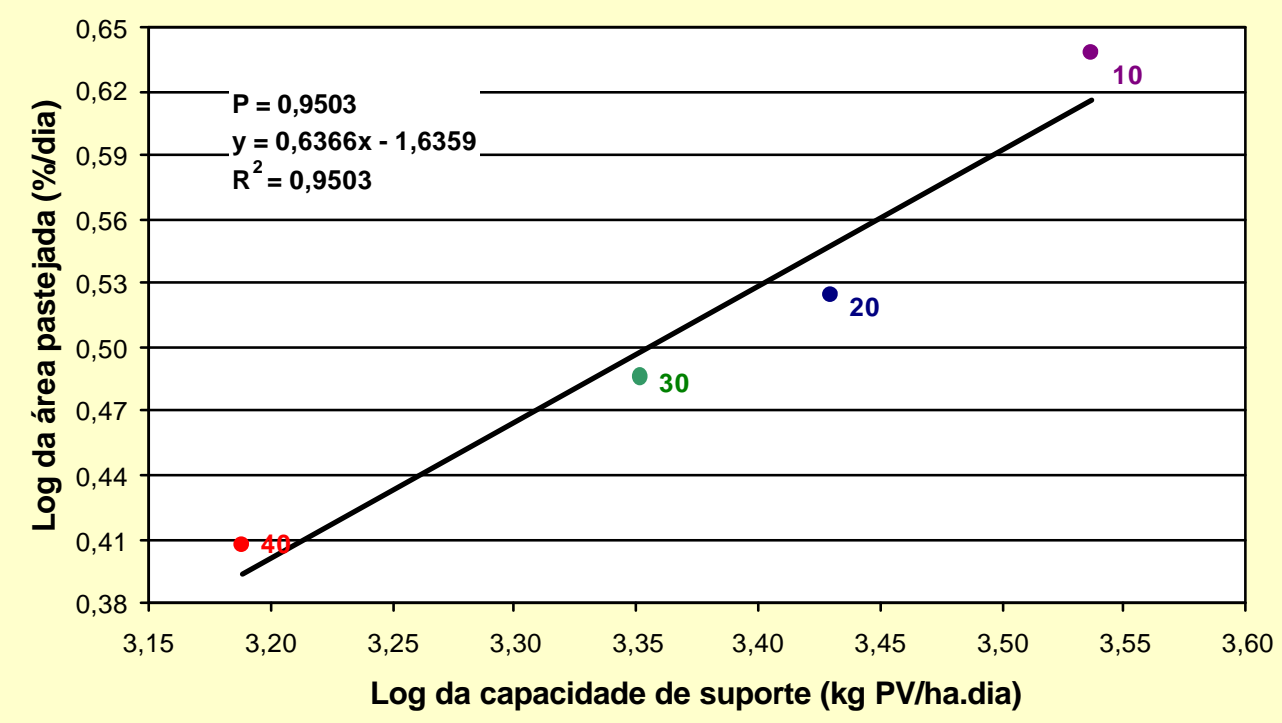

Figura 27 - Relação entre área pastejada por dia (freqüência de desfolhação por folha) e capacidade de suporte (kg PV/ha.dia) em pastos de capim Marandu mantidos em quatro alturas de dossel forrageiro $(\mathrm{cm})$, de novembro de 2001 a fevereiro de 2002. 


\subsubsection{4 - Freqüência de desfolhação por tipo de folha}

Com o objetivo de compreender o processo de desfolhação em folhas de diferentes estádios de desenvolvimento, avaliou-se a freqüência de desfolhação por tipo de folha classificando-as como folhas em expansão, folhas maduras e folhas em senescência (mais de $50 \%$ do limbo foliar verde). Foi constatado efeito de altura do dossel forrageiro ( $P=0,0002)$, mês do ano $(P<0,0001)$ e tipo de folha $(P<0,0001)$. Houve ainda efeito das interações altura:mês $(P=0,0783)$, altura:tipo de folha $(P=$ $0,0118)$ e mês:tipo de folha $(P=0,0003)$. No entanto, não houve efeito da interação tripla altura:mês:tipo de folha $(P=0,9063)$. Os resultados são apresentados nas Tabelas 15, 16 e 17, e nas Figuras 28 e 29.

A freqüência de desfolhação por tipo de folha mostrou uma grande amplitude de respostas, oscilando de 0,008 evento/dia em folhas senescentes para as alturas de 30 e $40 \mathrm{~cm}$, e 0,038 evento/dia nas folhas maduras de pastos mantidos a $10 \mathrm{~cm}$, valores esses equivalentes a 125,0 a 26,3 dias de intervalo entre desfolhações sucessivas, respectivamente (Tabela 15). As folhas senescentes apresentaram a menor freqüência de desfolhação $(0,009$ evento/dia), sendo esse valor cerca de três vezes inferior àqueles observados para folhas maduras $(0,028$ eventos/dia) e folhas em expansão (0,024 evento/dia) (Tabelas 15 e 16). As folhas em expansão apresentaram freqüência de desfolhação pouco inferior àquela de folhas maduras, contrariando o que seria esperado, uma vez que essas folhas localizavam -se nas porções superiores do dossel apresentando, portanto, maior facilidade de acesso para serem desfolhadas. Entretanto, esse fato pode ser explicado quando considera-se que as folhas em expansão estiveram à disposição dos animais para uma eventual desfolhação por um menor período de tempo relativamente ̀̀s folhas maduras (passagem rápida da fase de expansão para madura), razão pela qual poucas delas sofreram uma segunda desfolhação antes de tornarem-se maduras (mudarem de classificação).

A altura do dossel forrageiro influenciou negativamente $(P=0,0002)$ a freqüência de desfolhação por tipo de folha, ou seja, àmedida que o dossel forrageiro foi mantido mais alto menor foi a freqüência de desfolhação por tipo de folha (Figura 28). Como já explicado anteriormente, isso deve ter sido conseqüência da maior massa de forragem nos pastos mais altos (Figura 4), não exigindo que o animal necessitasse 
de uma grande área de pastejo por dia reduzindo, assim, a freqüência de desfolhação de perfilhos individuais.

Tabela 15. Freqüência de desfolhação por tipo de folha (nº de desfolhações/folha.dia) em pastos de capim Marandu mantidos em quatro alturas de dossel forrageiro.

\begin{tabular}{ccccccc}
\hline $\begin{array}{c}\text { TIPO DE } \\
\text { FOLHA }\end{array}$ & 10 & 20 & 30 & 40 & MÉDIA & \multirow{2}{*}{ EPM $^{*}$} \\
\hline Senescente & $0,011^{\mathrm{aC}}$ & $0,007^{\mathrm{aC}}$ & $0,008^{\mathrm{aB}}$ & $0,008^{\mathrm{aB}}$ & $0,009^{\mathrm{C}}$ & 0,0008 \\
Madura & $0,038^{\mathrm{aA}}$ & $0,029^{\mathrm{bA}}$ & $0,024^{\mathrm{CA}}$ & $0,021^{\mathrm{CA}}$ & $0,028^{\mathrm{A}}$ & 0,0008 \\
Expansão & $0,030^{\mathrm{aB}}$ & $0,025^{\mathrm{bB}}$ & $0,022^{\mathrm{bA}}$ & $0,021^{\mathrm{bA}}$ & $0,024^{\mathrm{B}}$ & 0,0008 \\
& & & & & & \\
MÉDIA $^{0,027^{\mathrm{a}}}$ & $0,020^{\mathrm{b}}$ & $0,018^{\mathrm{bc}}$ & $0,016^{\mathrm{C}}$ & & \\
EPM $^{*}$ & 0,0010 & 0,0009 & 0,0009 & 0,0010 & & \\
\hline
\end{tabular}

EPM" - Erro padrao da média

Médias na linha seguidas de mesmas letras minúsculas não diferem entre si $(P \geq 0,10)$

Médias na coluna seguidas de mesmas letras maiúsculas não diferem entre si $(\mathbf{P} \geq 0,10)$

Tabela 16. Freqüência de desfolhação por tipo de folha (no de desfolhações/folha.dia) em pastos de capim Marandu de novembro de 2001 a fevereiro de 2002.

\begin{tabular}{|c|c|c|c|c|c|c|}
\hline \multirow{2}{*}{$\begin{array}{l}\text { TIPO DE } \\
\text { FOLHA }\end{array}$} & \multicolumn{4}{|c|}{ MÊS DE AVALIAÇÃO } & \multirow{2}{*}{ MÉDIA } & \multirow{2}{*}{$\mathrm{EPM}^{*}$} \\
\hline & Novembro & Dezembro & Janeiro & Fevereiro & & \\
\hline Senescente & $0,012^{\mathrm{aC}}$ & $0,008^{\mathrm{bB}}$ & $0,008^{\mathrm{bB}}$ & $0,006^{\mathrm{bB}}$ & $0,009^{C}$ & 0,0008 \\
\hline Madura & $0,035^{\mathrm{aA}}$ & $0,026^{\mathrm{bA}}$ & $0,033^{\mathrm{aA}}$ & $0,017^{\mathrm{CA}}$ & $0,028^{A}$ & 0,0008 \\
\hline Expansão & $0,025^{\mathrm{bB}}$ & $0,025^{\mathrm{bA}}$ & $0,030^{\mathrm{aA}}$ & $0,018^{\mathrm{CA}}$ & $0,024^{\mathrm{B}}$ & 0,0008 \\
\hline MÉDIA & $0,024^{\mathrm{a}}$ & $0,020^{b}$ & $0,024^{\mathrm{a}}$ & $0,014^{c}$ & & \\
\hline EPM $^{*}$ & 0,0010 & 0,0009 & 0,0009 & 0,0009 & & \\
\hline
\end{tabular}

EPM" - Erro padrao da média

Médias na linha seguidas de mesmas letras minúsculas não diferem entre si $(P>0,10)$

Médias na coluna seguidas de mesmas letras maiúsculas não diferem entre si $(\mathbb{R} \geq 0,10)$

Com relação ao mês do ano (Tabela 16 e Figura 29), houve efeito $(P<0,0001)$ sobre a freqüência de desfolhação, sendo essa superior nos meses de novembro de 
2001 e janeiro de 2002, que não diferiram entre si ( $P \geq 0,10)$. O mês de dezembro de 2001 apresentou valores intermediários, enquanto que em fevereiro de 2002 foram observados os menores valores de freqüência de desfolhação por tipo de folha.

O efeito da interação entre altura do dossel forrageiro e mês do ano aqui encontrado ( $P=0,0783$ ) deveu-se ao comportamento observado no mês de novembro de 2001, onde a freqüência de desfolhação por tipo de folha não demonstrou relação inversa com a altura de dossel forrageiro, como observado para todos os outros meses avaliados (Tabela 17). Nesse caso, os valores encontrados para as alturas de 10 e 30 cm diferiram entre si $(P<0,10)$, sendo maior o valor em $10 \mathrm{~cm}$, e não havendo diferenças entre as alturas de 10, 20 e $40 \mathrm{~cm}$ e entre a alturas de 20,30 e $40 \mathrm{~cm}(\mathrm{P} \geq$ $0,10)$.

Tabela 17. Freqüência de desfolhação por tipo de folha ( $n^{\circ}$ de desfolhações/folha.dia) em pastos de capim Marandu mantidos em quatro alturas de dossel forrageiro de novembro de 2001 a fevereiro de 2002.

\begin{tabular}{|c|c|c|c|c|c|c|}
\hline \multirow{2}{*}{ MÊS } & \multicolumn{4}{|c|}{ ALTURA (cm) } & \multirow{2}{*}{ MÉDIA } & \multirow{2}{*}{$\mathrm{EPM}^{*}$} \\
\hline & 10 & 20 & 30 & 40 & & \\
\hline Novembro & $0,026^{\mathrm{aAB}}$ & $0,025^{\mathrm{aA}}$ & $0,021^{\mathrm{bA}}$ & $0,023^{a A}$ & $0,024^{A}$ & 0,0010 \\
\hline Dezembro & $0,029^{\mathrm{aA}}$ & $0,020^{\mathrm{bB}}$ & $0,016^{\mathrm{bcB}}$ & $0,014^{\mathrm{CB}}$ & $0,020^{\mathrm{B}}$ & 0,0009 \\
\hline Janeiro & $0,029^{\mathrm{aA}}$ & $0,022^{\mathrm{bAB}}$ & $0,023^{\mathrm{bA}}$ & $0,022^{\mathrm{bA}}$ & $0,024^{\mathrm{A}}$ & 0,0009 \\
\hline Fevereiro & $0,023^{\mathrm{aB}}$ & $0,014^{\mathrm{bC}}$ & $0,012^{\mathrm{bB}}$ & $0,007^{\mathrm{cC}}$ & $0,014^{C}$ & 0,0009 \\
\hline MÉDIA & $0,027^{\mathrm{a}}$ & $0,020^{b}$ & $0,018^{b c}$ & $0,016^{c}$ & & \\
\hline EPM $^{*}$ & 0,0010 & 0,0009 & 0,0009 & 0,0010 & & \\
\hline
\end{tabular}

O efeito da interação altura:tipo de folha $(P=0,0118)$ pode ser percebido nas folhas senescentes, que não demonstraram sofrer influência $(P \geq 0,10)$ da altura do pasto sobre a freqüência de desfolhação, ao contrário do comportamento observado para as folhas maduras e em expansão (Tabela 15). Esse comportamento diferenciado deveu-se, provavelmente, à seleção dos animais durante o pastejo, rejeitando essa 
porção da planta forrageira. Portanto, o consumo de folhas senescentes parece ser involuntário e ocorre somente quando essas entram acidentalmente no bocado.

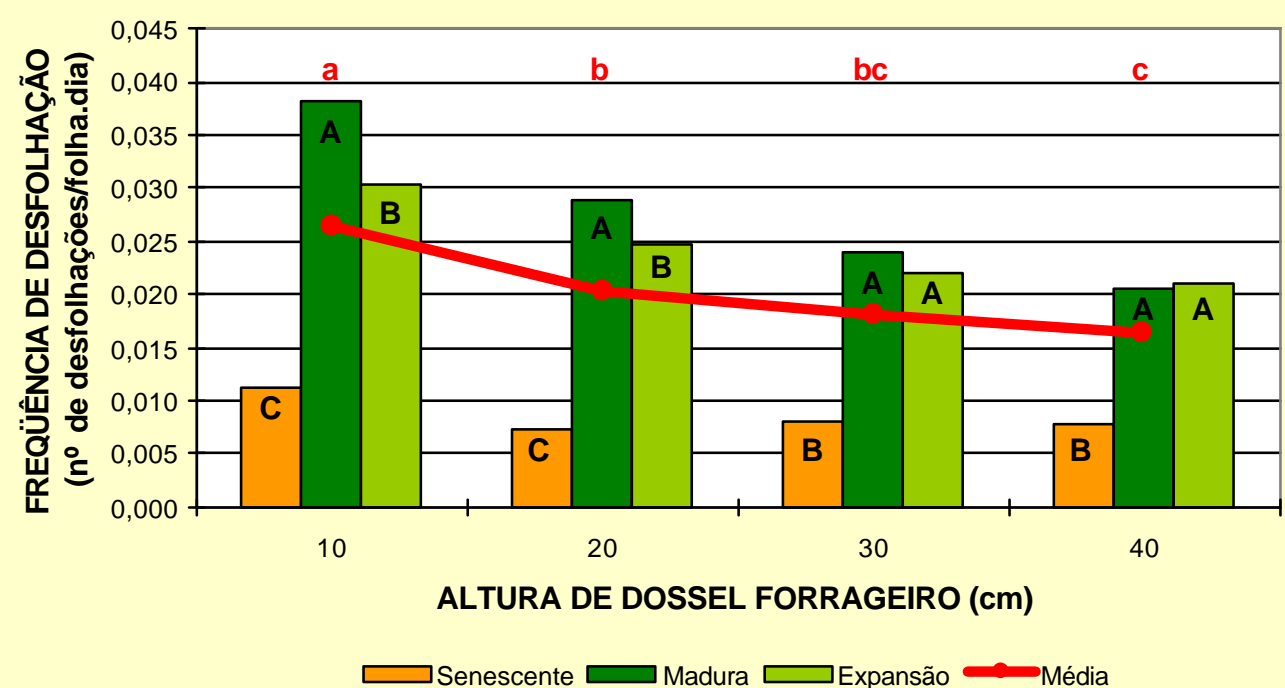

Figura 28 - Freqüência de desfolhação por tipo de folha em pastos de capim Marandu mantidos em quatro alturas de dossel forrageiro $(\mathrm{cm})$.

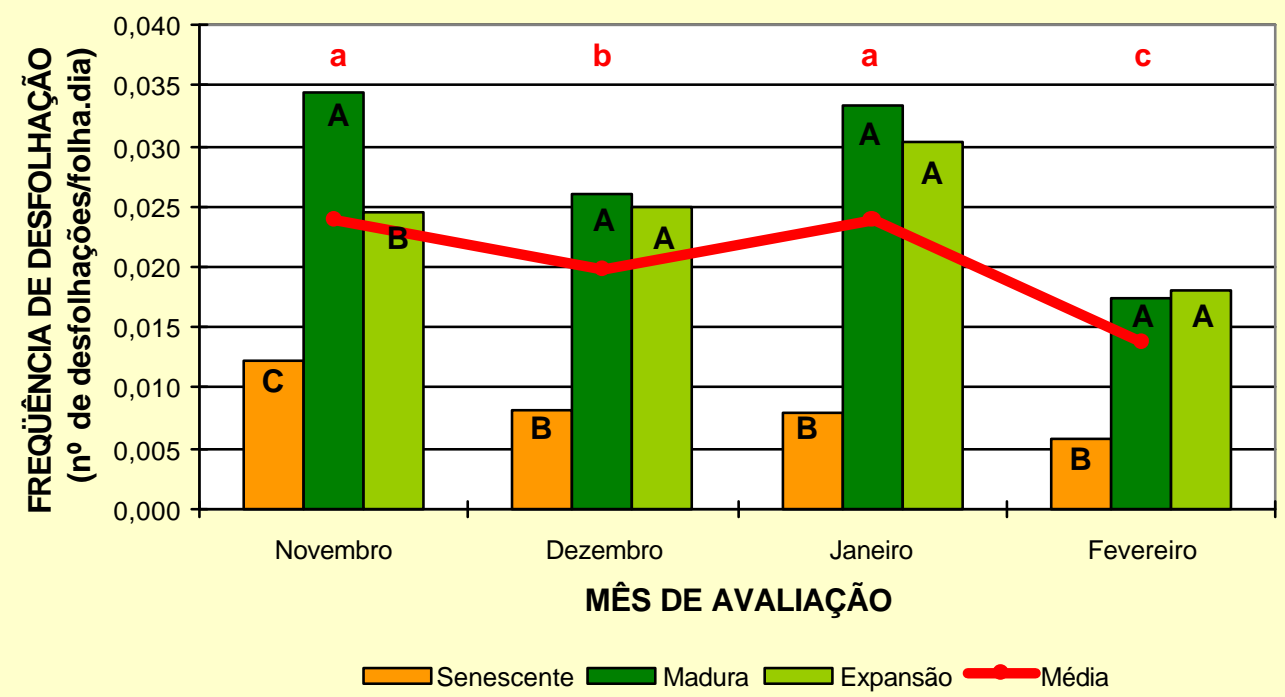

Figura 29 - Freqüência de desfolhação por folha em pastos de capim Marandu de novembro de 2001 a fevereiro de 2002. 
A interação mês:tipo de folha $(P=0,0003)$ também foi gerada a partir do comportamento diverso das folhas senescentes em relação aos demais tipos de folha (Tabela 16). Enquanto os resultados para folhas em expansão e maduras apresentaram oscilações ao longo do período experimental indicando uma freqüência de desfolhação acentuada em janeiro de 2002, condizente com a maior capacidade de suporte utilizada nesse mês, para as folhas em senescência o comportamento foi diferente, revelando valores decrescentes de freqüência de desfolhação ao longo do período experimental.

Os valores encontrados foram também relacionados com os valores de capacidade de suporte (kg PV/ha.dia), na forma logarítmica, a exemplo do apresentado para as demais formas de avaliação de freqüência de desfolhação (Figura 30).

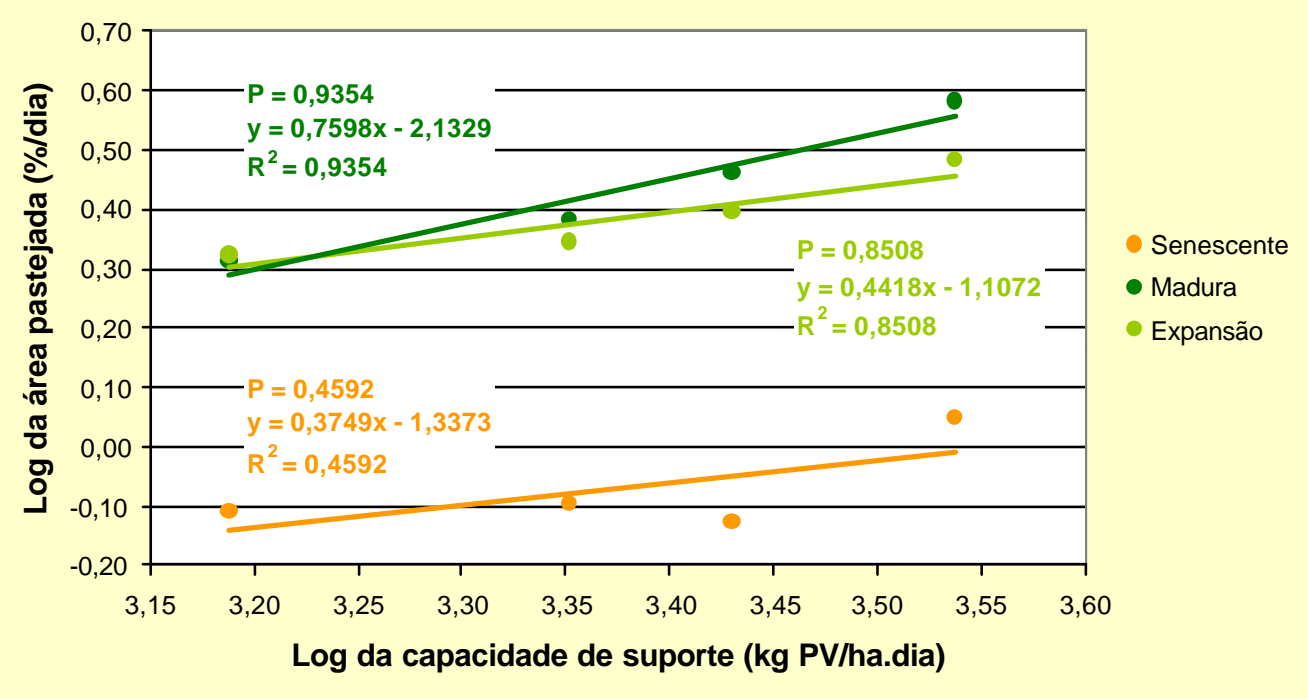

Figura 30 - Relações entre área pastejada por dia (freqüência de desfolhação por tipo de folha) e capacidade de suporte (kg de PV/ha.dia) em pastos de capim Marandu mantidos em quatro alturas de dossel forrageiro $(\mathrm{cm})$, de novembro de 2001 a fevereiro de 2002.

Com base no observado, ficou evidente a associação linear entre a capacidade de suporte e a freqüência de desfolhação para o caso das folhas maduras $\left(R^{2}=\right.$ 
0,9354) e folhas em expansão $\left(R^{2}=0,8508\right)$. No caso das folhas senescentes a associação foi menos evidente $\left(R^{2}=0,4592\right)$, conseqüência da ausência de padrão de variação em freqüência de desfolhação em relação às alturas de dossel forrageiro (Tabela 15) e mês do ano (Tabela 16).

\subsection{2 - Intensidade de desfolhação}

A intensidade de desfolhação, a exemplo do apresentado para freqüência de desfolhação, também foi determinada de formas distintas, considerando-se os efeitos diretos sobre o perfilho estendido, sobre a folha e sobre o tipo de folha.

\subsubsection{1 - Intensidade de desfolhação por perfilho estendido}

Esta é a forma de avaliação comumente utilizada para plantas de clima temperado, particularmente azevém perene, razão pela qual foi utilizada. Houve efeito de altura do dossel forrageiro $(P=0,0099)$, mês do ano $(P=0,0566)$ e interação altura:mês $(P=0,0691)$. Os resultados são apresentados na Tabela 18.

Tabela 18. Intensidade de desfolhação por perfilho estendido (proporção do comprimento removido) em pastos de capim Marandu mantidos em quatro alturas de dossel forrageiro, de novembro de 2001 a fevereiro de 2002.

\begin{tabular}{|c|c|c|c|c|c|c|}
\hline \multirow{2}{*}{ MÊS } & \multicolumn{4}{|c|}{ ALTURA $(\mathrm{cm})$} & \multirow{2}{*}{ MÉDIA } & \multirow{2}{*}{$\mathrm{EPM}^{*}$} \\
\hline & 10 & 20 & 30 & 40 & & \\
\hline Novembro & $0,289^{\mathrm{aAB}}$ & $0,184^{\mathrm{bA}}$ & $0,175^{\mathrm{bAB}}$ & $0,182^{\mathrm{bA}}$ & $0,207^{A B}$ & 0,0173 \\
\hline Dezembro & $0,272^{\mathrm{aB}}$ & $0,188^{\mathrm{bA}}$ & $0,133^{\mathrm{bB}}$ & $0,114^{\mathrm{bB}}$ & $0,177^{\mathrm{B}}$ & 0,0168 \\
\hline Janeiro & $0,286^{\mathrm{aAB}}$ & $0,242^{\mathrm{abA}}$ & $0,212^{\mathrm{abA}}$ & $0,179^{\mathrm{bA}}$ & $0,230^{A}$ & 0,0168 \\
\hline Fevereiro & $0,335^{\mathrm{aA}}$ & $0,183^{\mathrm{bA}}$ & $0,224^{\mathrm{bA}}$ & $0,064^{\mathrm{cB}}$ & $0,202^{A B}$ & 0,0173 \\
\hline MÉDIA & $0,296^{a}$ & $0,199^{b}$ & $0,186^{b}$ & $0,135^{b}$ & & \\
\hline $\mathrm{EPM}^{*}$ & 0,0253 & 0,0250 & 0,0250 & 0,0253 & & \\
\hline
\end{tabular}

EPM* - Erro padrão da média

Médias na linha seguidas de mesmas letras minúsculas não diferem entre si $(P>0,10)$

Médias na coluna seguidas de mesmas letras maiúsculas não diferem entre si $(\mathbb{Z} \geq 0,10)$ 
A intensidade de desfolhação por perfilho estendido variou de $0,114(11,4 \%)$ em dezembro de 2001 nos pastos mantidos a $40 \mathrm{~cm}$ até $0,335(33,5 \%)$ em fevereiro de 2002 nos pastos mantidos a $10 \mathrm{~cm}$. A média geral foi de 0,204 , o que equivale a dizer que $20,4 \%$ do tamanho original do perfilho estendido foi removido a cada desfolhação. São escassos os trabalhos disponíveis na literatura a respeito da intensidade de desfolhação de plantas forrageiras de clima tropical. Os dados existentes correspondem à proporção da altura original do dossel removida em um período de pastejo, ou seja, em seu valor está inclusa a soma das intensidades de todas as desfolhações que aquele perfilho sofreu durante o período de pastejo e não o valor da intensidade de cada desfolhação isolada. Nesse contexto, o trabalho de BRANCIO et al. (2000) com os cultivares Tanzânia, Mombaça e Massai de Panicum maximum revelou uma "intensidade" por perfilho variando de 0,39 a 0,57, tendo como média geral o valor de 0,45 . Esses valores estão maiores que os encontrados para o capim Marandu neste experimento. Entretanto, isso pode ter ocorrido não apenas pela diferença morfológica entre as espécies, mas, principalmente, devido æ̀ diferenças nos protocolos experimentais utilizados. No caso de plantas forrageiras de clima temperado, SENOCK et al. (1993) encontraram para Hilaria mutica (Buckl) Benth. uma intensidade de desfolhação por perfilho estendido variando de 0,258 a 0,459, com uma média geral de 0,355. Esse valor é próximo daqueles encontrados por CARRÈRE et al. (2001) para azevém perene, em que a intensidade de desfolhação de perfilho estendido oscilou de 0,36 a 0,38, e dos 0,34 e 0,33 encontrados por WADE (1991) e MILNE et al. (1982), respectivamente, ambos para azevém perene.

A intensidade de desfolhação de perfilhos em pastos mantidos a $10 \mathrm{~cm}$ foi superior $(P<0,10)$ àquela de pastos mantidos a 20,30 e $40 \mathrm{~cm}$, as quais não diferiram entre si ( $P \geq 0,10)$. CARRÈRE et al. (2001) e HU (1993) verificaram que para o azevém perene a altura de dossel influenciou a intensidade de desfolhação por perfilho estendido, sendo maior a intensidade em pastos mantidos mais baixos. De forma contrária, JAMIESON (1975) não verificou em seu estudo com azevém perene qualquer efeito de altura do dossel sobre a intensidade de desfolhação de perfilhos individuais, permanecendo o valor dessa relativamente constante $(0,35)$.

A maior intensidade de desfolhação nos pastos mantidos a $10 \mathrm{~cm}$ parece ter sido conseqüência de os animais terem que realizar bocados mais próximos ao nível do solo, sendo o limite para colheita da forragem a transição da haste para a lâmina 
foliar, local de diminuição da força necessária para realizar a ruptura da forragem para a execução do bocado. Nos pastos mantidos a 20, 30 e $40 \mathrm{~cm}$ essa ruptura ocorreu ao longo do limbo foliar, distante da haste, caracterizando a menor intensidade de desfolhação. De fato, resultados relativos à estrutura do dossel forrageiro (arranjo espacial) demonstraram que, independentemente da altura do pasto, 50\% da altura do dossel (do topo para baixo) correspondeu a lâminas foliares ${ }^{1}$. Neste caso, $50 \%$ das alturas de 10, 20, 30 e $40 \mathrm{~cm}$ corresponderam a 5, 10, 15 e $20 \mathrm{~cm}$, respectivamente. A profundidade do horizonte de pastejo possui alta correlação com a profundidade do horizonte de folhas (BARTHRAM \& GRANT, 1984), sendo valores inferiores a 8 a 10 cm prejudiciais aos bovinos (HODGSON, 1990). Assim, nas condições deste experimento, os pastos mantidos a $10 \mathrm{~cm}$ representaram uma restrição severa aos animais que tentaram ajustar a redução em consumo ${ }^{3}$ e ganho de peso ${ }^{2}$ através da maior intensidade de desfolhação dos perfilhos.

As variações ocorridas indicam ter havido efeito de mês do ano $(P=0,0566)$ sobre a intensidade de desfolhação por perfilho estendido (Tabela 18). Essa apresentou maiores valores em janeiro de $2002(P<0,10)$, sem diferença em relação a novembro de 2001 e fevereiro de 2002 ( $P \geq 0,10$ ). Já o mês de dezembro de 2001 apresentou os valores mais baixos $(P<0,10)$, também sem diferença em relação a novembro de 2001 e fevereiro de 2002 ( $P \geq 0,10)$. Contraditoriamente, CARRÈRE et al. (2001), em seu estudo com azevém perene, verificaram que a intensidade de desfolhação não sofreu efeito de época do ano, permanecendo relativamente constante. Porém, SENOCK et al. (1993) observaram variações na "intensidade" de desfolhação da Hilaria mutica ao longo do ano, sendo maior no verão que no outono/inverno. Por sua vez, BRANCIO et al. (2000), estudando cultivares de Panicum maximum, constataram que a "intensidade" de desfolhação oscilou conforme o cultivar e a época do ano sem, no entanto, revelar um padrão característico. Esses autores observaram que o maior efeito foi o da altura em pré-pastejo, que quanto maior resultou em valores mais elevados de "intensidade" de desfolhação. Os efeitos aqui observados para o capim Marandu parecem mais relacionados com a capacidade de

\footnotetext{
${ }^{1}$ MOLAN, L. K. (Escola Superior de Agricultura "Luiz de Queiroz", Piracicaba, SP). Estrutura do dosel e interceptação luminosa em pastos de Brachiaria brizantha cv. Marandu (projeto de mestrado em andamento).

${ }^{3}$ SARMENTO, D. O. L. (Escola Superior de Agricultura "Luiz de Queiroz", Piracicaba, SP). Comportamento ingestivo de bovinos de corte em pastos de Brachiaria brizantha cv. Marandu (projeto de mestrado em andamento).

${ }_{2}^{2}$ ANDRADE, F. M. E. (Escola Superior de Agricultura "Luiz de Queiroz", Piracicaba, SP). Valor nutritivo da forragem e desempenho de bovinos de corte em pastos de Brachiaria brizantha cv. Marandu (projeto de mestrado em andamento).
} 
suporte utilizada nos pastos (Figura 21) ao longo do período experimental do que com fatores climáticos. A variação em carga animal deveu-se à variação na taxa de acúmulo de forragem nos diferentes meses avaliados (LUPINACCI, 2002) e a efeitos do manejo aplicado (ajuste em virtude de outras avaliações desenvolvidas na mesma área experimental). Esses resultados corroboram aqueles de RU \& FORTUNE (1999) para trevo subterrâneo (Trifolium subterraneum L.), que revelaram que quanto maior a carga animal adotada maior era a intensidade de desfolhação resultante, a qual variou de $0,45(45 \%)$ a $0,70(70 \%)$.

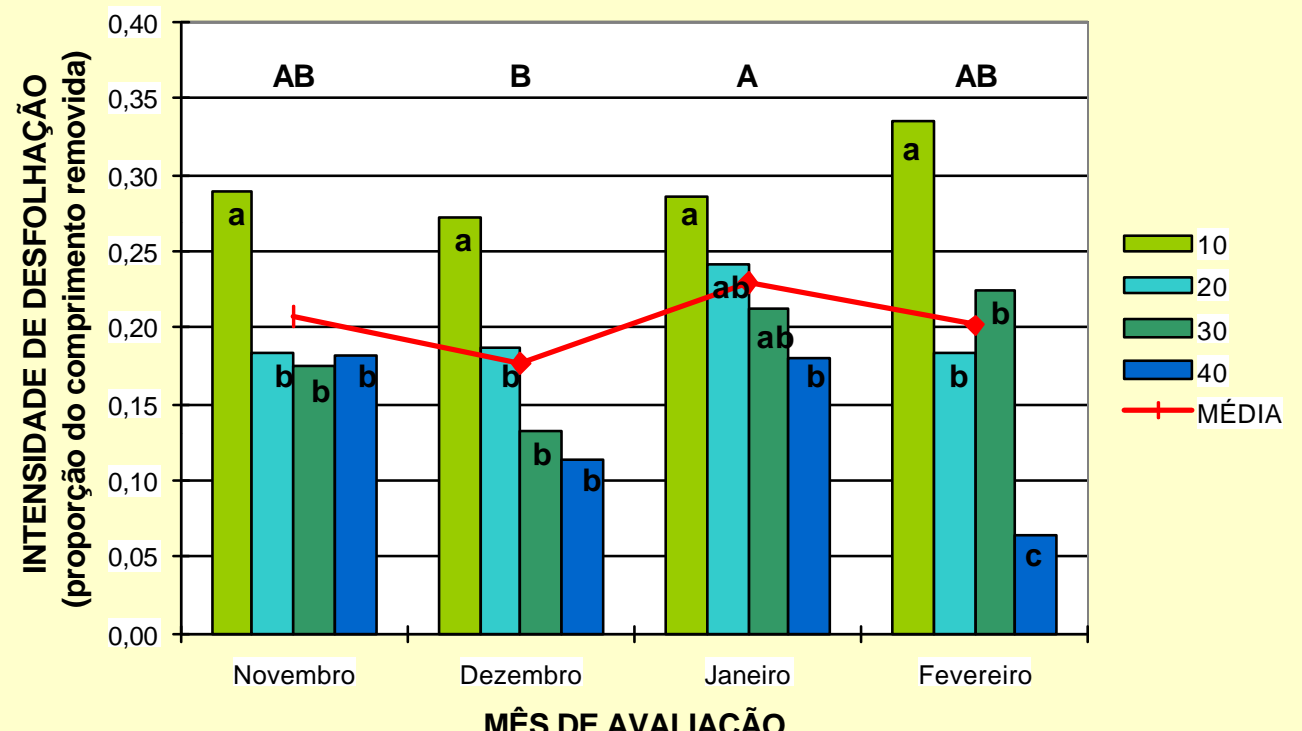

Figura 31 - Intensidade de desfolhação por perfilho estendido em pastos de capim Marandu mantidos em quatro alturas de dossel forrageiro $(\mathrm{cm})$, de novembro de 2001 a fevereiro de 2002.

Houve efeito da interação altura:mês ( $P=0,0691)$, o qual foi percebido em fevereiro de 2002 para altura de $40 \mathrm{~cm}$ quando ocorreu uma queda mais acentuada em intensidade de desfolhação em relação aos demais meses avaliados. A explicação para esse fato poderia estar na maior relação haste:folha derivada do estádio reprodutivo (florescimento) do capim Marandu no mês de fevereiro, em especial nos 
pastos mantidos a $40 \mathrm{~cm}^{1}$. A presença e a altura das hastes possui efeito reconhecidamente limitador da profundidade de pastejo e intensidade de desfolhação de perfilhos por corresponder a uma barreira física (maior resistência dos tecidos) à execução de bocados pelo animal em pastejo (BARTHRAM \& GRANT, 1984).

\subsubsection{2 - Intensidade de desfolhação por folha}

A intensidade de desfolhação por folha contemplou apenas a proporção da redução no comprimento das folhas, independentemente de seu ponto de inserção e da altura do perfilho estudado. Foi detectado efeito de altura do dossel forrageiro $(P=$ $0,0024)$ e de mês do ano $(P=0,0062)$ (Tabela 19). Não houve efeito da interação altura:mês $(P=0,7637)$.

Tabela 19. Intensidade de desfolhação por folha (proporção do comprimento removida) em pastos de capim Marandu mantidos em quatro alturas de dossel forrageiro, de novembro de 2001 a fevereiro de 2002.

\begin{tabular}{|c|c|c|c|c|c|c|}
\hline \multirow{2}{*}{ MÊS } & \multicolumn{4}{|c|}{ ALTURA $(\mathrm{cm})$} & \multirow{2}{*}{ MÉDIA } & \multirow{2}{*}{$\mathrm{EPM}^{*}$} \\
\hline & 10 & 20 & 30 & 40 & & \\
\hline Novembro & 0,699 & 0,675 & 0,603 & 0,649 & $0,657^{\mathrm{C}}$ & 0,0252 \\
\hline Dezembro & 0,769 & 0,673 & 0,609 & 0,622 & $0,668^{\mathrm{BC}}$ & 0,0151 \\
\hline Janeiro & 0,765 & 0,673 & 0,698 & 0,679 & $0,704^{\mathrm{AB}}$ & 0,0118 \\
\hline Fevereiro & 0,806 & 0,712 & 0,704 & 0,711 & $0,733^{A}$ & 0,0188 \\
\hline MÉDIA & $0,760^{\mathrm{a}}$ & $0,683^{b}$ & $0,654^{b}$ & $0,665^{b}$ & & \\
\hline EPM $^{*}$ & 0,0143 & 0,0143 & 0,0143 & 0,0165 & & \\
\hline
\end{tabular}

EPM $^{*}$ - Erro padrão da média

Médias na linha seguidas de mesmas letras minúsculas não diferem entre si $(P>0,10)$

Médias na coluna seguidas de mesmas letras maiúsculas não diferem entre si $(\mathbf{P} \geq 0,10)$

\footnotetext{
${ }^{1}$ MOLAN, L. K. (Escola Superior de Agricultura "Luiz de Queiroz", Piracicaba, SP). Estrutura do dosel e interceptação luminosa em pastos de Brachiaria brizantha cv. Marandu (projeto de mestrado em andamento).
} 
A intensidade de desfolhação por folha oscilou de 0,603 (60,3\%) em novembro de 2001 para o tratamento de $30 \mathrm{~cm}$ de altura do dossel até $0,806(80,6 \%)$ em fevereiro de 2002 para pastos mantidos a $10 \mathrm{~cm}$. A média geral obtida foi de 0,690 $(69,0 \%)$ de intensidade de desfolhação por folha. A literatura aponta, apenas para plantas forrageiras temperadas, valores de intensidade de desfolhação por folha variando de 0,621 a 0,668 para azevém perene (HU, 1993). Trabalhando os dados obtidos por WADE (1991), surgem valores da ordem de 0,68 a 0,70, também para azevém perene. Como observado, os valores encontrados neste estudo com capim Marandu para intensidade de desfolhação por folha são próximos aos verificados para outras plantas forrageiras.

$O$ efeito de altura do dossel forrageiro $(P=0,0024)$ sobre a intensidade de desfolhação por folha indicou que os pastos mantidos a $10 \mathrm{~cm}$ apresentaram comportamento distinto $(P<0,10)$ daquele de pastos mantidos a 20, 30 e $40 \mathrm{~cm}$, os quais não diferiram entre si $(P \geq 0,10$ ) (Figura 32). Essa maior intensidade de desfolhação por folha no relvado mais baixo $(10 \mathrm{~cm})$, assim como ocorreu para a intensidade de desfolhação por perfilho estendido, foi devida à necessidade dos animais tentarem compensar a redução em profundidade do horizonte de folhas, como já discutido anteriormente (item 4.2.2.1).

Como já comentado, independentemente da altura de pasto mantida, os $50 \%$ superiores do dossel foram compostos basicamente por lâminas foliares ${ }^{1}$. Com exceção ao tratamento de $10 \mathrm{~cm}$, a intensidade de desfolhação média por folha foi de $0,667(66,7 \%)$. Assim, multiplicando-se $50 \%$ da altura do pasto (lâminas foliares) por 0,667 obtém-se o valor de $33,3 \%$, ou seja, um terço da altura do pasto foi consistentemente explorada através do pastejo. Esse valor é muito próximo dos $35 \%$ obtidos por WADE (1991) e MAZZANTI \& LEMAIRE (1994) para azevém perene, revelando um elevado grau de similaridade dos padrões de respostas de plantas e animais a manipulação da condição dos pastos, apesar das diferenças morfológicas e fisiológicas existentes entre as espécies estudadas. Esse fato demonstra de forma mais contundente a restrição de consumo imposta aos animais em pastos mantidos mais baixos, razão pela qual esses necessitaram lançar mão de alterações nos

\footnotetext{
${ }^{1}$ MOLAN, L. K. (Escola Superior de Agricultura "Luiz de Queiroz", Piracicaba, SP). Estrutura do dosel e interceptação luminosa em pastos de Brachiaria brizantha cv. Marandu (projeto de mestrado em andamento).
} 
padrões de pastejo das plantas, especialmente freqüência de desfolhação, para compensar reduções potenciais em consumo de nutrientes.

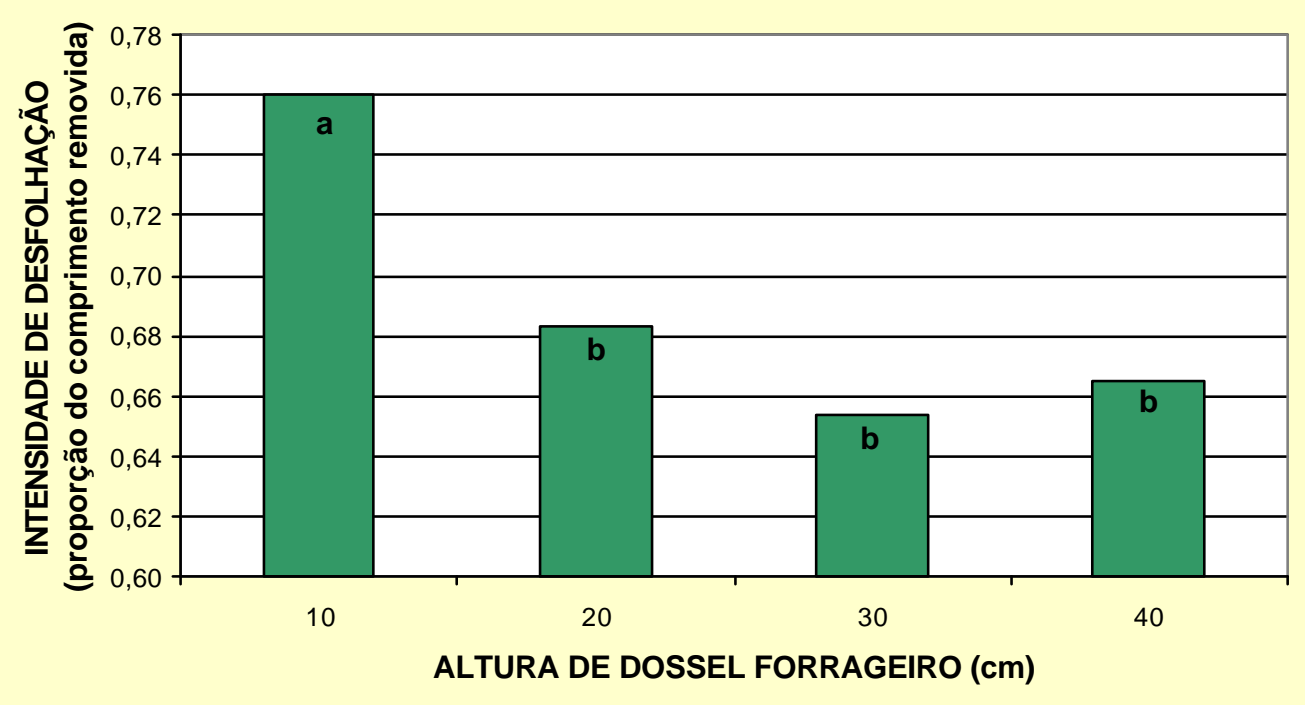

Figura 32 - Intensidade de desfolhação por folha em pastos de capim Marandu mantidos em quatro alturas de dossel forrageiro.

$O$ efeito de mês do ano $(P=0,0062)$ revelou um aumento gradual na intensidade de desfolhação por folha ao longo do período experimental (Figura 33). Uma possível explicação para esse padrão de comportamento dos resultados pode estar relacionada com a passagem das plantas do estádio vegetativo para 0 reprodutivo. Plantas reprodutivas têm reduzida taxa de aparecimento de folhas e aumento da relação haste:folha, o que deve ter resultado no aumento da intensidade de desfolhação das folhas existentes nas plantas, conseqüência do hábito seletivo de animais em pastejo. CUNHA et al. (2000) também verificaram oscilação na intensidade de remoção de folhas para Paspalum atratum (Swallen) cv. BRA-009610, ao longo do período experimental, que foi de novembro de 1997 a maio de 1998, associando esse efeito à adaptação dos animais ao pastejo da planta forrageira e aos processos de preferência e seletividade da dieta. 


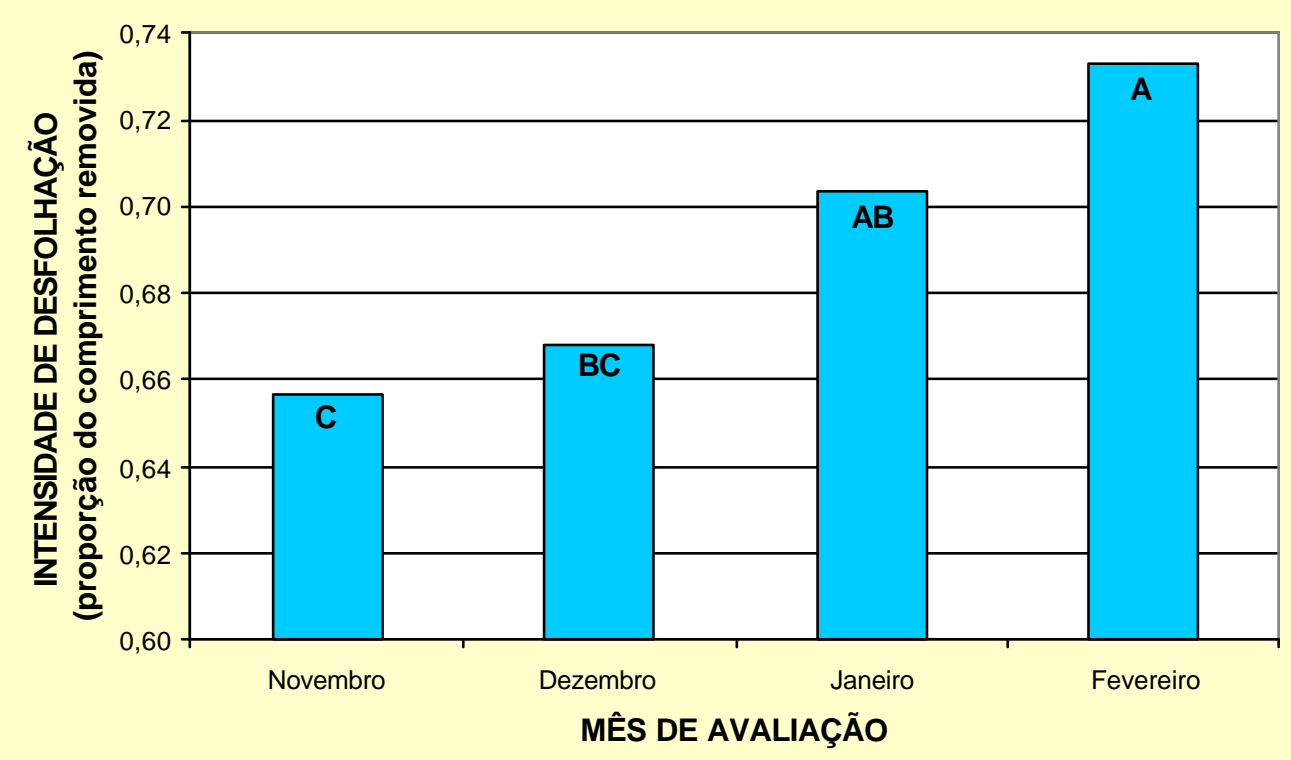

Figura 33 - Intensidade de desfolhação por folha em pastos de capim Marandu, de novembro de 2001 a fevereiro de 2002.

\subsubsection{3 - Intensidade de desfolhação por tipo de folha}

Houve efeito de altura do dossel forrageiro $(P=0,0032)$ e tipo de folha $(P=$ 0,0766), não sendo detectado efeito do mês do ano $(P=0,2660)$. Houve, também, efeito da interação mês:tipo de folha $(P=0,0288)$, não ocorrendo efeito das interações altura:mês $(P=0,7258)$, altura:tipo de folha $(P=0,2428)$ e altura:mês:tipo de folha $(P=$ 0,6025). Os resultados são apresentados nas Tabelas 20 e 21.

Os valores obtidos para intensidade de desfolhação por tipo de folha variaram de $0,504(50,4 \%)$ a $0,790(79,0 \%)$ para as alturas de $40 \mathrm{~cm}$ e $10 \mathrm{~cm}$, respectivamente, ambas para folhas senescentes. A média geral foi de 0,666 (66,6\%). Não foram encontrados na literatura trabalhos similares que quantificassem a intensidade de desfolhação por tipo de folha, impedindo comparações de resultados. Com relação aos valores, aparentemente tudo permaneceu dentro da normalidade, estando os valores aqui demonstrados bastante próximos daqueles apresentados na Tabela 19 (item 4.2.2.2). As diferenças existentes entre os valores médios da Tabela 19 e das Tabelas 
20 e 21 são decorrentes do protocolo de cálculo de médias adotado, com base na média ponderada e na média aritmética, respectivamente.

Tabela 20. Intensidade de desfolhação por tipo de folha (proporção do comprimento removida) em pastos de capim Marandu mantidos em quatro alturas de dossel forrageiro, de novembro de 2001 a fevereiro de 2002.

\begin{tabular}{ccccccc}
\hline $\begin{array}{c}\text { TIPO DE } \\
\text { FOLHA }\end{array}$ & 10 & 20 & 30 & 40 & MÉDIA & EPM $^{*}$ \\
\hline Senescente & 0,790 & 0,604 & 0,618 & 0,504 & $0,629^{\mathrm{B}}$ & 0,0247 \\
Madura & 0,775 & 0,683 & 0,631 & 0,632 & $0,680^{\mathrm{A}}$ & 0,0119 \\
Expansão & 0,752 & 0,690 & 0,655 & 0,663 & $0,690^{\mathrm{A}}$ & 0,0141 \\
& & & & & & \\
MÉDIA & $0,772^{\mathrm{a}}$ & $0,659^{\mathrm{b}}$ & $0,635^{\mathrm{b}}$ & $0,600^{\mathrm{b}}$ & & \\
EPM $^{*}$ & 0,0229 & 0,0258 & 0,0228 & 0,0259 & & \\
\hline
\end{tabular}

EPIVI - Erro padrao da media

Médias na linha seguidas de mesmas letras minúsculas não diferem entre si $(P>0,10)$

Médias na coluna seguidas de mesmas letras maiúsculas não diferem entre si $(\mathbf{P} \geq 0,10)$

Tabela 21. Intensidade de desfolhação por tipo de folha (proporção do comprimento removida) em pastos de capim Marandu de novembro de 2001 a fevereiro de 2002.

\begin{tabular}{ccccccc}
\hline $\begin{array}{c}\text { TIPO DE } \\
\text { FOLHA }\end{array}$ & Novembro & Dezembro & Janeiro & Fevereiro & \multirow{2}{*}{ MÉDIA } & \multirow{2}{*}{ EPM $^{*}$} \\
\hline Senescente & $0,725^{\mathrm{aA}}$ & $0,566^{\mathrm{bB}}$ & $0,616^{\mathrm{bC}}$ & $0,610^{\mathrm{aA}}$ & $0,629^{\mathrm{B}}$ & 0,0247 \\
Madura & $0,659^{\mathrm{abAB}}$ & $0,658^{\mathrm{bA}}$ & $0,699^{\mathrm{aB}}$ & $0,705^{\mathrm{abA}}$ & $0,680^{\mathrm{A}}$ & 0,0119 \\
Expansão & $0,625^{\mathrm{bB}}$ & $0,688^{\mathrm{abA}}$ & $0,744^{\mathrm{aA}}$ & $0,703^{\mathrm{aA}}$ & $0,690^{\mathrm{A}}$ & 0,0141 \\
& & & & & & \\
MÉDIA $^{0,669}$ & 0,638 & 0,686 & 0,673 & & \\
EPM $^{*}$ & 0,0228 & 0,0199 & 0,0180 & 0,0289 & & \\
\hline
\end{tabular}

EPVI"-Erro padrao da meda

Médias na linha seguidas de mesmas letras minúsculas não diferem entre si $(P \geq 0,10)$

Médias na coluna seguidas de mesmas letras maiúsculas não diferem entre si $\left(\mathrm{P}_{\mathbf{Z}} 0,10\right)$ 
Os efeitos de altura do dossel forrageiro sobre a intensidade de desfolhação por tipo de folha $(P=0,0032)$ acompanharam aqueles demonstrados para intensidade de desfolhação por folha. $O$ pasto mantido a uma altura média de $10 \mathrm{~cm}$ apresentou valores superiores $(P<0,10)$ àqueles mantidos a 20,30 e $40 \mathrm{~cm}$, os quais não diferiram entre si $(P \geq 0,10)$ (Figura 34). Não foram detectadas diferenças $(P=0,2660)$ entre os meses avaliados, diferentemente daquilo que foi observado para intensidade de desfolhação por folha (Figura 35). Analisando-se a Tabela 21, é possível perceber que houve uma compensação em intensidade de um tipo de folha em relação aos demais, tornando a média dos tipos de folha para cada um dos meses avaliados relativamente constante. Isso pode ser notado nas diferenças de valores entre os tipos de folhas dos meses de novembro de 2001 e fevereiro de 2002, onde ocorreu uma inversão na seqüência decrescente de valores por tipo de folha. Em novembro de 2001 folhas senescentes apresentaram maior intensidade de desfolhação $(P<0,10)$ que folhas em expansão e folhas maduras que, por sua vez, não diferiram entre si $(P \geq$ $0,10)$. Nos meses de dezembro de 2001 e janeiro de 2002 foram exatamente as folhas senescentes aquelas que apresentaram os menores valores de intensidade de desfolhação $(P<0,10)$ quando comparadas aos demais tipos de folhas (em expansão e maduras). Já em fevereiro de 2002 não foram detectadas diferenças $(P \geq 0,10)$ entre os tipos de folha.

$O$ efeito de tipo de folha $(P=0,0766)$ demonstrou que as folhas em senescência apresentaram uma menor intensidade de desfolhação que as folhas em expansão e maduras $(P<0,10)$, as quais não diferiram entre si $(P \geq 0,10)$. Era esperada alguma redução na intensidade de desfolhação de folhas senescentes em resposta àseletividade dos animais no momento do pastejo. Como demonstrado, essa redução foi pouco expressiva, e os efeitos da seletividade foram mais notáveis sobre a freqüência de desfolhação por tipo de folha. Uma vez introduzida no bocado, a folha senescente acaba por submeter-se a uma intensidade de desfolhação semelhante àquela dos demais tipos de folhas. 


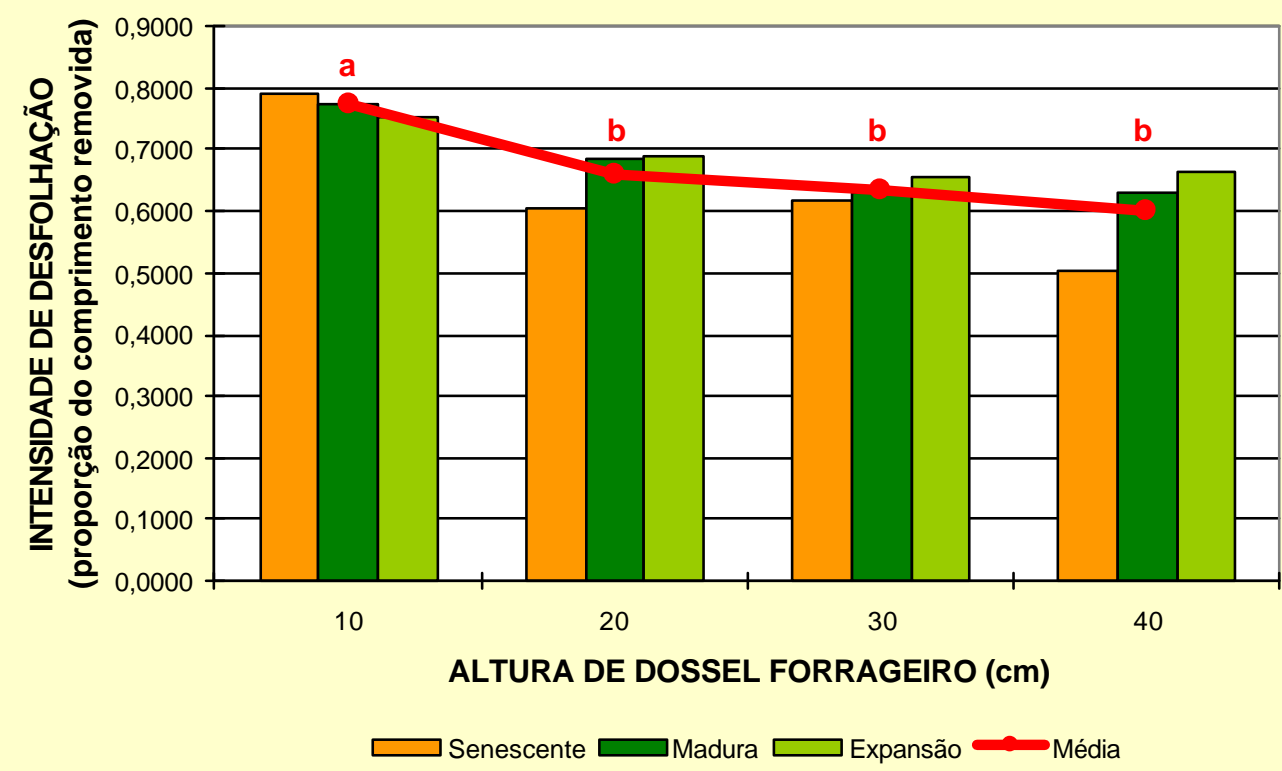

Figura 34 - Intensidade de desfolhação por tipo de folha em pastos de capim Marandu mantidos em quatro alturas de dossel forrageiro $(\mathrm{cm})$, de novembro de 2001 a fevereiro de 2002.

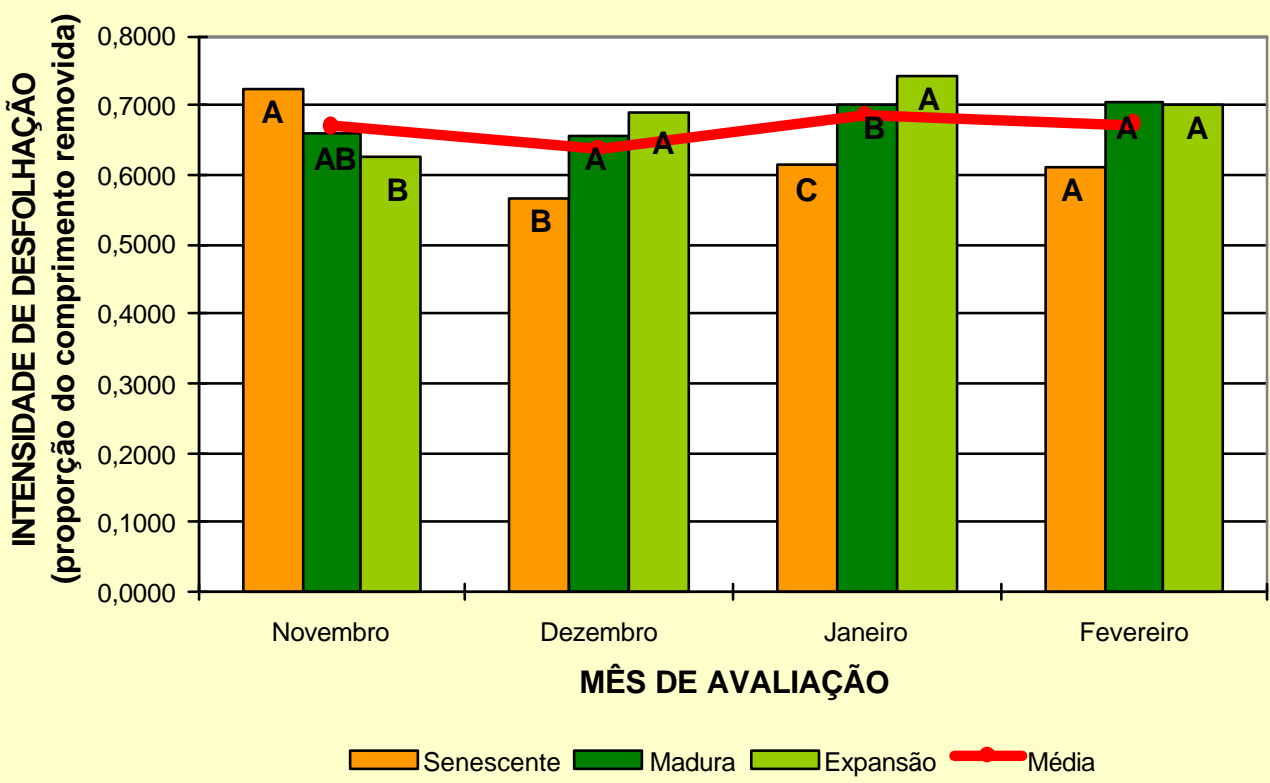

Figura 35 - Intensidade de desfolhação por tipo de folha em pastos de capim Marandu de novembro de 2001 a fevereiro de 2002. 
A interação mês:tipo de folha $(P=0,0288)$ foi conseqüência de uma inversão durante o mês de novembro de 2001 na ordem decrescente de valores de intensidade de desfolhação por tipo de folha. Nesse mês, as folhas senescentes apresentaram elevada intensidade de desfolhação, superior $(P<0,10)$ àquela encontrada para folhas em expansão e similar àde folhas maduras $(P \geq 0,10)$. Em todos os outros meses as folhas senescentes sofreram intensidade de desfolhação inferior $(P<0,10)$ ou similar $(P \geq 0,10)$ aos demais tipos de folha (em expansão e madura).

\subsection{3 - Eficiência de pastejo}

O cálculo da eficiência de pastejo foi elaborado a partir da freqüência e intensidade de desfolhação por folha e da longevidade de folhas expressa em dias. Houve efeito de altura do dossel forrageiro $(P=0,0908)$ e de mês do ano $(P=0,0020)$, como pode ser visualizado na Tabela 22. Não houve efeito da interação altura:mês ( $P$ $=0,6953)$.

Tabela 22. Eficiência de pastejo (\%) em pastos de capim Marandu mantidos em quatro alturas de dossel forrageiro, de novembro de 2001 a fevereiro de 2002.

\begin{tabular}{|c|c|c|c|c|c|c|}
\hline \multirow{2}{*}{ MÊS } & \multicolumn{4}{|c|}{ ALTURA (cm) } & \multirow{2}{*}{ MÉDIA } & \multirow{2}{*}{$\mathrm{EPM}^{*}$} \\
\hline & 10 & 20 & 30 & 40 & & \\
\hline Novembro & 70,6 & 73,4 & 67,3 & 73,6 & $71,2^{\mathrm{B}}$ & 3,64 \\
\hline Dezembro & 79,4 & 70,3 & 60,1 & 50,5 & $65,1^{\mathrm{B}}$ & 3,64 \\
\hline Janeiro & 92,4 & 87,0 & 85,3 & 80,9 & $86,4^{\mathrm{A}}$ & 3,64 \\
\hline Fevereiro & 87,1 & 74,1 & 64,8 & 69,6 & $73,9^{\mathrm{B}}$ & 4,09 \\
\hline MÉDIA & $82,3^{a}$ & $76,2^{\mathrm{ab}}$ & $69,4^{b}$ & $68,7^{\mathrm{b}}$ & & \\
\hline EPM $^{*}$ & 3,64 & 3,64 & 3,64 & 4,09 & & \\
\hline
\end{tabular}

Médias na linha seguidas de mesmas letras minúsculas não diferem entre si $(P \geq 0,10)$

Médias na coluna seguidas de mesmas letras maiúsculas não diferem entre si $(\mathbf{B} \geq 0,10)$ 
Os dados apurados demonstraram que a eficiência de pastejo variou consideravelmente de 50,5\% em dezembro de 2001 nos pastos mantidos a $40 \mathrm{~cm}$ até $92,4 \%$ em janeiro de 2002 nos pastos mantidos a $10 \mathrm{~cm}$. Como eficiência de pastejo média de todo período experimental obteve-se o valor de 74,2\%. Esse valor é similar aos 73\% encontrados por MAZZANTI \& LEMAIRE (1994) para festuca submetida a protocolo experimental análogo ao utilizado neste experimento.

As alturas de dossel forrageiro influenciaram $(P=0,0908)$ a eficiência de pastejo, indicando que àmedida que a altura do pasto foi elevada a eficiência diminuiu (Figura 36). Pastos mantidos a $10 \mathrm{~cm}$ apresentaram eficiência de pastejo superior $(\mathrm{P}<$ $0,10)$ àqueles mantidos a 30 e $40 \mathrm{~cm}$ e similar $(P \geq 0,10)$ àqueles mantidos a $20 \mathrm{~cm}$. Não houve diferença $(P \geq 0,10)$ entre os pastos mantidos a 20, 30 e $40 \mathrm{~cm}$. Como a intensidade de desfolhação por folha variou pouco, a variação em eficiência de pastejo foi função da variação em freqüência de desfolhação, de forma que folhas de perfilhos em pastos mantidos mais altos tiveram um número menor de oportunidades de serem desfolhadas durante seu período de vida, contribuindo para perdas por senescência e baixo aproveitamento da forragem produzida. CAVALCANTE et al. (2002a) associaram a queda em eficiência de pastejo como conseqüência do aumento da altura do pasto às maiores perdas por senescência nos pastos mantidos mais altos. Em experimento com o capim Mombaça, realizado por HERLING et al. (1998), constatou-se que variações na freqüência de desfolhação (caracterizadas por intervalos pré determinados entre pastejos) afetaram a eficiência de pastejo através do efeito que resultaram sobre as perdas de forragem. Nesse estudo, os pastos foram submetidos a dois intervalos entre desfolhações pré-determinados de 35 e 42 dias, correspondentes a freqüências de desfolhação de 0,028 e 0,024 evento/dia, respectivamente. Nos pastos submetidos àmenor freqüência de desfolhação (maior período de descanso) as perdas por senescência foram muito superiores e as perdas no chão pouco inferiores ìs verificadas para os pastos submetidos à maior freqüência. No computo geral, as perdas oriundas dos pastos mantidos sob a menor freqüência de pastejo foram maiores reduzindo, dessa forma, a utilização da forragem produzida e, consequentemente, a eficiência de pastejo. BIRCHAM \& HODGSON (1983), em trabalho clássico com azevém perene, demonstraram que pastos mantidos mais baixos requerem regimes de desfolhação caracterizados por maior freqüência e intensidade 
de desfolhação e, por essa razão, acabam por ter maior eficiência de utilização da forragem produzida pela redução nas perdas por senescência e morte de tecidos.

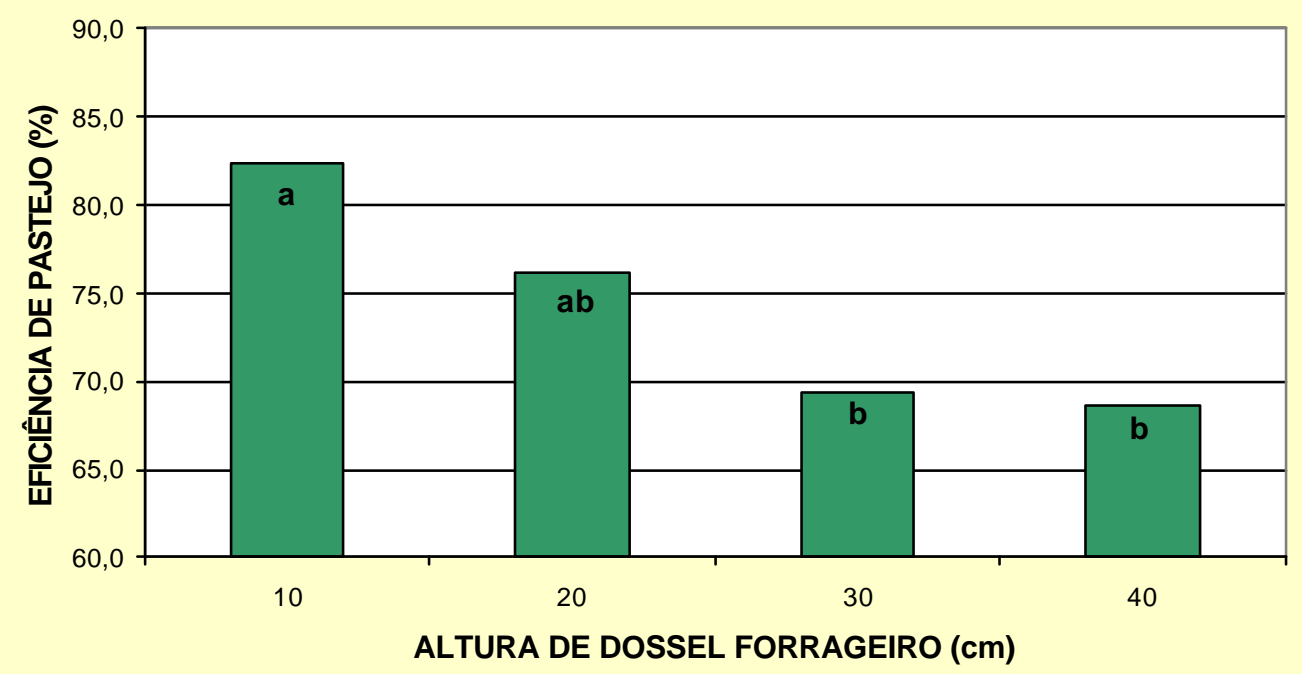

Figura 36 - Eficiência de pastejo em pastos de capim Marandu mantidos em quatro alturas de dossel forrageiro, de novembro de 2001 a fevereiro de 2002.

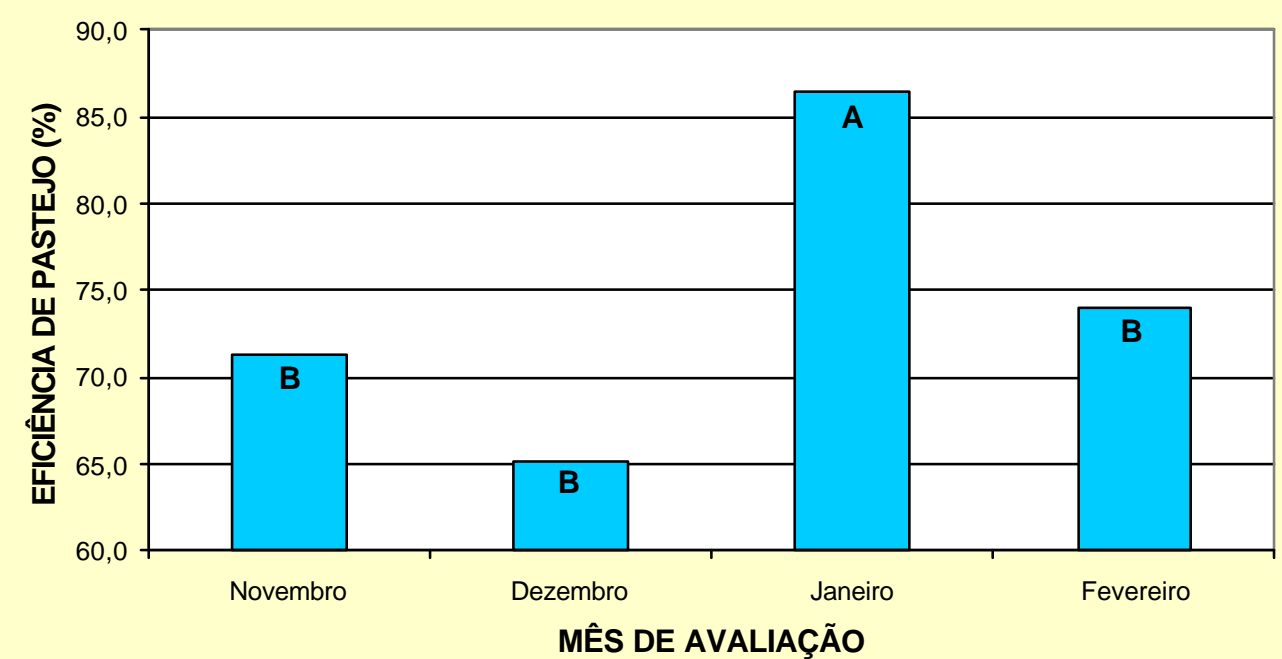

Figura 37 - Eficiência de pastejo em pastos de capim Marandu, de novembro de 2001 a fevereiro de 2002. 
O maior valor de eficiência foi registrado em janeiro de $2002(P<0,10)$, não tendo sido notadas diferenças entre os demais meses $(P \geq 0,10)$ (Figura 37). LOPES et al. (2002), estudando o capim Elefante cultivar Mineiro, observaram que ocorreu variação nas perdas de forragem conforme a época do ano, sendo essas 6,75 vezes maiores no período de fevereiro a maio que no de junho a setembro. Já TORALES et al. (2000), em seu estudo com Paspalum dilatatum (Poir.), verificaram oscilações na eficiência de utilização do pasto conforme a época do ano associando-as a variações na freqüência de desfolhação, exceto para o inverno, época em que essa associação não foi significativa.

No presente estudo, as causas da maior eficiência de pastejo durante o mês de janeiro de 2002 parecem ter derivado de uma combinação de fatores favoráveis: alta freqüência e intensidade de desfolhação e elevada longevidade de folhas. Isso tudo resultou na possibilidade de adotar uma elevada carga animal no período que, inflacionada pela necessidade de maior tempo de permanência dos animais nas parcelas para coleta de dados de outras avaliações concomitantes, originou uma maior eficiência de pastejo. 


\section{CONSIDERAÇÕES FINAIS}

Pastos mantidos a altura de $10 \mathrm{~cm}$, em virtude da melhor qualidade e quantidade de luz a que foram expostos, apresentaram os maiores valores de taxa de aparecimento de folhas e, consequentemente, os menores de filocrono. Para as demais alturas, o efeito de auto-sombreamento acabou por nivelar a TAF e o filocrono num mesmo patamar.

A mudança de estadio fisiológico da planta (vegetativo para reprodutivo) foi a principal responsável pela oscilação negativa nos valores de TAF e positivas no filocrono relacionadas aos meses de avaliação estudados (novembro de 2001 a fevereiro de 2002).

A longevidade de folhas acompanhou as oscilações de filocrono, uma vez que o número de folhas vivas por perfilho permaneceu relativamente constante. Nos pastos mais baixos $(10 \mathrm{~cm})$, foi constatado, ainda, o efeito da maior freqüência e intensidade de desfolhação sobre a longevidade das folhas que, muitas vezes, foram consumidas completamente antes do final de seu ciclo de vida.

A freqüência e intensidade de desfolhação responderam æ̀s variações em altura de dossel forrageiro, sendo maiores em pastos mais baixos que nos mais altos. $A$ elevação na freqüência surge da necessidade dos animais em compensar a menor massa de forragem em pastos mais baixos através do pastejo diário de uma maior área, voltando a pastejar o mesmo ponto em espaço menor de tempo. A limitação física dos bovinos em apreender a forragem em pastos muito baixos, obriga-os a colher as plantas de forma mais severa, inserindo no bocado não apenas parte do limbo foliar, mas toda a lâmina e, inclusive, outras estruturas da planta como hastes e material morto, elevando a intensidade de desfolhação.

A relação linear entre capacidade de suporte do pasto e freqüência de desfolhação foi marcante, e derivada de características morfogênicas como a maior 
TAF e, principalmente, aquelas impostas pelo protocolo de manejo adotado no período experimental.

Folhas senescentes apresentaram intensidade de desfolhação pouco menor que os demais tipos de folhas. Entretanto, a grande diferença no padrão de desfolhação foi conseqüência da reduzida freqüência com que esse tipo de folha era pastejada (3 vezes menos que as outras) e, em geral, de forma acidental misturada æ̀ folhas maduras e em expansão. A menor desfolhação das folhas em expansão em relação æ̀ folhas maduras, deveu-se ao curto tempo em que permanecem nessa categoria, mudando de "status" rapidamente.

A combinação de elevada freqüência e intensidade de desfolhação levou a um maior aproveitamento da forragem produzida nos pastos mantidos em menores alturas, ou seja, elevou a eficiência de pastejo. Nos pastos mais altos, a menor freqüência de desfolhação acabou por elevar as perdas por senescência de tecidos e, com isso, reduzir a eficiência de pastejo. 


\section{CONCLUSÕES}

As características morfogênicas e os padrões de desfolhação do capim Marandu apresentaram comportamento semelhante ao observado para outras plantas forrageiras de clima temperado e tropical.

O estádio fisiológico das plantas influenciou as características morfogênicas, exceção feita apenas ao número de folhas vivas por perfilho.

A altura do dossel forrageiro influencia as características morfogênicas e os padrões de desfolhação de uma pastagem servindo, portanto, como referência prática para definição de estratégias e metas de manejo de plantas forrageiras ao longo do ano.

As metas de condição de pasto (altura) precisam ser relacionadas a objetivos específicos de desempenho e espécie/categoria animal sendo utilizada.

A taxa de lotação possui efeito determinante sobre a eficiência de utilização da forragem produzida mas, no entanto, deve ser conseqüência da manutenção de metas pré-estabelecidas e planejadas de condições de pasto e não referência ou caracterizador de estratégias de manejo do pastejo utilizadas. 


\section{REFERÊNCIAS BIBLIOGRÁFICAS}

ANDRADE, R. P. de. Tecnologia de produção de sementes de espécie do gênero Brachiaria. In: PEIXOTO, A. M.; MOURA, J. C. de; FARIA, V. P. de (Ed.). SIMPÓSIO SOBRE MANEJO DE PASTAGEM - Brachiaria, 11., Piracicaba, 1994. Anais. Piracicaba: FEALQ, 1994, p. 49-72.

ANUALPEC 2002, Anuário da Pecuária Brasileira, Ed. FNP - Consultoria e Comércio, Editora Argos, 392p., São Paulo, SP, 2002.

BARBOSA M. A. A. F.; DAMASCENO, J. C.; CECATO, U.; SAKAGUTI, E. S. Dinâmica do aparecimento, expansão e senescência de folhas em diferentes cultivares de Panicum maximum Jacq. In: REUNIÃO ANUAL DA SOCIEDADE BRASILEIRA DE ZOOTECNIA, 33., Fortaleza, 1996. Anais. Fortaleza: SBZ, 1996. p.101-103.

BARBOSA M. A. A. F.; CECATO, U.; ONORATO, W. M.; YAKADA, F. Y.; BERALDO, J. A.; PETERNELLI, M.; BERTOLASSI, J. R. Efeito do intervalo entre cortes no crescimento de folhas do capim Mombaça (Panicum maximum Jacq. cv. Mombaça) (compact disc). In: REUNIÃO ANUAL DA SOCIEDADE BRASILEIRA DE ZOOTECNIA, 35., Botucatu, 1998. Anais. Botucatu: SBZ, 1998.

BARTHRAM, G. T.; GRANT, S. A. Defoliation of ryegrass-dominated swards by sheep. Grass and Forage Science, v. 39, n. 3, p. 211-219, 1984.

BETTERIDGE, K.; COSTALL, D. A.; HUTCHING, S. M. Ragwort (Senecio jacobaea) controlled by sheep in a hill country bull beef systems. In: NEW ZEALAND PLANT PROTECTION CONFERENCE, 47., Proceedings, 1994. p. 53-57. 
BIRCHAM, J. S.; HODGSON, J. The influence of sward condition on rates of herbage growth and senescence in mixed swards under continuous stocking management. Grass and Forage Science, v. 38, p. 323-331, 1983.

BOOTSMA, A.; ATAJA, A. M.; HODGSON, J. Diet selection by young deer grazing mixed ryegrass/white clover pastures. Proceedings of the New Zealand Grassland Association, v.51, p. 187-190, 1990.

BRÂNCIO, P. A.; NASCIMENTO JÚNIOR, D. do; EUCLIDES, V. P. B.; REGAZZI, A. J.; ALMEIDA, R. G. de; FONSECA, D. M. da. Avaliação de três cultivares de Panicum maximum Jacq. sob pastejo: 1 - Disponibilidade de forragem, altura e profundidade pastejada (compact disc). In: REUNIÃO ANUAL DA SOCIEDADE BRASILEIRA DE ZOOTECNIA, 37., Viçosa, 2000. Anais. Viçosa: SBZ, 2000.

BRASIL. Ministério da Agricultura. Serviço Nacional de Pesquisa Agronômica. Comissão de Solos. Levantamento de reconhecimento dos solos do Estado de São Paulo. Rio de Janeiro. 1960. 634p. (Boletim,12)

BRISKE, D. D. Strategies of plant survival in grazed systems: A functional interpretation. In: HODGSON, J.; ILLIUS, A.W. (Ed.). The ecology and management of grazing systems. London: CAB International, 1996. cap. 2, p. 3767.

BROUGHAM, R. W. Effects of intensity of defoliation on regrowth of pasture. Australian Journal of Agriculture Research, v. 7, p. 377-387, 1956.

BROUGHAM, R. W. Pasture growth rate studies in relation to grazing management. Proceedings of New Zealand Society of Animal Production, v. 17, p. 46-55, 1957.

BROUGHAM, R. W. Effects of intensity of light by the foliage of pure and mixes stands of pasture plants. Australian Journal of Agriculture Research, v. 9, p 39-52, 1958. 
BROUGHAM, R. W. The effects of frequency and intensity of grazing on the productivity of pasture of short rotation ryegrass and red and white clover. New Zealand Journal of Agricultural Research, v. 2, p. 1232-1248, 1959.

BROUGHAM, R. W. The effects of frequent hard grazings at different times of the year on the productivity and species yields of grass-clover pasture. New Zealand Journal of Agricultural Research, v. 3, p. 125-136, 1960.

BULLOCK, J. M. Plant competition and population dynamics. In: HODGSON, J.; ILLIUS, A. W. (Ed.). The ecology and management of grazing systems. London: CAB International, 1996. cap. 3, p. 69-100.

BURLINSON, A. J.; HODGSON, J.; ILLIUS, A. W. Sward canopy structure and the bite dimensions and bite weight of grazing sheep. Grass and Forage Science, v. 46, p. 29-38, 1991.

CARRÈRE, P.; LOUAULT, F.; CARVALHO, P. C. de F.; LAFARGE, M.; SOUSSANA, J. $F$. How does the vertical and horizontal structure of a perennial ryegrass and white clover sward influence grazing? Grass and Forage Science, v. 56, p. 118-130, 2001.

CARVALHO, D. D. de. Leaf morphogenesis and tillering behaviour in single plantas and simulated swards of guinea grass (Panicum maximum Jacq.) cultivars. Palmerston North, New Zealand, 2002. 186p. Thesis (PhD) - Massey University.

CARVALHO, D. D. de; DAMASCENO, J. C. Aspectos fisiológicos do capim-Elefante cv. Roxo-de-Botucatu. I. Taxa de aparecimento, expansão e senescência de folhas. In: REUNIÃO ANUAL DA SOCIEDADE BRASILEIRA DE ZOOTECNIA, 33., Fortaleza, 1996. Anais. Fortaleza: SBZ, 1996. p. 4-5. 
CAVALCANTE, M. A. B.; GOMIDE, J. A.; PEREIRA, O. G.; GARCIA, R.; GRASSELI, L. C. Acúmulo de forragem em relvado de Brachiaria decumbens cv. Basilisk sob pastejo, em diferentes alturas (compact disc). In: REUNIÃO ANUAL DA SOCIEDADE BRASILEIRA DE ZOOTECNIA, 39., Recife, 2002. Anais. Recife: SBZ, 2002a.

CAVAlCANTE, M. A. B.; GOMIDE, J. A.; PEREIRA, O. G.; GARCIA, R.; GRASSELI, L. C. Características morfogênicas e estruturais do relvado de Brachiaria decumbens cv. Basilisk sob pastejo, em diferentes alturas (compact disc). In: REUNIÃO ANUAL DA SOCIEDADE BRASILEIRA DE ZOOTECNIA, 39., Recife, 2002. Anais. Recife: SBZ, 2002b.

CHACON, E.; STOBBS, T. H. Influence of progressive defoliation of a grass sward on the eating behavior of cattle. Australian Journal of Agricultural Research, v. 27, p. 709-727, 1976.

CHAPMAN, D. F.; LEMAIRE, G. Morphogenic and structural determinants of plant regrowth after defoliation. In: BAKER, M. J. (Ed.). Grasslands for our world. Wellington: SIR, 1993. cap. 3, p. 55-64.

COMBELLAS, J.; HODGSON, J. Herbage intake and milk production by grazing dairy cows. 1. The effects of variation in herbage mass and daily herbage allowance in a short-term trial. Grass and Forage Science, n. 34, p. 209-214, 1979.

COOPER, J. P.; WILSON, D. Variation in photosynthetic rate in Lolium. In: INTERNATIONAL GRASSLAND CONGRESS, 11., Surfers Paradise, 1970. Proceedings. Santa Lucia: University of Queensland Press, 1970. p.522-527.

CORSI, M.; BALSALOBRE, M. A.; SANTOS, P. M.; DA SILVA, S. C. Bases para o estabelecimento do manejo de pastagens de braquiária. In: SIMPÓSIO SOBRE MANEJO DE PASTAGEM, 11., Piracicaba, 1994. Anais. Piracicaba: FEALQ, 1994. p. 249-266. 
COSGROVE, G. Animal grazing behaviour and forage intake. In: GOMIDE, J. A. INTERNATIONAL SYMPOSIUM OF ANIMAL PRODUCTION UNDER GRAZING, Viçosa, 1997. Anais. Viçosa: Universidade Federal de Viçosa, 1997, p. 59-80.

CUNHA, M. A. D. da; LEITE, G. G.; DIOGO, J. M. da S.; VIVALDI, L. J. Características morfológicas do paspalum atratum BRA009610 submetido ao pastejo rotacionado: II - Lâmina viva, lâmina removida e senescência de folhas (compact disc). In: REUNIÃO ANUAL DA SOCIEDADE BRASILEIRA DE ZOOTECNIA, 37., Viçosa, 2000. Anais. Viçosa: SBZ, 2000.

DA SILVA, S. C.; PEDREIRA, C. G. S. Princípios de ecologia aplicados ao manejo de pastagem. In: SIMPÓSIO SOBRE ECOSSISTEMAS DE PASTAGENS, 3., Jaboticabal, 1997. Anais. Jaboticabal : FUNEP, 1997., p. 1-62.

DA SILVA, S. C.; SBRISSIA, A. F. A planta forrageira no sistema de produção. In: SIMPÓSIO SOBRE MANEJO DE PASTAGEM - A PLANTA FORRAGEIRA NO SISTEMA DE PRODUÇÃO, 17., Piracicaba, 2000. Anais. Piracicaba: FEALQ, 2000. p. 3-21.

DEINUM, B.; SULASTRI, R. D.; ZEINAB, M. H. J. MAASSEN, A. Effects of light intensity on growth, anatomy and forage quality of two tropical grasses (Brachiaria brizantha and Panicum maximum var. trichoglume). Netherlands Journal of Agricultural Science, v. 44, p. 111-124, 1996.

EMPRESA BRASILEIRA DE PESQUISA AGROPECUÁRIA. Sistema brasileiro de classificação de solos. Brasília: EMBRAPA Produção de Informação, 1999. 412p.

FAGUNDES, J. L. Efeito de intensidades de pastejo sobre o índice de área foliar, interceptação luminosa e acúmulo de forragem em pastagens de Cynodon spp. Piracicaba, 1999. 59p. Dissertação (Mestrado) - Escola Superior de Agricultura "Luiz de Queiroz", Universidade de São Paulo.

FAO, Food and Agricultural Organization. http://www.fao.org. (19 set. 2002). 
FARIA, V. P.; PEDREIRA, C. G. S.; SANTOS, F. A. P. Evolução do uso de pastagens para bovinos. In: SIMPÓSIO SOBRE MANEJO DE PASTAGEM, 13., Piracicaba, 1996. Anais. Piracicaba: FEALQ, 1996, p. 1-15.

FENGRUI, L. The effects of frequency of cutting and cultivar on the period of leaf expansion in White clover grown in mixed swards. Grass and Forage Science, n. 55, p. 280-284, 2000.

FRANK, A. B.; HOFMAN, L. Light quality and stem numbers in cool-season forage grasses. Crop Science. v. 34, n. 2, p. 468-473, 1994.

FULKERSON, W. J.; SLACK, K. Leaf number as a criterion for determining defoliation time for Lolium perenne, 2 - Effect of defoliation frequency and height. Grass and Forage Science, n. 50, v. 1, p.16-20, 1995.

GHISI, O. M. A.; PEDREIRA, J. V. S. Características agronômicas das principais Brachiaria spp. In: PEDREIRA, J. V. S.; MEIRELLES, N. M. F. (Ed.). ENCONTRO SOBRE CAPINS DO GÊNERO Brachiaria, Nova Odessa, 1986. Anais. Nova Odessa, SP: Instituto de Zootecnia, 1987. p. 19-58.

GOMIDE J. A. Morfogênese e análise de crescimento de gramíneas tropicais. In: SIMPÓSIO INTERNACIONAL SOBRE PRODUÇÃO ANIMAL EM PASTEJO, Viçosa, 1997, Anais. Viçosa: UFV, 1997. p. 97-115.

GOMIDE J. A.; GOMIDE, C. A. M. Fundamentos e estratégia do manejo de pastagens. In: SIMPÓSIO DE PRODUÇÃO DE GADO DE CORTE, I., Viçosa, 1999, Anais, Viçosa, 1999. p. 179-200.

GOMIDE, C. A. M.; GOMIDE, J. A.; PACCIULLO, D. S. C. Fluxo de tecidos em Brachiaria decumbens (compact disc). In: REUNIÃO ANUAL DA SOCIEDADE BRASILEIRA DE ZOOTECNIA, 34., Juiz de Fora, 1997. Anais. Juiz de Fora: SBZ, 1997. 
GOMIDE, C. A. de M.; PACIULLO, D. S. C.; GRASSELLI, L. C. P.; GOMIDE, J. A. Efeito da adubação sobre a morfogênese de gramíneas tropicais (compact disc). In: REUNIÃO ANUAL DA SOCIEDADE BRASILEIRA DE ZOOTECNIA, 35., Botucatu, 1998. Anais. Botucatu: SBZ, 1998.

GRANT, S. A.; KING, J. Grazing management and pasture production: the importance of sward morphological adaptations and canopy photosynthesis. In: HILL FARMING RESEARCH ORGANISATION, Biennal report. 1983. p. 119-129.

GRANT, S. A.; MARRIOTT, C. A. Detailed studies of grazer swards - techniques and conclusions. Journal of Agricultural Science, v. 122, p. 1-6, 1994.

GRANT, S. A.; BARTHRAM, G. T.; TORVELL, L.; KING, J.; ELSDON, D. A. Comparison of herbage production under continuous stocking and intermittent grazing. Grass and Forage Science, v. 43, n. 5, p. 29-39, 1988.

HERLING, V. R.; PIAZZA, C.; JANTALIA, C. P.; SUDA, C. H.; LUZ, P. H. de C.; LIMA, C. G. de. Efeito do período de descanso e da matéria seca residual no capim Mombaça (Panicum maximum, Jacq.): 2 - Perdas de matéria seca (compact disc). In: REUNIÃO ANUAL DA SOCIEDADE BRASILEIRA DE ZOOTECNIA, 35., Botucatu, 1998. Anais. Botucatu: SBZ, 1998.

HODEN, A.; PEYRAUD, J. L.; MULLER, A.; DELABY, L.; FAVERDIN, P. Simplified rotational grazing management of dairy cows: effects of rates of stocking and concentrate. Journal of Agricultural Science, v. 116, p. 417-428, 1991.

HODGSON, J. The frequency of defoliation of individual tillers in a set-stocked sward. Journal of the British Grassland Science, v. 27, p. 258-263, 1966.

HODGSON, J. Variations in the surface characteristics of the sward and short-term rate of herbage intake by calves and lambs. Grass and Forage Science, v. 36, p. 4957, 1981. 
HODGSON, J. Sward conditions, herbage allowance and animal production: an evaluation of research results. In: Proceddings of New Zealand Grassland Society, v. 44, p. 99-104, 1984.

HODGSON, J. Grazing management: Science into pratice. New York: John Wiley; Longman Scientific and Technical, Longman, 1990. 203p.

HODGSON, J.; WADE, M. H. Grazing management and herbage production. Proceedings of British Grassland Society of the Winter Meeting, Grazing, sward production and livestock output, p. 1-12, 1978.

HODGSON, J.; RODRIGUEZ CAPRILES, J. M.; FENLON, J. S. The influence of sward characteristics on the herbage intake of grazing calves. Journal of Agricultural Science, v. 89, p. 743-750, 1977.

HODGSON, J.; BIRCHAM, J. S.; GRANT, S. A.; KING, J. The influence of cutting and grazing management on herbage growth and utilization. In: PLANT PHYSIOLOGY AND HERBAGE PRODUCTION, Occasional Symposium, 13., Belfast, 1981. Anais. Belfast: British Grassland Society, 1981, p. 51-62.

HU, Y. A comparative study of defoliation in Holcus lanatus and Lolium perenne pastures grazed by sheep. Palmerston North, 1993. 85p. Thesis (Master) - Massey University.

HUGHES, R.; JACKSON, D. K. Impact of grazing management on sward survival. Journal of the British Grassland Society, v. 26, p. 76, 1974.

IBGE, Instituto Brasileiro de Geografia e Estatística. http:/www.IBGE.gov.br. (20 set. 2002).

ILLIUS, A. W.; GORDON, I. J.; MILNE, J. D.; WRIGHT, W. Costs and benefits of foraging on grasses varying in canopy structure and resistance to defoliation. Functional Ecology, v. 9, p. 894-903, 1995. 
JACQUES, W. A. Yorkshire fog (Holcus lanatus L.) It's potential as a pasture species. Procedings os the New Zealand Grassland Association, v. 35: p. 249-257, 1974.

JAMIESON, W. S. Studies on the herbage intake and grazing behaviour of cattle and sheep. Reading, 1975, Thesis (Ph.D) - University of Reading.

JEWISS, O. R.; Tillering in grasses: Its significance and control. Journal of the British Grassland Society, v. 72, p. 65-82, 1972.

LACA, E. A.; UNGAR, E. D.; SELIGMAN, N.; DEMMENT, M. W. Effects of sward height and bulk density on bite dimensions of cattle grazing homogeneous swards. Grass and Forage Science, v. 47, p. 91-102, 1992.

LANGER, R. H. M. Tillering in herbage grasses. Herbage Abstracts, v. 33, n. 3, p. 141-148, 1963.

LANGER, R. H. M. How grasses grow. London: The Institute of Biology's Studies, 1972. 60p. (Studies in Biology, v. 34).

LAWLOR, D. W. Photosynthesis, productivity and environment. Journal Experimental Botany, v. 46 (especial issue), p. 1449-1461, 1995.

LEAFE, E. L.; PARSONS, A. J. Physiology of growth of grazed sward. In: INTERNATIONAL GRASSLAND CONGRESS, 14., Lexington, Kentucky, 1981. Proceedings. Boulder: Westview Press, 1983, p. 403-406.

LEMAIRE, G.; AGNUSDEI, M. Leaf tissue turn over and efficiency of herbage utilization. In: SIMPÓSIO INTERNACIONAL "GRASSLAND ECOPHYSIOLOGY AND ECOLOGY”, 1., Curitiba, 1999. Anais. Curitiba: UFPR, 1999, p.165-183. 
LEMAIRE, G.; CHAPMAN, D. Tissue flows in grazed plant communities. In: HODGSON, J.; ILLIUS A. W. (Ed.). The ecology and management of grazing systems. London: CAB International, 1996. cap. 1, p. 3-36.

LOPES, F. C. F.; DERESZ, F.; RODRIGUEZ, N. M.; AROEIRA, L. J. M.; MATOS, L. L. de; VITTORI, A. Disponibilidade e perdas de matéria seca em pastagem de capimElefante manejado em pastejo rotativo com diferentes períodos de descanso (compact disc). In: REUNIÃO ANUAL DA SOCIEDADE BRASILEIRA DE ZOOTECNIA, 39., Recife, 2002. Anais. Recife: SBZ, 2002.

LUCENA, J. E. C.; SANTOS, M. V. F. dos; FERREIRA, M. de A.; SANTOS, D. C. dos; FERREIRA, R. L. C.; DUBEUX JÚNIOR, J. C. B.; CAVALCANTI FILHO, L. F. M. Composição florística, altura e disponibilidade de forragem em pastagem de Brachiaria decumbens, Stapf. sob pastejo na zona da mata de Pernambuco (compact disc). In: REUNIÃO ANUAL DA SOCIEDADE BRASILEIRA DE ZOOTECNIA, 39., Recife, 2002. Anais. Recife: SBZ, 2002.

LUPINACCI, A. V. Resenvas orgânicas, índice de área foliar e produção de forragem em Brachiaria brizantha $c v$. Marandu. submetida a intensidades de pastejo por bovinos de corte. Piracicaba, 2002. 160p. Dissertação (Mestrado) - Escola Superior de Agricultura "Luiz de Queiroz", Universidade de São Paulo.

MACEDO, M. C. M. Pastagens no ecossitema cerrados: pesquisa para o desenvolvimento sustentável. In: SIMPÓSIO SOBRE PASTAGENS NOS ECOSSISTEMAS BRASILEIROS: PESQUISA PARA O DESENVOLVIMENTO SUSTENTÁVEL, 1., Brasília, 1995. Anais. Brasília, SBZ, 1995. p. 28-62.

MATTHEW, C.; LEMAIRE, G.; SACKVILLE HAMILTON, N. R.; HERNÁNDEZ GARRAY, A. A modified self-thinning equation to describe size/density relationships for defoliated swards. Annals of Botany, v. 76, p. 579-587, 1995. 
MATTHEW, C.; ASSUERO, S. G.; BLACK, C. K.; SACKVILLE HAMILTON, N. R. Tiller dynamics of grazed swards. In: SIMPÓSIO INTERNACIONAL "GRASSLAND ECOPHYSIOLOGY AND GRAZING ECOLOGY”, Curitiba, 1999. Anais. Curitiba: UFPR/UFRGS, 1999. p.109-133.

MAXWELL, T. J.; TREACHER, T. T. Decision rules for grassland management. In: EFFICIENT SHEEP PRODUCTION FROM GRASS. POLLOTT, G. E. (Ed.). In: OCCASIONAL SYMPOSIUM OF BRITISH GRASSLAND SOCIETY, 21., 1987. Anais. Britsh Grassland Society, 1987. p. 67-78.

MAZZANTI, A.; LEMAIRE, G. Effects of nitrogen fertilization on the herbage production of tall fescue swards grazed continuously with sheep. 1. Consumption and efficiency of herbage utilization. Grass and Forage Science, v. 49, p. 352-359, 1994.

MILNE, J. A.; HODGSON, J.; THOMPSON, R.; SOUTER, W. G.; BARTHRAM, G. T. The diet ingested by sheep grazing swards differing in white clover and perennial ryegrass content. Grass and Forage Science, v. 37, p. 209-218, 1982.

MOTT, G. O. Grazing pressure and the measurement of pasture production. In: INTERNATIONAL GRASSLAND CONGRESS, 8., Berkshire, 1960. Proceedings. Oxford: Alden Press, 1961. p. 606-611.

NABINGER, C. Eficiência do uso de pastagens: disponibilidade e perdas de forragem. In: SIMPÓSIO SOBRE MANEJO DA PASTAGEM, 14., Piracicaba, 1997. Anais. Piracicaba: FEALQ, 1997. p. 213-251.

NUNES, S. G.; BOOK, A.; PENTEADO, M. I. DE O.; GOMES, D. T. Brachiaria brizantha cv. Marandu. 2.ed. Campo Grande: EMBRAPA CNPGC, 1985. 31p. (EMBRAPA-CNPGC, Documentos, 21). 
OLIVEIRA, M. A. de; PEREIRA, O. G.; GARCIA, R.; HUAMAN, C. A. M. Y; SILVEIRA P. R. da. Morfogênese de folhas do Tifton 85 (Cynodon spp.) em diferentes idades de rebrota (compact disc). In: REUNIÃO ANUAL DA SOCIEDADE BRASILEIRA DE ZOOTECNIA, 35., Botucatu, 1998. Anais. Botucatu: SBZ, 1998.

OMETO, J. C. Registros e estimativas dos parâmetros meteorológicos da região de Piracicaba, SP. Piracicaba: FEALQ, 1989. 76p.

PACIULlO, D. S. C.; DeRESZ, F.; COELHO, A. D. F.; NOBRE, M. do S. A. Características morfogênicas e estruturais e acúmulo de forragem em pastagem de capim-Elefante manejado sob pastejo rotativo em diferentes estações do ano (compact disc). In: REUNIÃO ANUAL DA SOCIEDADE BRASILEIRA DE ZOOTECNIA, 39., Recife, 2002. Anais. Recife: SBZ, 2002.

PARSONS, A. J. The effects of season and management on the growth of swards. In: JONES, M. B.; LAZEMBY A. (Ed.). The grass crop: the physiological basis of production. London: Chapman and Hall, 1988. p.129-177.

PARSONS, A. J. Exploiting resource capture - grassland. In: MONTEITH, J. L.; UNSWORTH, M. H. (Ed.). Resource capture in crops. Nottingham: University Press, 1994. p. 315-322.

PARSONS, A. J.; CHAPMAN, D. F. Principles of grass growth and pasture utilization In: Grass for Dairy cattle. Berkshire; CAB, cap. 4, 1988.

PARSONS, A. J.; PENNING, P. D. The effects of duraction of regrowth on photossynthesis, leaf death, and the average rate of growth in a rotationally grazed sward. Grass and Forage Science, v. 43, p. 15-27, 1988.

PARSONS, A. J.; LEAFE, E. L.; COLLET, B.; STILES, W. The physiology of grass production under grazing I. Characteristics os leaf and canopy photosynthesis of continuously grazed swards. Journal of Applied Ecology, v. 20, p.117-126, 1983a. 
PARSONS, A. J.; LeAFE, E. L.; COLLET, B.; PENNING, P. D.; LEWIS, J. The physiology of grass production under grazing II. Photosyntesis, crop growth and animal intake of continuously-grazed swards. Journal of Applied Ecology, v. 20, p. 127-139, 1983b.

PARSONS, A. J.; JOHNSON, J. R.; HARVEY, A. Use of a model to optimize the interaction between frequency and severity of intermittent defoliation and to provide a fundamental comparison of the continuos and intermittent defoliation of grass. Grass and Forage Science, v. 43, p. 49-59, 1988.

PARSONS, A. J.; PENNING, P. D.; LOCKYER, D. R. Uptake, cucling and fate of nitrogen in grass-clover swards continuously grazed by sheep. Journal of Agricultural Science, v. 116, p. 47-61, 1991a.

PARSONS, A. J.; HARVEY, A.; WOLEDGE, J. Plant-animal interactions in a continuously grazed mixture. I. Differences in the physiology of leaves of grass and clover. Journal of Applied Ecology, v. 28, p. 619-634, 1991 b.

PENNING, P. D.; PARSONS, A. J.; ORR, R. J.; TREACHER, T. T. Intake and behaviour responses by sheep to changes in sward characteristics under continuous stocking. Grass and Forage Science, v. 46, p. 15-28, 1991.

PINTO, L. F de M. Dinâmica do acúmulo de matéria seca em pastagens de Cynodom spp. Piracicaba, 2000. 124p. Dissertação (Mestrado) - Escola Superior de Agricultura "Luiz de Queiroz", Universidade de São Paulo.

PINTO, J. C.; GOMIDE, J. A.; MAESTRI, M.; LOPES, N. F. Crescimento de folhas de gramíneas forrageiras tropicais, cultivadas em vasos, com duas doses de nitrogênio. Revista de Sociedade Brasileira de Zootecnia, v. 23, p. 327-332, 1994. 
POPPI, D. P.; HUGHES, T. P.; L'HUILLIER, P. J. Intake of pasture by grazing ruminants. In: LIVESTOCK FEEDING ON PASTURE. New Zealand Society of Animal Production, Occasional Symposium, 10., Hamilton, 1987. Hamilton: Lincoln College, 1987, p. 55-63.

RAIJ, B. VAN; CANTARELLA, H.; QUAGGIO, J. A.; FURLANI, A. M. C. (Ed.). Recomendações de adubação e calagem para o Estado de São Paulo. 2. ed. Campinas: Instituto Agronômico; Fundação IAC, 1996. 258p. (Boletim Técnico, 100).

RENVOIZE, S. A.; CLAYTON, W. D.; SKABUYE, C. H. Morfología, taxonomía y distribución natural de Brachiaria (Trin.) Griseb. In: MILLES, J. W.; MASS, B. L.; VALLE, B. C. (Ed.). Brachiaria: biología, agronomía y mejoramiento. Cali: CIAT; Campo Grande: EMBRAPA CNPGC, 1998. cap. 1, p. 1-15.

RU, Y. J; FORTUNE, J. A. Effects of grazing intensity and cultivar on morphology, phenology, and nutritive value of subterranean clover during the growing season. Australian Journal of Agricultural Research, v. 50, p. 1191-1201, 1999.

SALISBURY, F. B.; ROSS, C. W. Plant physiology. 4.ed. Wadsworth: 1992. 682p.

SANTOS, P. M. Estudo de características de Panicum maximum (Jacq.) cvs. Tanzânia e Mombaça para estabelecer seu manejo. Piracicaba, 1997. 62p. Dissertação (Mestrado) - Escola Superior de Agricultura "Luiz de Queiroz", Universidade de São Paulo.

SANTOS, P. M.; CORSI, M.; BALSALOBRE, M. A. A. Efeito da freqüência de pastejo e da época do ano sobre a produção e a qualidade em Panicum maximum cvs. Tanzânia e Mombaça. Revista Brasileira de Zootecnia, v. 28, n. 2, p. 244-249, 1999. 
SANTOS FILHO, L. F. Seed production: perspective from the Brazilian private sector. In: MILES, J. W.; MASS, B. L.; VALLE, C. B. (Ed.). Brachiaria biology, agronomy, and improvement. Cali: CIAT; Campo Grande: EMBRAPA-CNPGC, 1996, cap. 9 , p. 141-146.

SAS INSTITUTE. http://sasdocs.ucdavis.edu. (20 abril 2002).

SBRISSIA, A. F. Compensação tamanho/densidade populacional de perfilhos em pastagens de Cynodom spp. Piracicaba, 2000. 80p. Dissertação (Mestrado) Escola Superior de Agricultura "Luiz de Queiroz", Universidade de São Paulo.

SBRISSIA, A. F.; DA SILVA, S. C. O ecossistema de pastagens e a produção animal. In: MATTOS, W. R. S. (Ed.). A produção animal na Visão dos Brasileiros, SBZ, Piracicaba: SBZ, p.731-754, 927p, 2001.

SBRISSIA, A. F.; DA SILVA, S. C.; CARVALHO, C. A. B.; CARNEVALLI, R. A.; PINTO, L. F. M.; FAGUNDES, J. L.; PEDREIRA, C. G. S. Tiller size/population density compensation in Coastcross grazed swards. Scientia Agrícola, v. 58, n. 4, p.655665, 2001.

SENOCK, R. S.; ANDERSON, D. M.; MURRAY, L. W.; DONART, G. B. Tobosa tiller defoliation patterns under rotational and continuous stocking. Journal of Range Management, v. 46, n. 6, p. 500-505, 1993.

SILSBURY, J. H. Leaf growth in pasture grasses. Tropical Grasslands. v. 4, p. 17-36, 1970.

SILVA, D. S. da; QUEIROZ FILHO, J. L.; SANTOS, E. A. dos; NASCIMENTO, I. S. do. Aspectos produtivos e morfológicos do capim-Elefante (Pennisetum purpureum Schum.) cv. Roxo submetido àsalinidade. In: REUNIÃO ANUAL DA SOCIEDADE BRASILEIRA DE ZOOTECNIA, 33., Fortaleza, 1996. Anais. Fortaleza: SBZ, 1996. p. 65-67. 
SKERMAN, P. J.; RIVEROS, F. Gramíneas tropicales. Roma: FAO, 1992. 832p. (Colección FAO: Producción y protección vegetal, 23).

SKINNER, R. H.; NELSON, C. J. Effect of tiller trimming on phyllochron and tillering regulation during tall fescue development. Crop Science. v. 34, n. 5, p. 1267-1273, 1994.

SKINNER, R. H.; NELSON, C. J. Elongation of the grass leaf and its relationship to the phylochron. Crop Science. v. 34, n. 1, p. 4-10, 1995.

SOARES FILHO, C. V. Recomendações de espécies e variedades de Brachiaria para diferentes condições In: PEIXOTO, A. M.; MOURA, J. C. de; FARIA, V. P. de (Ed.). SIMPÓSIO SOBRE MANEJO DE PASTAGEM - Brachiaria, 11., Piracicaba, SP, 1994. Anais. Piracicaba: FEALQ, 1994, p. 25-49.

STOBBS, T. H. The effect of plant structure on the intake of tropical pastures. III, Influence of fertilizer nitrogen on the size of bite harvested by Jersey cows grazing Setaria anceps cv. Kazungula Swards. Australian Journal of Agricultural Research. v. 26, n. 6, p. 997-1007, 1975.

TORALES, A. T. A.; ACOSTA, G. L.; DEREGiBuS, V. A.; MOAURO, P. M. Effects os grazind frequency on the production, nutritive value, herbage utilization, and structure of a Paspalum dilatatum sward. New Zealand Journal of Agricultural Research, v. 43. p. 467-472, 2000.

USP/ESALQ - Departamento de Ciências Exatas. http://www.ce.esalq.usp.br (20 abril 2002).

VAN ESBROECK, G. A.; HUSSEY, M. A.; SANDERSON, M. A. Leaf appearance rate and final leaf number of switchgrass cultivars. Crop Science, v. 37, p. 864-870, 1997. 
WADE, M. H. Factors affecting the availability of vegetative lolium perenne to grazing dairy cows with special reference to sward characteristics, stocking rate and grazing method. Saint Gilles, 1991. 89p. These (Docteur) - Universite de Rennes.

WADE, M. H.; BAKER, R. D. Defoliation in set-stocked grazing systems. Grass and Forage Science, v. 34, p. 73-74, 1979.

WADE, M. H.; PEYRAUD, J. L.; LEMAIRE, G.; CAMERON, E. A. The dynamics of daily area and depth of grazing and herbage intake of cows in a five day paddock system. In: INTERNATIONAL GRASSLAND CONGRESS, 16., Nice, 1989, Proceedings. Nice: 1989. p. 1111-1112.

WILHEM, D.; McMASTER, G. S. Importance of the phyllocron in studying development and growth in grasses. Crop Science. v. 35, p. 1-3, 1995.

WILMAN, D.; MARES MARTINS, V. M. Senescence and death of herbage during periods of regrowth in ryegrass and red and white clover, and the effect of applied nitrogen. Journal of Applied Ecology, v. 14, p. 615-620, 1977.

WOLEDGE, J. The effect of shading and cutting treatments on the photosynthetic rate of ryegrass leaves. Annals of Botany, v. 41, n. 176, p. 1279-1286,1977.

ZARROUGH, K. M.; WILSON, C. J.; SLEPER, D. A. Inter-relationship between rates of leaf appearance and tillering in selected tall fescue populations. Crop Science. v. 24, n. 4, p. 565-568, 1984. 